University of Nebraska - Lincoln

DigitalCommons@University of Nebraska - Lincoln

Agronomy \& Horticulture -- Faculty Publications

Agronomy and Horticulture Department

10-1948

\title{
Prairies and Pastures of the Dissected Loess Plains of Central Nebraska
}

J. E. Weaver

University of Nebraska-Lincoln

W. E. Bruner

Follow this and additional works at: https://digitalcommons.unl.edu/agronomyfacpub

Part of the Plant Sciences Commons

Weaver, J. E. and Bruner, W. E., "Prairies and Pastures of the Dissected Loess Plains of Central Nebraska" (1948). Agronomy \& Horticulture -- Faculty Publications. 495.

https://digitalcommons.unl.edu/agronomyfacpub/495

This Article is brought to you for free and open access by the Agronomy and Horticulture Department at DigitalCommons@University of Nebraska - Lincoln. It has been accepted for inclusion in Agronomy \& Horticulture -Faculty Publications by an authorized administrator of DigitalCommons@University of Nebraska - Lincoln. 


\title{
PRAIRIES AND PASTURES OF THE DISSECTED LOESS PLAINS OF CENTRAL NEBRASKA*
}

\author{
J. E. Weaver \\ University of Nebraska \\ AND \\ W. E. Bruner \\ State Teachers College \\ Kearney, Nebraska
}

* Contribution No. 152 from the Department of Botany, University of Nebraska. This study was aidem by a grant from the University Research Council, University of Nebraska. 


\section{TABLE OF CONTENTS}

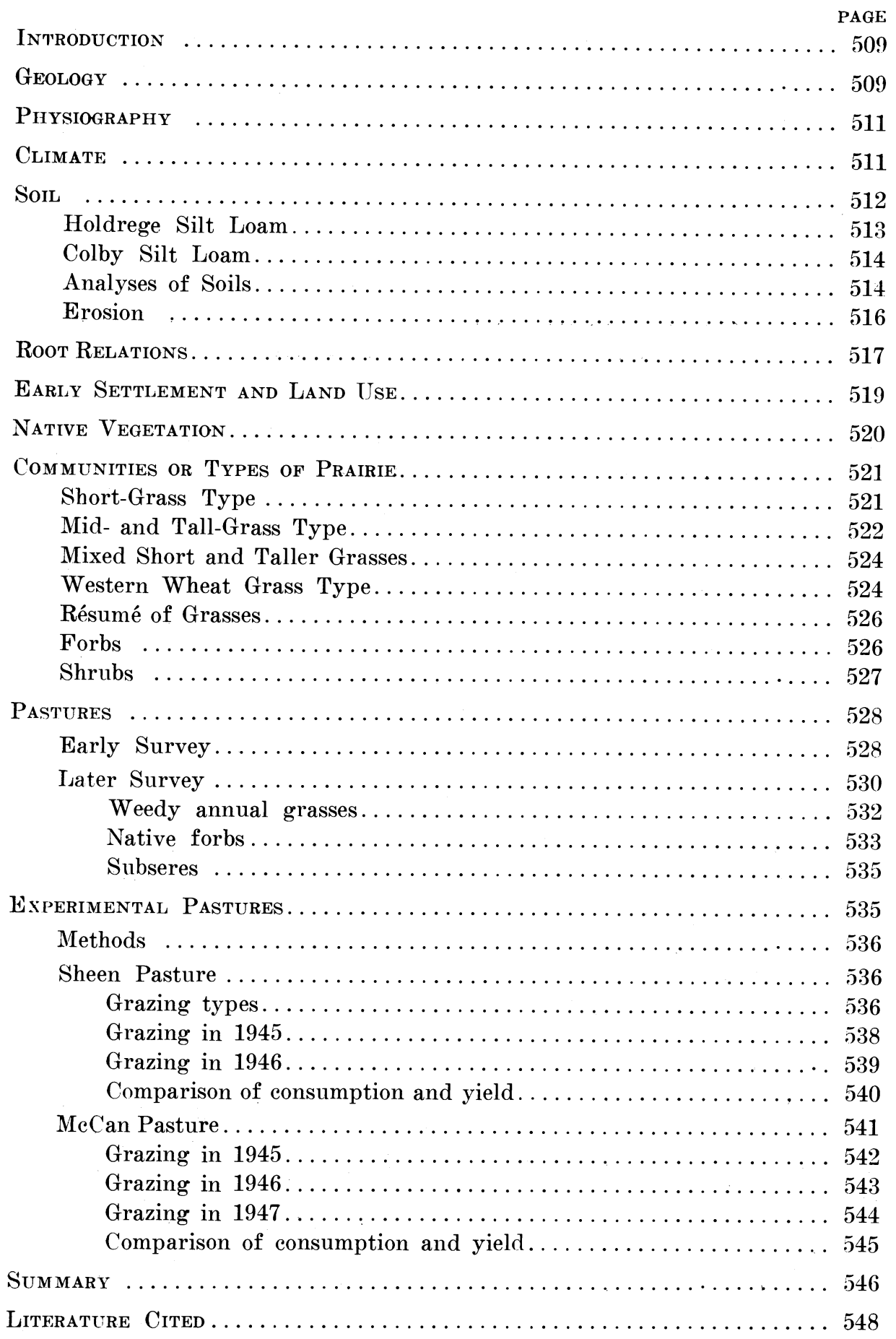




\section{PRAIRIES AND PASTURES OF THE DISSECTED LOESS PLAINS OF CFNTRAL NEBRASKA*}

\section{INTRODUCTION}

Lying north of the great southward bend of the Platte River in central Nebraska but southeast of the sandhills, there are several thousand square miles of rugged uplands known as loess bluffs. They are quite unlike the sandhills with their typical cover, largely of postclimax tall grasses. They also differ widely from the Nebraska plain eastward and southeastward where mid-grass or true prairie clothes the level or slightly undulating land. The vegetation of the sandhills has been studied only recently, by modern methods, in its relation to soils and climate (Tolstead 1942). The mixed prairie southward has undergone extended examination throughout a complete drought cycle (Albertson 1937; Albertson \& Weaver 1942; Weaver \& Albertson 1943, 1944). But the excellent cover of grasses and forbs of the mixed prairie, which clothes and protects the highly erosive loess bluffs and furnishes sustenance for thousands of cattle, has thus far not attracted the attention of an ecologist.

This preliminary survey is eoncerned with soil and aerial environment of the abundant undisturbed native regetation, and its composition and behavior in the extensive range lands. It also includes a 3-year study of grazing types, of grazing patterns throughout the season, and of forage yield and forage consumption in experimental pastures.

\section{GEOLOGY}

The area between Broken Bow, Ord, Grand Island, Kearney, and Lexington encompasses parts of two principal physiographic regions, the Central $\mathrm{Ne}$ braska Dissected Loess Plains and the Platte River Lowland-Terraceland regions. However, most of the area lies within the Dissected Loess Plains region which is separated into subregions by relatively narrow strips of terracelands and lowlands along the South Loup and Middle Loup River valleys and minol drainages which are largely tributary to the Loup Rivers and in part tributary to the Platte River.

The Central Nebraska Dissected Loess Plains grade transitionally into the Sandhills region to the north and northwest. They are bounded by the Platte River Lowland and Terraceland region on the south and merge with the Loess and Drift Hill regions eastward and northeastward beyond the limits of the area under discussion.

The area is developed principally on mantlerock materials of Pleistocene age with occasional small areas, principally along valley sides, where the limy sandstones of the Ogallala formation of Pliocene age are exposed.
A period of general uplift and extensive erosion followed the deposition of the Ogallala sediments, and the Ogallala formation was carved into hills and valleys of considerable relief, approaching 150 feet or more in places. The post-Pliocene drainage pattern appears to be distinct from the present drainage pattern.

In early Pleistocene time the lower parts of the post-Pliocene valleys were filled with alluvial sands and gravels capped with silts. These sediments were deposited during the time when the first continental glaciation (the Nebraskan) invaded the eastern part of Nebraska and when the earliest mountain glaciation was an important factor in the mountainous areas to the west and northwest of Nebraska. This glacial epoch was followed by a period of weathering and soil development which in turn was followed by a second major glaciation (the Kansan).

During early Kansan time a second cycle of erosion and sedimentation began. It was similar to the preceding (Nebraskan) cycle but was probably along a somewhat different and changing drainage pattern. This channeling and filling removed some of the materials deposited in Nebraskan time and filled the Kansan valleys up to levels generally above those of the Nebraskan sedimentation. The Kansan glacial epoch was followed by a second period of weathering and soil development. Thus, a constructional topography was built which tended toward decreasing the general relief of the area and toward the establishment of a high sloping plain surface, which is reflected today in the high plain remnants which are scattered throughout this topographic region.

The trend during middle and later Pleistocene time in this region has been toward greater down-cutting and lesser valley filling, which is more closely related to the present drainage pattern, with the development of narrower and successively lower valleys. Moreover, the interfluve areas received relatively thick mantles of wind-blown dust known as loess, much of it being blown up from the alluvial flats along the through valleys of the region. There were two principal periods and one or more minor ones of loess accumulation separated by periods of weathering and soil development. Near important source areas, the loess accumulated rapidly and formed relatively thick deposits. Farther from important source areas, the loess accumulated more slowly, it formed thinner deposits and underwent more weathering during accumulation. ${ }^{1}$

It has been concluded by Condra, Reed, and Gor-

1 The writers are indebted to Mr. E. C. Reed, Associate Di. rector of the Nebraska Conservation and Survey Division, for this geological description. 
don (1947) that comparatively little loess was formed in Nebraska when sediments were being released from mountain glaciers and fresh till sheets. Lugn (1935) has shown that the Sandhill region has released much Tertiary and Pleistocene loess-forming material which was blown prevailingly eastward and southeastward contributing directly or indirectly to Loveland and Peorian deposits in a broad area east of the sandhills. Condra, Reed, and Gordon (1947) state that Nebraska loess was developed from various dry-land areas having fine sediments and that little of it came directly from fresh till and glacial outwash. They find that most loess deposition in Nebraska correlates with interglacial time and that wind, correlated with other factors, is the major force in the genesis of loess.

The aggregate thickness of the loess mantle in this area, especially near the principal valleys, is relatively great, approaching 150 feet or more in places. Headward erosion into these areas of thick loess mantle rapidly develops the characteristic canyon topography of the region. As soon as the sod and soil cap of the upland plain is removed by undercutting, the relatively coarse silts of the underlying loess are subject to rapid erosion by water because of their silt texture and lack of cementation, and near-vertical canyon walls result. Such walls along water courses, roads, and in other places subject to erosion are common (Figs. 1 and 2). Moreover, weathering of the canyon wall tends to induce a vertical or near-vertical cleavage in the loessal materials forming lines of weakness along which the loess tends to slide downward. This results in the "catsteps" which are so typical of the side slopes of the uplands in this region (Figs. 3 and 4).

Catsteps are not only a prominent feature of the landscape, but they also greatly affect the distribution of the various types of vegetation. Hence, a knowledge of their origin is of considerable importance. According to Mr. E. C. Reed, catsteps are caused by the textural variations and the groundwater relationships within the loess and most commonly occur near the contacts between older and younger loesses, as at or near the Loveland-Peorian contact. The Loveland loess accumulated rapidly as a thick mantle over this region and its deposition was followed by a relatively long period of weathering and soil development. Thus a dark surface soil with a clayey subsoil was developed at the top of the Loveland. This differs greatly in texture and permeability not only from the coarse silt of the middle and lower parts of this loess but also from the lower and middle parts of the Peorian loess which was deposited upon it during a later period of loess accumulation. Under these conditions water from precipitation tends to move downward, often 30 to 40 feet, through the Peorian loess with comparative ease until the Peorian-Loveland contact is reached where permeability is greatly restricted and the groundwater movement is directed laterally toward

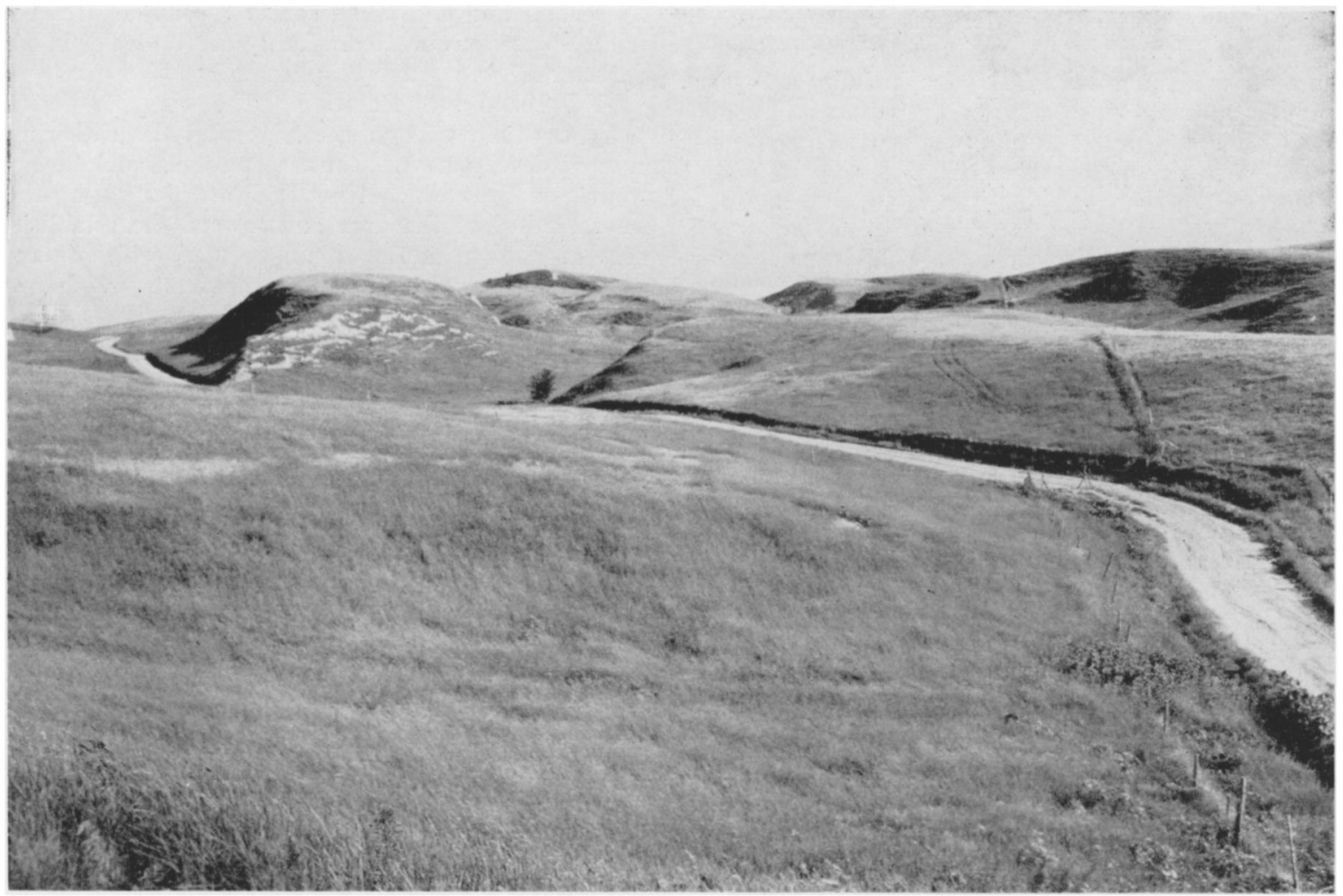

FIG. 1. View in the northwestern portion of the dissected loess plains showing the bluffs and rolling land characteristic of the area. The loess soil is protected by a thick carpet of blue grama (Bouteloua gracilis), a cover of western wheat grass (Agropyron smithii), or by other vegetation. 


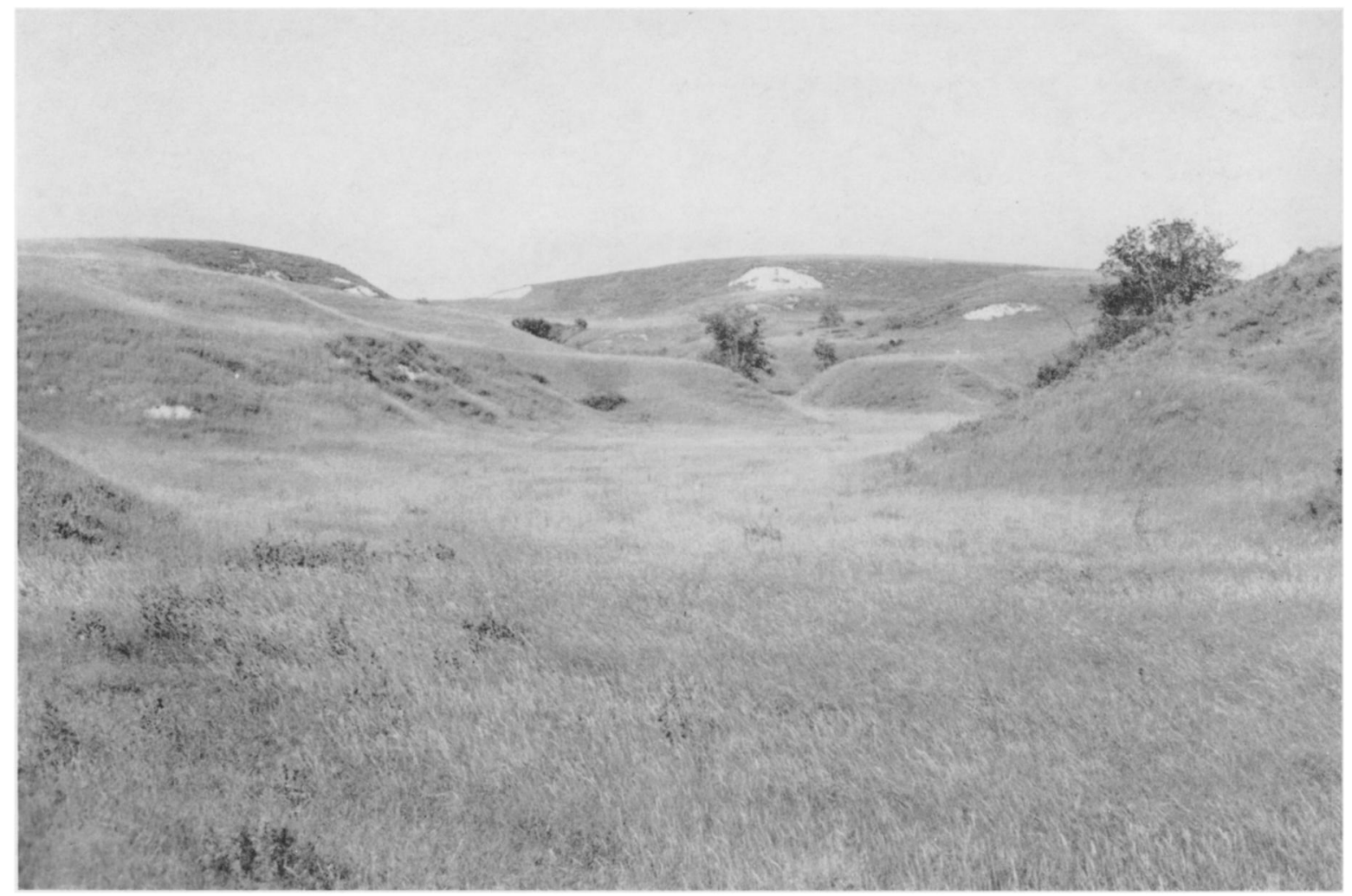

Fic. 2. A small flat-bottomed valley showing three nearly vertical canyon walls in the background as a result of natural erosion and slipping of the loess. Western wheat grass is on the canyon floor and scattered white elms (Ulmus americana) are on the slopes. Photo near Broken Bow, Nebr.

the valley or canyon sides where it is discharged as springs and causes the overlying Peorian loess to slip and slide valleyward. Catsteps are thus developed successively near the Loveland-Peorian contact and blocks of Peorian loess are moved down the valley sides below the Loveland-Peorian contact level.

\section{PHYSIOGRAPHY}

The general physiography is that of an upland plain, ranging from almost level to steeply rolling or hilly land. The average elevation of the plain is about 2,200 feet above sea level. It is traversed by numerous low-lying strips of flat alluvial land along the rivers and larger streams. Stream erosion and wind action have produced considerable relief. Over the greater part of the area the upland plain has been thoroughly dissected. It is now hilly. The hills are often 100 to 150 feet higher than the valleys between them (Fig. 5). The comparatively level areas are not extensive. They occupy the highest positions and occur principally near the center of the divides where the original constructional plain has escaped destructive erosion. Such areas are locally known as tablelands. The tableland areas are very gently undulating or aln:ost flat and are modified in places by small sinks or depressions. Nearly all of the area is well drained by rivers and streams flowing southeastward into the Platte River. Chief among these are North, Middle, and South Loup Rivers, and Wood River. Not only is the greater part of the region thoroughly drained but over large areas runoff is excessive and erosion is severe.

\section{CLIMATE}

This portion of the mixed prairie has a climate characterized by moderately long, cold winters and a fairly long growing season with hot summers. The growing season usually includes 140 to 155 days without severe frost and extends from early May until early October. During the summer the average day temperatures sometimes reach $90^{\circ} \mathrm{F}$. At such times the maximum daily temperature reaches or even exceeds $100^{\circ}$. Minimum temperatures of $15^{\circ}$ to $20^{\circ}$ or more below zero occur at intervals during the cold season when the vegetation is dormant. Mean annual temperature is about $48^{\circ} \mathrm{F}$.

The mean annual precipitation is 23.1 inches at Broken Bow in the northwest and 23.9 at Kearney on the southern edge of the loess hills. Its distribution is of the Great Plains type, nearly 80 percent occurring between April 1 and September 30. The greater part of the summer rainfall occurs during local thunderstorms. Often the rainfall is very heavy over a short period of time. In May and June periods of drought are uncommon, in July the distribution of rainfall is less favorable, and during August and September long periods of drought sometimes cause reduced yields even of the crop of native grasses. 


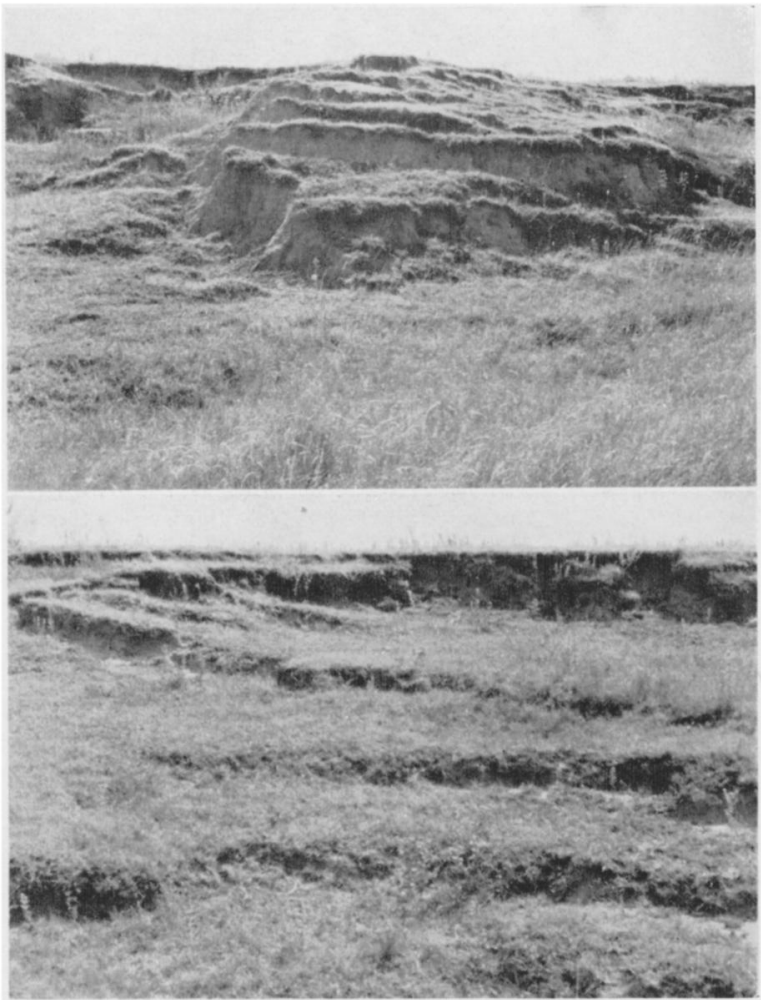

Fig. 3. (Upper) Typical catsteps on the side of a valley. These steps are 3 to 10 feet wide. Catsteps vary from 1 to 15 or more feet in width. On such areas both mid grasses, as side-oats grama (Bouteloua curtipendula) and little bluestem (Andropogom scoparius), and tall grasses, especially big bluestem ( $A$. furcatus), are common. Photo near Kearney. (Lower) View of catsteps in the McCan experimental pasture near Kearney, Nebr.

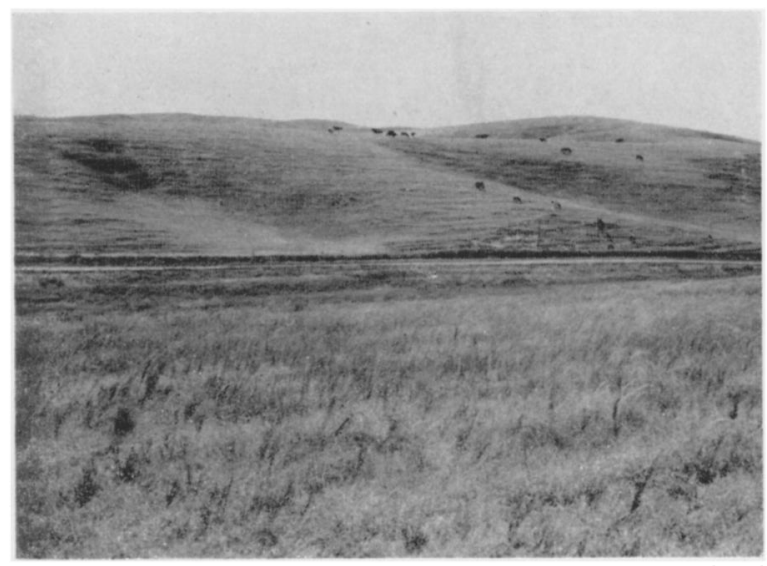

FIG. 4. Closely grazed range of blue grama north of Broken Bow showing hillside with much slumping of the soil to form eatsteps.

Snowfall is light, about 26 inches. Much of the snow is swept by winds into depressions, unless it lodges in a cover of grass, and thus often contributes but little to the supply of moisture of the soil upon which it falls. Wind movement is fairly constant and often high. It is an important factor in promoting water loss. Humidity is relatively low and

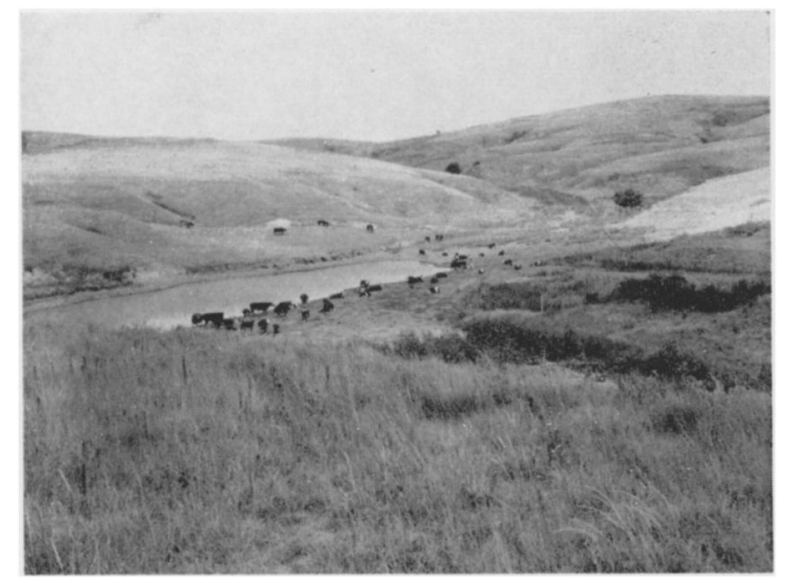

Fig. 5. Hilly range land between Broken Bow and Round Valley with the herd of cattle about the artificial pond in the ravine. This land is very easily eroded.

evaporation is high during summer and fall. The mixed prairie is typically a land of sunshine; the proportion of clear days is high. The elimate is well suited to the production of hay and grain crops and to the raising of livestock.

\section{SOIL}

Deposits of loess once covered the entire area in a smooth, thick mantle. These were later eroded and in places entirely removed by stream action. In its unweathered condition, the loess is uniform in texture and is composed largely of particles of silt. It varies in color from brownish yellow to yellow or almost white. Lime is abundant and a small quantity of iron stains the material in many places.

This area is in the part of the mixed prairie where the precipitation is moderate. The soils of the region have been leached of their carbonates and other easily soluble compounds to depths ranging up to about 3 feet. The most striking characteristic of most of the soils is the dark color of their surface layers. This results from the presence of organic matter or finely divided carbonaceous material, derived largely from the decayed roots of vegetation and intimately mixed with the mineral part of the soil. The color varies with the quantity of organic matter present. Soils are .usually darkest on the flatter areas and in the depressions where an abundance of moisture has especially favored the growth and decay of vegetation and where the position has prevented the removal of the organic matter through erosion. (cf. Hayes, et al. 1928).

Throughout the well drained, gently undulating or rolling areas where soils are kept in a relatively "young" state through gradual accretion of fresh materials (chiefly through wind action), conditions have favored the accumulation of organic matter. In this region soils are constantly rejuvenated by deposition of wind-blown dust and by the activities of burrowing animals (Thorp 1948). The soils have adjusted themselves to the climatic and vegetal environment and will retain approximately their pres- 
ent characteristies as long as the present natural conditions prevail.

\section{Holdrege Silt LoAM}

The well developed soils of uplands are predominately those of the Holdrege series. They have developed from loess. The profile shows three main layers or horizons-the surface soil or A horizon, the $B$ horizon or subsoil, and the parent material or the $\mathrm{C}$ horizon. The various horizons vary somewhat in thickness from place to place. A representative monolith sample from the southern part of the area is described.

A large trench was dug in a pasture where experiments were conducted in the loess bluffs area one mile north of Kearney (Fig. 6). This was in typical Holdrege silt loam. Both soil and rooting habits of plants were studied to a depth of 6 feet. The land was very gently sloping and the soil was mature. The first inch of dark grayish brown silt loam consisted of dust which had blown in from adjacent fields but was held firmly in place by the dense cover of buffalo grass. The $A_{1}$ horizon of friable dark grayish brown silt loam extended to a depth of 12 inches. It varied from fine crumb to medium granular structure and showed vertical

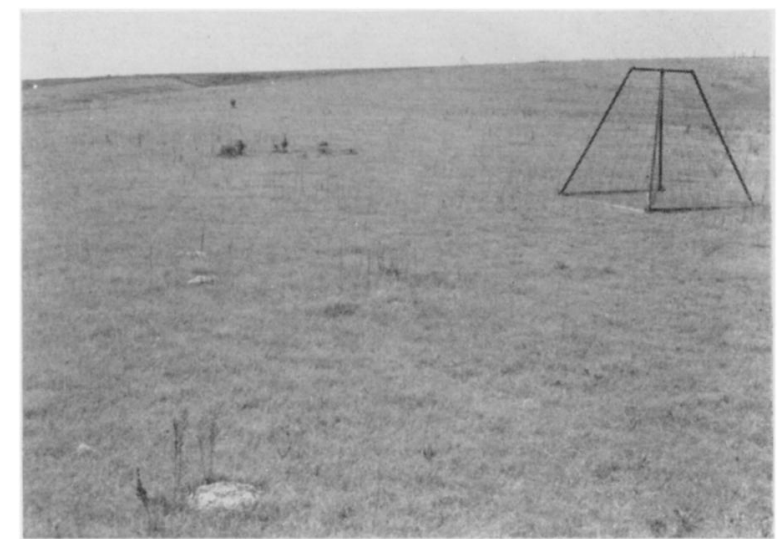

FIG. 6. Gently sloping land in a pasture near Kearney. The Holdrege silt loam is covered with a thick mat of buffalo grass (Buchloe dactyloides). The movable exclosure (30 square feet in area) is one of many used in ascertaining yield and consumption of forage.

cleavage. This is the horizon in which organic matter accumulates at or near the surface. The organic matter which gives this layer its dark color is thoroughly mixed with the mineral constituents and there is practically no color change (in the upper 6 inches) when the soil material is crushed (Table 1).

TABLE 1. Monolith sample of Holdrege silt loam from Kearney, Nebraska.

\begin{tabular}{|c|c|c|c|c|c|c|c|}
\hline \multirow{2}{*}{ Horizon } & \multirow{2}{*}{$\begin{array}{l}\text { Inches } \\
\text { from } \\
\text { surface }\end{array}$} & \multicolumn{2}{|c|}{ Color $^{1}$} & \multirow{2}{*}{ Texture } & \multirow{2}{*}{ Structure } & \multirow{2}{*}{$\begin{array}{l}\text { Consistence } \\
\text { (moist) }\end{array}$} & \multirow{2}{*}{$\begin{array}{l}\mathrm{pH} \text { by } \\
\text { Soiltex }\end{array}$} \\
\hline & & Dry & Moist & & & & \\
\hline $\begin{array}{l}\text { Recent dust. . } \\
\text { accumulation }\end{array}$ & $0-1$ & $\begin{array}{l}\text { Grayish brown } \\
10 \text { YR } 5 / 2\end{array}$ & $\begin{array}{l}\text { Dark grayish brown } \\
10 \mathrm{YR} 3 / 2\end{array}$ & $\begin{array}{l}\text { Silt } \\
\text { loam }\end{array}$ & $\begin{array}{l}\text { Fine crumb } \\
\text { (soft fine grains) }\end{array}$ & Friable & 6.5 \\
\hline$A_{1-1} \ldots$ & $1-6$ & $\begin{array}{l}\text { Grayish brown } \\
\text { 10YR 4/1.5 }\end{array}$ & $\begin{array}{l}\text { Dark grayish brown } \\
\text { 10YR } 3 / 1.5\end{array}$ & $\begin{array}{l}\text { Silt } \\
\text { loam }\end{array}$ & $\begin{array}{l}\text { Fine crumb; } \\
\text { vertical cleavage }\end{array}$ & Friable & 6.5 \\
\hline$A_{1-2}$. & $6-12$ & $\begin{array}{l}\text { Grayish brown } \\
10 \mathrm{YR} 4 / 2\end{array}$ & $\begin{array}{l}\text { Dark grayish brown } \\
\text { 10YR } 3 / 2\end{array}$ & $\begin{array}{l}\text { Silt } \\
\text { loam }\end{array}$ & $\begin{array}{l}\text { Strong, fine to } \\
\text { medium granular; } \\
\text { vertical cleavage }\end{array}$ & Friable & 6.8 \\
\hline$B_{1}$, & $12-15$ & $\begin{array}{l}\text { Grayish brown } \\
\text { 10YR } 4 / 2\end{array}$ & $\begin{array}{l}\text { Dark grayish brown } \\
\text { 10YR } 3 / 2\end{array}$ & $\begin{array}{l}\text { Light }^{2} \\
\text { silty } \\
\text { clay loam }\end{array}$ & $\begin{array}{l}\text { Prismatic-nuciform- } \\
\text { granular (compound) } \\
\text { with strong vertical } \\
\text { cleavage }\end{array}$ & $\begin{array}{l}\text { Slightly } \\
\text { plastic }\end{array}$ & 6.8 \\
\hline $\mathrm{B}_{2-1} \ldots$ & $15-22$ & $\begin{array}{l}\text { Grayish brown } \\
10 \mathrm{YR} 5 / 2\end{array}$ & $\begin{array}{l}\text { Grayish brown } \\
\text { 10YR 4/2 }\end{array}$ & $\begin{array}{l}\text { Silty } \\
\text { clay loam }\end{array}$ & $\begin{array}{l}\text { Do. primary aggre- } \\
\text { gates } 1 / 2 \text { to } 3 / 4 \\
\text { inch in diameter }\end{array}$ & $\begin{array}{l}\text { Moderately } \\
\text { plastic }\end{array}$ & 7.0 \\
\hline B.... & $22-28$ & $\begin{array}{l}\text { Light brownish } \\
\text { gray } \\
\text { 10YR } 6 / 1.5\end{array}$ & $\begin{array}{l}\text { Grayish brown } \\
\text { 10YR 5/1.5 }\end{array}$ & $\begin{array}{l}\text { Silty } \\
\text { clay } \\
\text { loam }\end{array}$ & $\begin{array}{l}\text { Imperfect prismat- } \\
\text { ic-nuciform }\end{array}$ & $\begin{array}{l}\text { Moderately } \\
\text { plastic }\end{array}$ & 7.0 \\
\hline $\mathrm{B}_{3} \ldots$ & $28-36$ & $\begin{array}{l}\text { Light yellowish } \\
\text { brown } \\
2.5 \mathrm{Y} 6 / 3\end{array}$ & $\begin{array}{l}\text { Yellowish brown } \\
2.5 Y 5 / 3\end{array}$ & $\begin{array}{l}\text { Heavy }{ }^{2} \\
\text { silt } \\
\text { loam }\end{array}$ & $\begin{array}{l}\text { Imperfect prismat- } \\
\text { ic; weakly } \\
\text { nuciform second- } \\
\text { ary aggregates }\end{array}$ & $\begin{array}{l}\text { Slightly } \\
\text { plastic }\end{array}$ & 7.5 \\
\hline $\mathrm{Bca}^{3}$ or $\mathrm{C}_{1}$ & $36-48$ & $\begin{array}{l}\text { Mottled pale } \\
\text { yellow and white } \\
2.5 \mathrm{Y} 7 / 4,8 / 1\end{array}$ & $\begin{array}{l}\text { Light yellowish } \\
\text { brown } \\
2.5 \mathrm{Y} 6 / 3\end{array}$ & $\begin{array}{l}\text { Silt } \\
\text { loam }\end{array}$ & $\begin{array}{l}\text { Prismatic to } \\
\text { massive }\end{array}$ & Friable & $\begin{array}{l}\quad 8.0 ; \\
\text { soft lime } \\
\text { carbonate; } \\
\text { lime con- } \\
\text { critions }\end{array}$ \\
\hline
\end{tabular}

1 Provisional Soil Survey color names, based on standard Munsell color charts; e.g. 10YR 5/2 means: hue 10 yellow-red; value on lightness scale is 5 ; chroma saturation is 2 . The color names are those in common usage.

2 "Light" silty clay loam means that the soil has near the minimum of clay content for that texture class; "heavy" silt loam has a maximum of clay allowable for silt loam.

3 The main $\mathrm{C}$ horizon or "parent material" was not reached in this sample. 
The $B_{1}$ horizon, which is transitional from the lighter textured surface soil to the heavier textured subsoil, occurred between 12 and 15 inches in depth. This light silty clay loam was slightly plastic and showed strong vertical cleavage. The $\mathrm{B}_{2}$ horizon of grayish brown silty clay loam showed moderate plasticity. It occurred at a depth of 15 to 28 inches. This is the horizon of maximum clay development or accumulation. Here the coating of organic matter around the soil granules becomes thinner. When the soil is eut with a sharp instrument or the materials are crushed, the lighter interior of the granules is exposed and the soil becomes lighter in color.

The $\mathrm{B}_{3}$ horizon (28 to 36 inches depth) occurred just above the horizon of lime accumulation. It is a yellowish brown, heavy silt loam. The layer of lime accumulation, characteristic of Chernozems, began at 36 inches depth and extended to about 6 feet. This was the approximate depth of the solum, below which the $\mathrm{C}$ horizon of parent material was encountered. This was yellowish-brown, friable, silty, structureless material which contained much lime. The $\mathrm{pH}$ increased gradually from 6.5 in the first foot to 7.0 in the seconcl, but was 7.5 to 8 at greater depths.

We are indebtcd to Mr. James Thorp, Principal Soil Correlator, Great Plains States, U. S. Division of Soil Survey, for a complete description of monoliths of soils (Tables 1 and 2) which were brought to the laboratory for study.

\section{Colby Silt Loam}

Over much of the area, the Colby soils occupy the greater portions of the uplands. "The light-colored Colby soils may be regarded as immature. Constant erosion has prevented the accumulation of much organic matter and as the surface water flows rapidly from the slopes, leaching of the carbonates from the subsoil does not proceed faster than the new material is exposed as a result of erosion. The surface layer is thin and lighter in color than that of the Holdrege . . . soils.

"Colby silt loam is grayish brown, light grayish brown, or ash-gray friable silt loam from 4 to 8 inches deep. The upper part of the subsoil is of similar or slightly lighter color, but is identical in texture and structure. . . . On the more gradual slopes and more rounded divides, conditions have favored growth and decay of vegetation. Here the surface soil is deeper and darker than typical. On steeply sloping areas, erosion has prevented the accumulation of organic matter and the soil is consequently light in color. In many places the surface layers have been entirely removed by erosion, exposing the light, yellowish-gray parent loess [Fig. 7]. ... Areas of this land vary from rolling to extremely rough and dissected. Even areas of moderate relief are dissected by numerous intermittent streams which have cut deep and, in places, almost perpendicular-walled valleys. Soil slipping is common in rougher areas, and the slopes in many places present short vertical exposures having a step-like

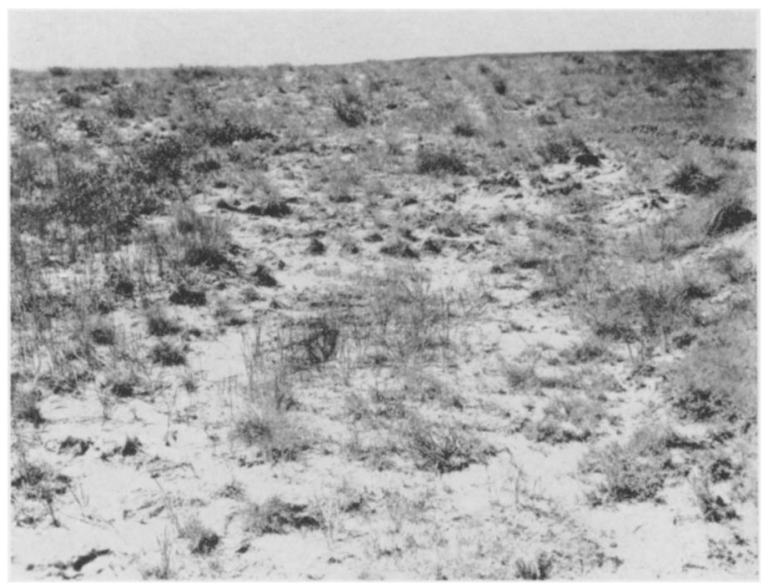

FIG. 7. Colby soil exposed on an eroding slope. The (-hief grasses are purple three-awn (Aristida purpurea) and western wheat grass.

appearance. Drainage is everywhere thorough and in most places excessive." (Hayes et al. 1928.)

Colby soils have neither a horizon of compaction nor one of lime accumulation, but the grayish-brown surface soil rests directly upon the light-colored parent loess.

The surface soil of Colby silt loam extends to an average depth of 6 inches. In the following profile the depth is 4 inches, exclusive of the $A_{1-3}$ transitional horizon in which the soil properties are mom like those of the A than the B horizon (Table 2).

The soil profile of Colby silt loam was examintd on a moderately sloping hillside in a large pasture 5 miles southeast of Broken Bow (Fig. 8). It supported a good cover of blue grama (Bouteloua gracilis). 2 The surface 0.75 inch is a friable, dark grayish brown soil with a medium to fine crumb structure. This $A_{1-1}$ horizon, which seldom exceeds a few inches in thickness, has accumulated more organic matter and is consequently darker in color than any other horizon. The second horizon $\left(A_{1-2}\right)$ is usually about 4 inches thick. In texture it is similar to the soil above but the color is lighter and the soil is weakly granular. The $\mathrm{A}_{1-3}$ transitional horizon is a dark gravish-brown, heavy silt loam of granular structure with prismatic cleavage.

The subsoil $\left(B_{1}\right.$ horizon) composes much of the second foot in depth. It is a light silty clay loam, grayish brown in color with considerable plasticity and a nut-like granular structure. Characteristics of the parent material are given in Table 2 . The $\mathrm{pH}$ value to a depth of 20 inches was 7.0 but increased to 7.5 or $8.0+$ in the parent material which was rich in lime.

\section{Analyses of Solls}

Mechanical analyses were made of the Holdrege silt loam soil in the McCan pasture near Kearney

1 Nomenclature of grasses follows Hitchcock's "Manual of the Grasses of the U. S." that of other species is according to Britton and Brown's "Illustrated Flora," unless other authority is given. 
TABLE 2. Monolith sample of Colby silt loam1 from Broken Bow, Nebraska.

\begin{tabular}{|c|c|c|c|c|c|c|c|}
\hline \multirow{2}{*}{ Horizon } & \multirow{2}{*}{$\begin{array}{l}\text { Inches } \\
\text { from } \\
\text { surface }\end{array}$} & \multicolumn{2}{|c|}{ Color ${ }^{2}$} & \multirow{2}{*}{ Texture } & \multirow{2}{*}{ Structure } & \multirow{2}{*}{ Consistence } & \multirow{2}{*}{$\begin{array}{l}\text { pH by } \\
\text { Soiltex }\end{array}$} \\
\hline & & Dry & Moist & & & & \\
\hline$A_{1-1}$. & $0-3 / 4$ & $\begin{array}{l}\text { Grayish brown } \\
\text { 10YR } 4 / 2\end{array}$ & $\begin{array}{l}\text { Dark grayish brown } \\
\text { 10YR } 3 / 2\end{array}$ & Silt loam & $\begin{array}{l}\text { Medium to fine } \\
\text { crumb }\end{array}$ & Friable & 7.0 \\
\hline$A_{1-2} \ldots \ldots \ldots$ & $3 / 4-4$ & $\begin{array}{l}\text { Grayish brown } \\
\text { 10YR } 5 / 2\end{array}$ & $\begin{array}{l}\text { Grayish brown } \\
\text { 10YR } 4 / 2\end{array}$ & Silt loam & $\begin{array}{l}\text { Granular or } \\
\text { crumb }\end{array}$ & Friable & 7.0 \\
\hline $\mathbf{A}_{1-3} \ldots \ldots$ & $4-12$ & $\begin{array}{l}\text { Grayish brown } \\
\text { 10YR } 4.5 / 2\end{array}$ & $\begin{array}{l}\text { Dark grayish brown } \\
\text { 10YR } 3.5 / 2\end{array}$ & $\begin{array}{l}\text { Heavy } \\
\text { silt } \\
\text { loam }\end{array}$ & $\begin{array}{l}\text { Granular with } \\
\text { prismatic cleavage }\end{array}$ & $\begin{array}{l}\text { Friable, } \\
\text { moist; } \\
\text { slightly } \\
\text { plastic wet }\end{array}$ & 7.0 \\
\hline$B_{1} \ldots \ldots \ldots$ & $12-20$ & $\begin{array}{l}\text { Grayish brown } \\
\text { 10YR 5/2 }\end{array}$ & $\begin{array}{l}\text { Grayish brown } \\
\text { 10YR 4/2 }\end{array}$ & $\begin{array}{l}\text { Light } \\
\text { silty } \\
\text { clay } \\
\text { loam }\end{array}$ & $\begin{array}{l}\text { Medium prismatic- } \\
\text { nuciform- } \\
\text { granular }^{3}\end{array}$ & $\begin{array}{l}\text { Slightly } \\
\text { plastic, } \\
\text { moist, to } \\
\text { plastic, wet }\end{array}$ & 7.0 \\
\hline $\mathrm{C}_{1} \ldots \ldots \ldots$ & $20-32$ & $\begin{array}{l}\text { Olive brown } \\
2.5 \mathrm{Y} 5.5 / 3\end{array}$ & $\begin{array}{l}\text { Dark olive brown } \\
2.5 \mathrm{Y} 4.5 / 3\end{array}$ & $\begin{array}{l}\text { Silt } \\
\text { loam }\end{array}$ & $\begin{array}{l}\text { Prismatic-coarse } \\
\text { nuciform }\end{array}$ & Friable & 7.5 \\
\hline $\mathrm{C}_{2} \ldots$ & $32-46$ & $\begin{array}{l}\text { Light olive } \\
\text { brown, mottled } \\
\text { yellowish brown } \\
2.5 \mathrm{Y} 6 / 3,10 \mathrm{YR} \\
5 / 4\end{array}$ & $\begin{array}{l}\text { Grayish brown, } \\
\text { mottled yellowish } \\
\text { brown } \\
2.5 \mathrm{Y} 4.5 / 2,10 \mathrm{YR} \\
4 / 4\end{array}$ & $\begin{array}{l}\text { Silt } \\
\text { loam }\end{array}$ & Coarse prismatic & Friable & $\begin{array}{l}\quad 8.0 \\
\text { (Calcare- } \\
\text { ous) }\end{array}$ \\
\hline $\mathrm{C}_{3} \ldots$ & $46-48+$ & $\begin{array}{l}\text { Light brownish } \\
\text { gray, mottled } \\
\text { white } 2.5 \mathrm{Y} \\
6 / 2,9 / 2\end{array}$ & $\begin{array}{l}\text { Grayish brown, } \\
\text { mottled white } \\
2.5 \mathrm{Y} 4.5 / 2,8 / 2\end{array}$ & $\begin{array}{l}\text { Silt } \\
\text { loam }\end{array}$ & $\begin{array}{l}\text { Coarse prismatic } \\
\text { grading to } \\
\text { massive }\end{array}$ & $\begin{array}{l}\text { Very } \\
\text { friable }\end{array}$ & $\begin{array}{l}8.0+ \\
\text { (Calcare- } \\
\text { ous) }\end{array}$ \\
\hline
\end{tabular}

1 This soil has been called Colby silt loam over a wide area in Nebraska. but it is darker colored than the Colby silt loam of eastern Colorado and western Kansas. It also contains more rlay in the B horizon than is typical of Colby silt loam. It resembles closely the Ulysses silt loam, a series recognized tentatively in western Kansas.

2. Provisional Soil Survey color names, based on Munsell color charts.
3 Most soil structure is complex, including large aggregates that fall apart into smaller ones of different shapes.

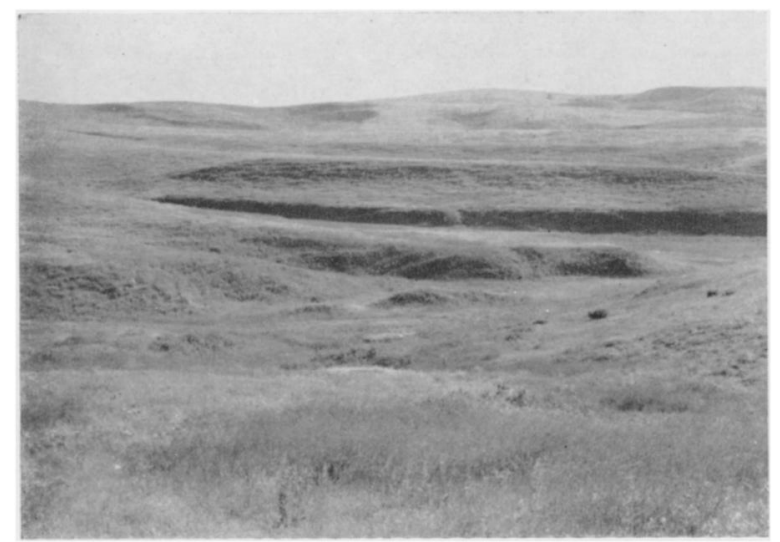

F'rG. 8. Typical range land near Broken Bow. The soil is Colby silt loam and the chief grass is blue grama. Note the catsteps which cause a rough surface (darker) on the hillsides.

and of a small area of Holdredge silt loam from a second pasture 5 miles west of Kearney (Sheen pasture), where studies on yield and consumption of forage were made. The hydrometer method as described by Bouyoucos (1936) was used, but with slight modifications (Table 3 ).

The two soils are somewhat similar. Both are very fine textured. The second is less deeply developed, but it has the more pronounced accumulation of elay.
TABLE 3. Mechanical analyses of soils. The percentage of the clay fraction less than $0.002 \mathrm{~mm}$. is also in. cluded in the material less than 0.005 .

\begin{tabular}{|c|c|c|c|c|}
\hline \multirow{3}{*}{$\begin{array}{l}\text { Depth, } \\
\text { inches }\end{array}$} & \multicolumn{4}{|c|}{ Percentage of oven-dry soll } \\
\hline & \multirow{2}{*}{$\begin{array}{c}\text { Sand } \\
>0.05 \mathrm{~mm} .\end{array}$} & \multirow{2}{*}{$\begin{array}{c}\text { Silt } \\
.05 \text { to } \\
.005 \mathrm{~mm} .\end{array}$} & \multicolumn{2}{|c|}{ Clay } \\
\hline & & & $<0.005 \mathrm{~mm}$. & $<0.002 \mathrm{~mm}$. \\
\hline
\end{tabular}

\begin{tabular}{r|r|r|r|r}
\multicolumn{5}{c}{ (1) From McCan Pasture } \\
$0-6 \ldots \ldots$ & 14.4 & 59.4 & 26.2 & 23.6 \\
$6-12 \ldots$ & 16.4 & 53.2 & 30.4 & 25.8 \\
$12-24 \ldots$ & 15.4 & 52.4 & 32.2 & 33.7 \\
$24-36 \ldots$ & 9.0 & 52.7 & 38.3 & 35.8 \\
$36-42 \ldots$ & 15.0 & 52.1 & 32.9 & 29.4
\end{tabular}

(2) From Sheen Pasture

\begin{tabular}{r|r|r|r|r}
$0-6 \ldots \ldots$ & 19.3 & 54.0 & 26.7 & 24.1 \\
$6-12 \ldots$ & 15.7 & 51.7 & 32.6 & 30.4 \\
$12-24 \ldots$ & 11.9 & 48.2 & 39.9 & 37.8 \\
$24-36 \ldots$ & 8.7 & 51.3 & 40.0 & 37.8 \\
$36-42 \ldots$ & 15.9 & 58.9 & 25.2 & 22.1 \\
\hline
\end{tabular}

The percentage of aggregation of these soils as determined by the hydrometric method, and the percentage of organic matter and nitrogen as determined by the modified Walkley-Black method are shown in Table 4.

An examination of the data in Table 4 reveals that the first soil has only moderate aggregation and 
TABLE 4. Percentage of aggregates greater than $0.25 \mathrm{~mm}$. (based on oven-dry weight), organic matter, and total nitrogen in soils in Table 3 . U, upland; S, moderate slope.

\begin{tabular}{|c|c|c|c|c|c|c|c|}
\hline \multirow{2}{*}{ Depth } & \multirow{2}{*}{$\begin{array}{c}(1) \\
\text { McCan } \\
\text { pasture }\end{array}$} & \multirow{2}{*}{$\begin{array}{c}\text { (2) } \\
\text { Sheen } \\
\text { pasture }\end{array}$} & \multirow{2}{*}{ Depth } & \multicolumn{2}{|c|}{$\begin{array}{l}\text { McCAN } \\
\text { PASTURE }\end{array}$} & \multicolumn{2}{|c|}{$\begin{array}{c}\text { ShEen } \\
\text { PASTURE }\end{array}$} \\
\hline & & & & $\begin{array}{l}\text { Organic } \\
\text { Matter }\end{array}$ & Total $\mathrm{N}$ & $\begin{array}{l}\text { Organic } \\
\text { Matter }\end{array}$ & Total N. \\
\hline $0-2$ & $\begin{array}{c}\text { percent } \\
21.3\end{array}$ & $\begin{array}{c}\text { percent } \\
14.0\end{array}$ & $\mathrm{U}^{0-4}$ & 5.17 & .170 & 4.38 & .159 \\
\hline $\begin{array}{l}2-6 \ldots \\
6-12 . .\end{array}$ & $\begin{array}{l}22.1 \\
20.2\end{array}$ & $\begin{array}{l}13.9 \\
18.0\end{array}$ & $4-12$ & 4.13 & .137 & 4.07 & .141 \\
\hline $12-24$ & 24.5 & 17.3 & $s^{0-4}$ & 4.46 & .161 & 5.11 & .194 \\
\hline $\begin{array}{l}24-36 \ldots \ldots \\
36-40 \ldots \ldots\end{array}$ & $\begin{array}{l}17.7 \\
14.2\end{array}$ & $\begin{array}{l}13.1 \\
11.1\end{array}$ & 4-12 & 4.09 & .143 & 3.29 & .110 \\
\hline
\end{tabular}

is not very stable. Aggregation in the second soil is low and this soil is even less stable. For example, at Lincoln, Nebraska, on the Experimental Farm the topsoil (upper 6 inches) under native grasses has a degree of aggregation of 80 percent (Bertramson and Rhoades 1938). In the first soil, the 24.5 percent aggregation corresponds to the silty clay loam texture shown in Table 1 . In the second, the greater aggregation at 6 to 24 inches corresponds to the presence of the layer of heavy silt loam and light silty clay loam at this depth. Although at these depths the clay and organic matter produce maximum aggregation, at 24-36 inches the increased clay content is not accompanied by increased aggregation. The decrease in influence of organic matter is likewise seen in comparing the 0-6 inch depth with the 6-12 inch. A large decrease in organic matter is not accompanied by much change in aggregation.

Both soils are low in organic matter and in total nitrogen. Since the coefficient of correlation between the Walkley-Black method and the modified Robinson method is very high (Smith and Weldon 1940), the results may be compared with others determined by the latter method. Shively and Weaver (1939) report a percentage of organic matter of 4.18 to 4.56 in native prairie at Holdrege, Oxford, and at another station in the Holdrege soil series under an average precipitation of about 23 inches. The percentage of nitrogen ranged from 0.178 to 0.206 . Similar data from Lincoln and other stations in eastern Nebraska in the same soil series (precipitation about 29 inches) gave a percentage of organic matter of 6.07 to 6.25 , and 0.260 to 0.278 percent of nitrogen. All the preceding samples were from a depth of $0-4$ inches.

\section{Erosion}

The erosiveness of these fine textured soils is very high and the need of a continuous protective cover of grass is correspondingly great. There is some constant erosion by wind and water from these steep bluffs, but when the cover is broken by grazing or trampling, erosion almost immediately becomes serious. Except in years of drought, the ranges-at least the larger ones-are permitted to retain a rea- sonable amount of uneaten forage and a thin layer of debris on the soil. But this does not maintain under close grazing, and in the best ranges trampling results in the formation of paths which often develop into deep gullies. These are usually the long trails from the distant portions of the range. They are used regularly by the livestock traveling to and from the wells or ponds where they obtain water (Fig. 9). However, paths are made in grazing steep banks and in passing from one valley to another.

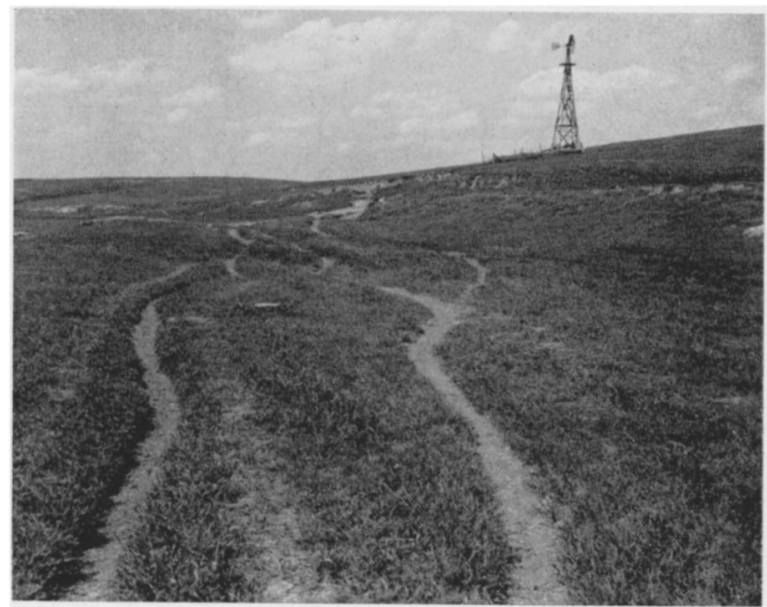

FIG. 9. A few of the many paths leading to the windmill. Note on the left the beginning of new paths on both sides of the older one which is several inches deep.

At first the soil is compacted in the paths, then the grass dies. Next the foot-wide paths begin to erode. The soil, loosened by trampling, blows a way or is washed away and the paths are decponed by rains. As the depth increases to several inches the path is abandoned and a new, more or less parallel one is made. But erosion continues and a ditch three

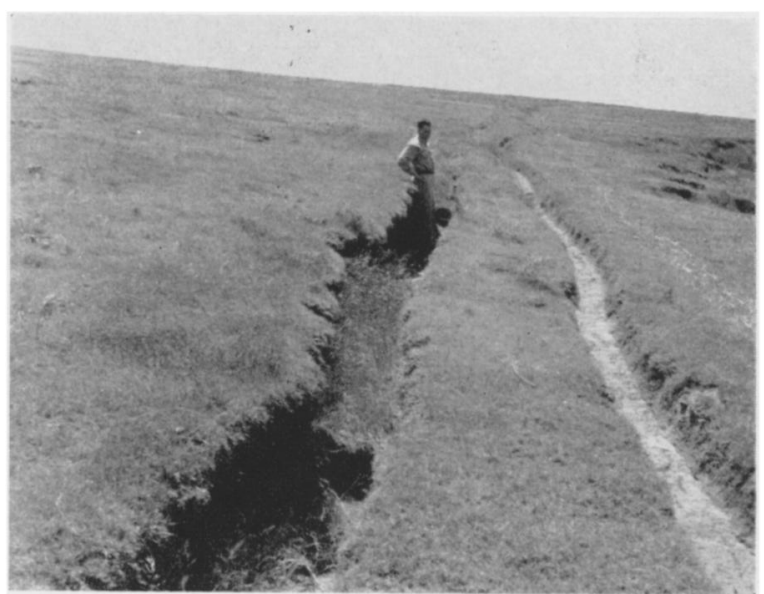

FIG. 10. Deeply eroded parallel paths in loess. Dark places in path on left are 40 inches deep. The general cover is buffalo grass but hairy chess (Bromus commutatus) grows thickly in portions of the old path. The second path is 11 inches deep and is being abandonerl for a new one on the right, in which some grass still grows. 
or more feet deep may be formed (Fig. 10). The banks eave, the debris is washed away, and from the old path or series of paths deep eroded areas a rod to several rods in width may result.

The cutting back of a ravine to near the top of the bluff and its joining a similar ravine on the opposite side and thus dissecting the hill or range of hills is not uncommon (Figs. 11 and 12). It is frequently aided by the trampling of livestock. In one of the experimental pastures where the well was near the far end of the second 80 acres of the quarter section, the cattle continuously trailed up one ravine, over a steep ridge, and down another. These paths were, in a few years, eroded so deeply that it became difficult to drive from the gate in the near end of the pasture to the more distant part. Only a few rods separated two other favorite grazing grounds on lowlands on two sides of a long steep ridge. Although deep paths had not yet been formed, there was much trampling and thinning of the cover where the herd was observed several times passing over the ridge between these two grazing grounds.

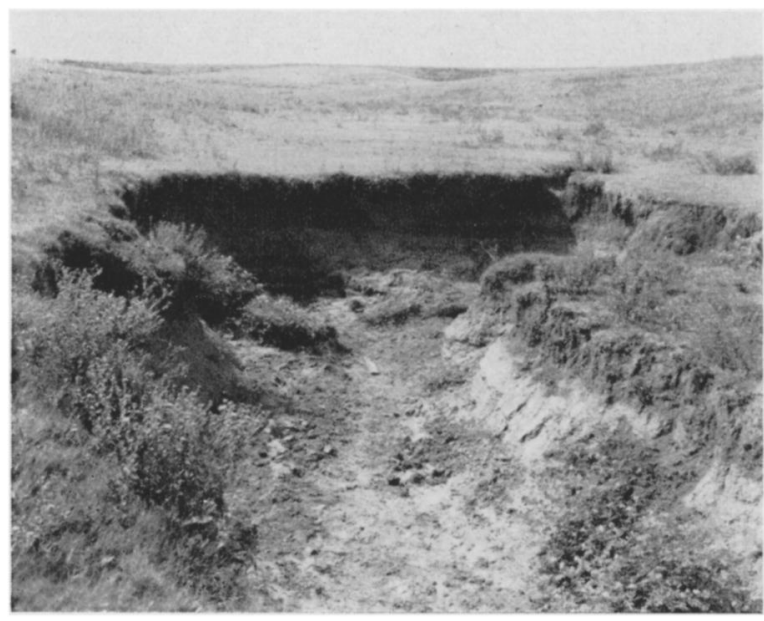

Fig. 11. Undercutting of Holdredge silt loam in the MeCan pasture near Kearney. The valley floor is clothed with a dense cover of buffalo grass, but floodwaters pour over the bank and undermine the soil which is then pulled down by gravity. Note the catstep on the right and the loose soil which has fallen from the bank.

\section{ROOT RELATIONS}

Previous studies had led the writers to believe that in these mellow soils of normally moderately low water content, roots of the native plants would penetrate deeply (Weaver 1919). Several years of good precipitation following the great drought of 1933 to 1940 has resulted in complete replenishment of subsoil moisture. The examination of root systems in several sites confirmed this belief.

Buffalo grass (Buchloe dactyloides) was studied near Kearney in Holdrege silt loam. The roots were traced in the walls of a trench excavated on nearly level land, some to a depth of 6 feet where they ended after extending well into the lime layer. The soil was moist to only about 5 feet. In one end

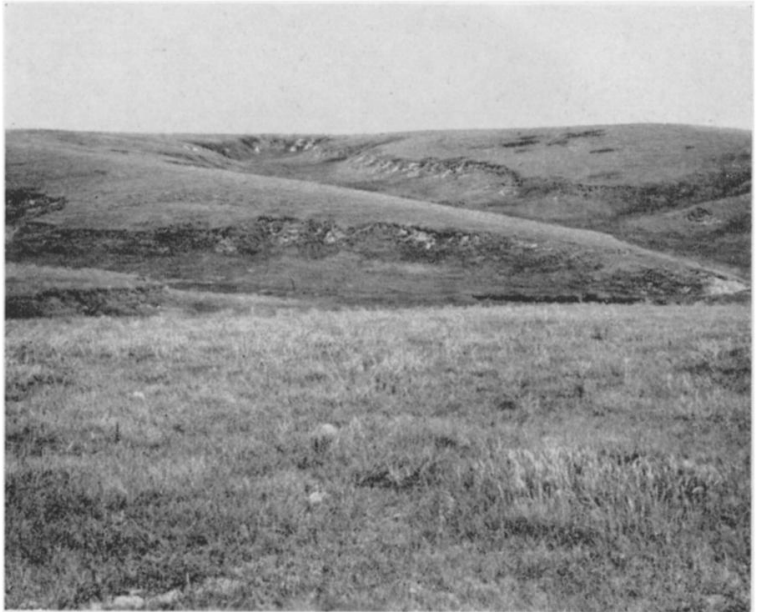

Frg. 12. Typical gulley which has eroded far toward the top of the hill. Light colored soil is exposed at various places along the steep banks. This is typical loessbluff topography.

of the trench where the water had penetrated to only 4.5 feet, no roots were found beyond this depth.

A monolith of the soil 12 inches wide, 4 feet long, and 3 inches into the vertical wall of the trench was obtained without injury to the soil structure or grass roots. By means of long soaking and careful washing, the soil was finally removed from the roots. They were then arranged under water in their natural position, transferred to a black background, and photographed (Fig. 13). The great bulk of the roots grew so nearly vertically downward that practically all that extended into the second foot reached the bottom of the 3-inch-thick monolith. Although these fine, tough roots were branched throughout their length, the greatest number and the best branching occurred in the $\mathrm{A}$ soil horizon and its transition to the $B$ horizon, that is, to a depth of 15 inches. The leafy shoots were lightly grazed to a height of 2.5 inches.

Studies of root depth and distribution were made in Colby silt loam half way down a steep hillside (slope 15 percent). At a depth of 19 inches a darker layer proved to be the top of a buried soil. The wind-carried Peorian loess had been deposited over a mature soil formed from the upper portion of previously deposited Loveland loess. This dark layer was 10 inches deep. The second layer of old "topsoil" seemed to stimulate greater root branching. The mass of buffalo grass roots was very dense to 52 inches. Roots in this very moist soil were numerous to 5 feet, and some reached 6 feet 3 inches in depth.

Further excavations were made in Colby silt loam in other prairies about 5 and 7 miles, respectively, northwest of Kearney. The roots of a dense stand of western wheat grass (Agropyron smithii) were examined on a hillside. They nearly all penetrated vertically downward, some extending into the moist subsoil to 10 feet and 3 inches, where the clear, white root tips were found. They were identical with these 


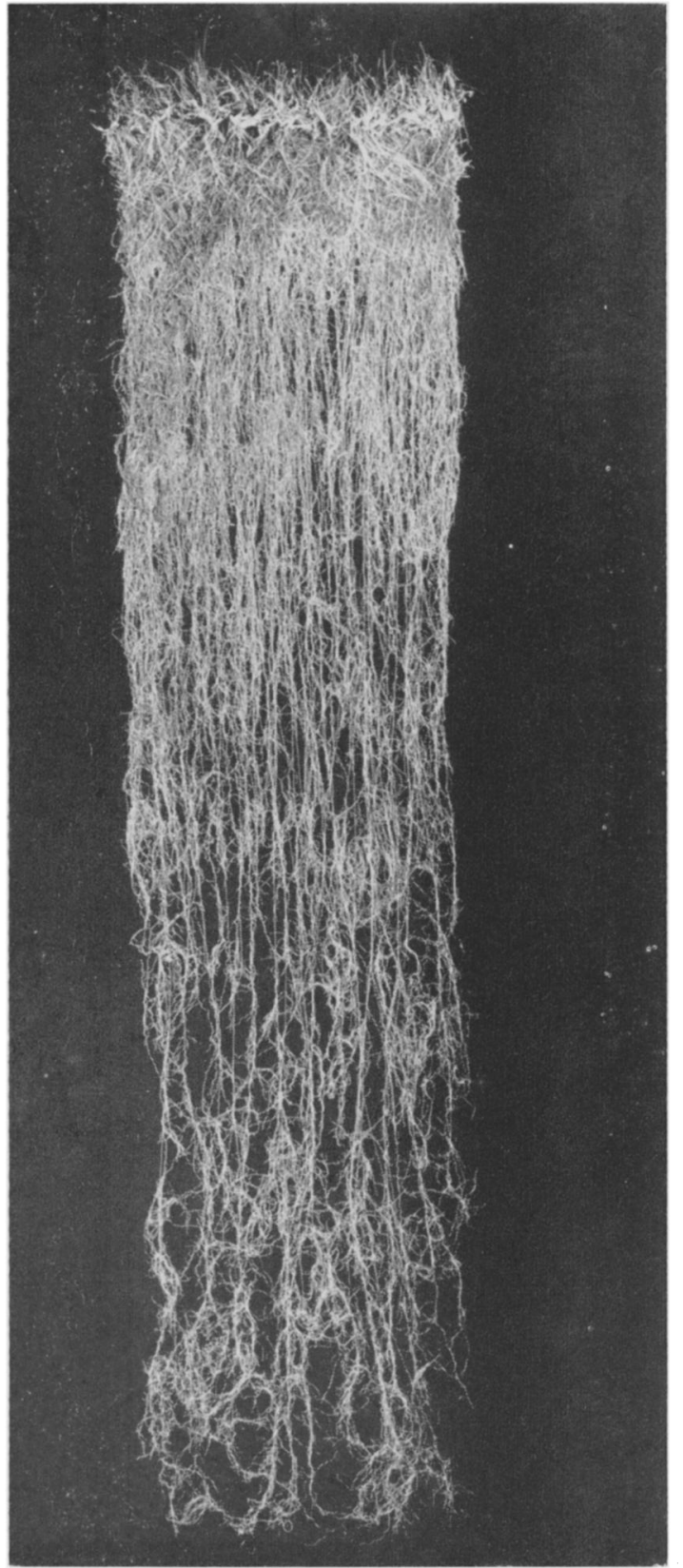

FIG. 13. Roots of buffalo grass to a depth of 4 feet. Note their greater number and more profuse branching in the surface 15 inches of soil. Note also the branching habit in the deeper soil.

excavated in Wabash silt loam at Lincoln (Fig. 14). Roots of big bluestem in this Colby soil were abundant at 7.5 feet depth and a few were traced to 8 feet. But these root depths were exceeded, as usual, by those of certain perennial forbs.

The tap root of an old plant of few-flowered psoralea (Psoralea tenuiflora) was 1.5 inches in diameter near the soil surface and, after some branching, $5 \% 8$ inch thick at 9 feet in depth. At greater depths it gave off several branches, some of which were traced 6 feet deeper but not to their ends. Tap roots

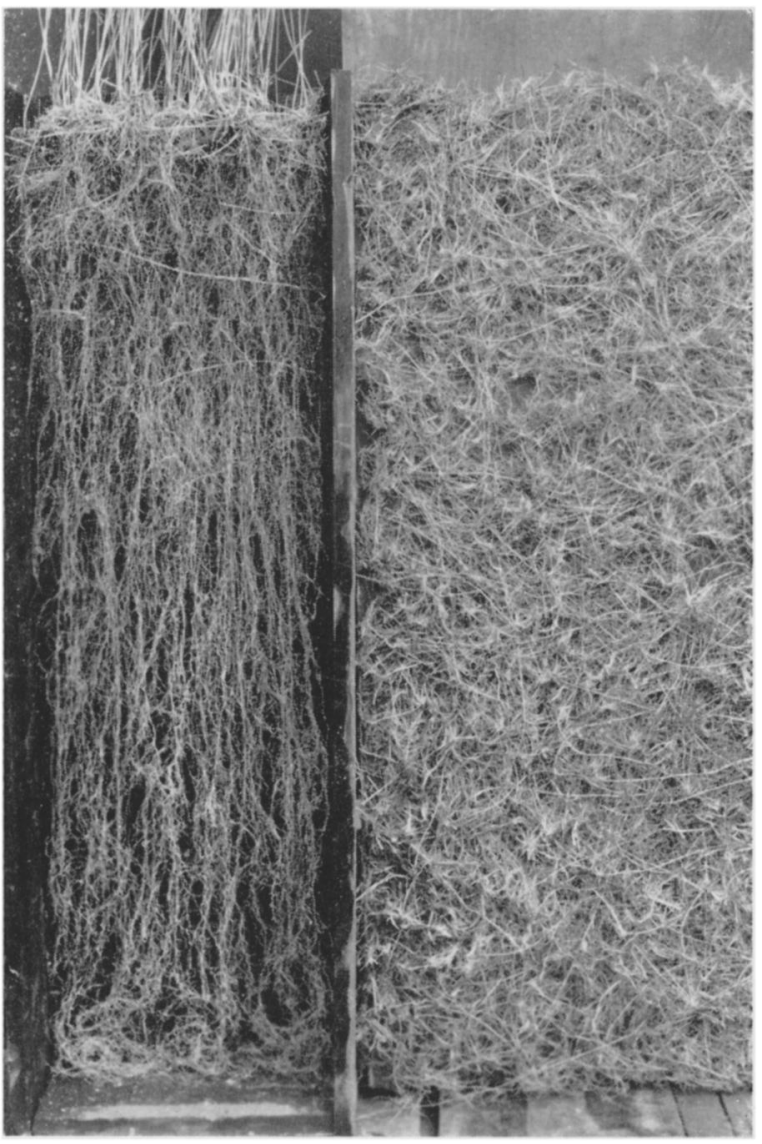

Fia. 14. (Left) Upper portion of the root system of western wheat grass growing in Carrington silt loam, washed from a soil monolith 12 inches wide, 40 inches deep, and 5 inches thick. (Right) Roots and rhizomes of this grass in the surface 10 centimeters of a halfsquare meter of soil. Excavations made by George A. Garrison.

of several mature plants of Lygodesmia juncea attained depths greater than 16 feet.

Roots of blue grama were examined in prairie in the same soil type about 2 miles distant. These roots were very similar to those of buffalo grass in fineness, branching, and depth of penetration. They were abundant in the limy, moist, loess subsoil to about 6 feet and the longest penetrated a foot deeper.

Roots of blue grama were also examined in Colby silt loam about 5 miles southeast of Broken Bow. They were from undisturbed native prairie. Depth of penetration was approximately 5.5 feet. They ended in a very moist, limy subsoil. Those obtained from a 3 - by 12 -inch monolith 4 feet deep are shown in Figure 15. It may readily be seen that the greatest concentration of roots was in the $A$ horizon (0-12 inches), but they were also abundant in the next 8 inches or B horizon. They were least abundant below 3 feet. From these studies and numerous other observations it seems clear that the important grasses are well rooted to depths of 4 to 6 or more feet, and that many of the forbs extend to much greater depths. 


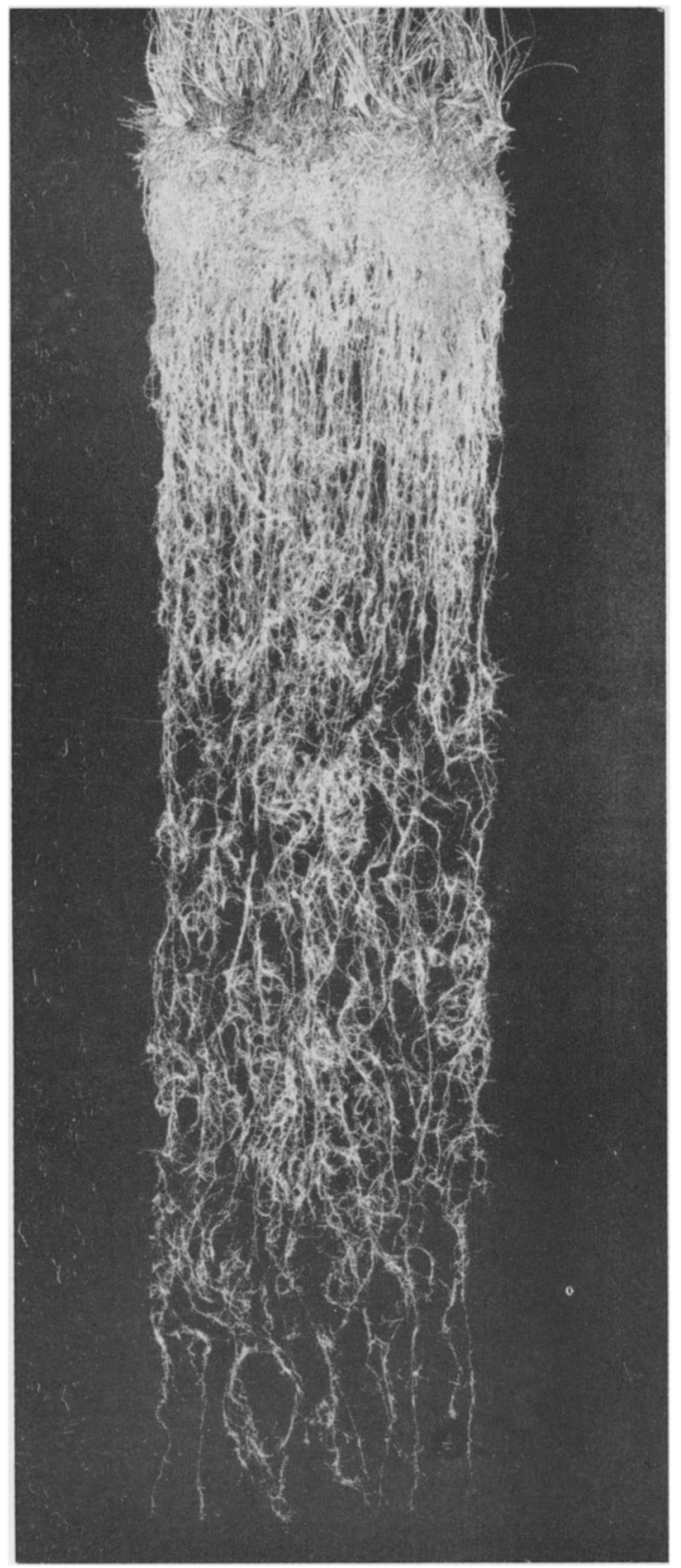

Fig. 15. Root system of a good stand of blue grama growing in Colby silt loam near Broken Bow, Nebr. Note the concentration of roots in the A horizon.

\section{EARLY SETTLEMENT AND LAND USE}

Although the first settlement in this grassland area was marle in Buffalo County in 1858 and the Union Pacific railroad was built in the Platte Valley just south of the loess bluffs in 1868, general settlement of the area (except by cattlemen) began considerably later. Prior to the coming of the cattlemen to Custer County in 1869-70, for example, most of the county was occupied by Indians who subsisted largely on wild game, fish, and fruit. But during the 4 or 5 years after 1870 , cattle grazed on the free open range, where a variety of nutritious grasses afforded good forage in summer and fair winter grazing. By 1872-74 the early settlers in the several counties located in the larger stream valleys where there was an abundance of fuel and water, but later settlement spread throughout the uplands. By 1890 most of the land was homesteaded and the fencing of range land became general. The rougher parts of the eroded loess plain are now held in large tracts by livestock farmers and ranchers, many of whom cultivate only a small portion of the land. But even very rolling land is used for growing corn, small grains, alfalfa and other crops (cf. Hayes et al. 1926).

Since the homesteads were relatively small (160 acres in area) and inadequate for a large herd of livestock, there seemed no choice in making a livelihood but to break the least rolling land and to grow farm crops. In many places this resulted in greatly accelerated erosion, the loss of the topsoil, and an extremely rough soil surface. More recently such fields were sown to sweet clover with the hope of increasing the nitrogen supply and aiding nature in her struggle to reclaim the soil. These lands are reclaimed very slowly, especially where grazing is practiced. A long subsere of annual weeds, shortlived unpalatable grasses, and perennial weeds may, after 15-30 years, be replaced by open stands of buffalo grass, sand dropseed (Sporobolus cryptandrus), western wheat grass, and other perennials. But the incomplete stands and meager yields reveal clearly that organic matter is still low and nitrogen supply is scarce.

The extent of the land in each county still under a cover of grass (nearly all native grasses) and the percentage that should be placed under grass, according to the Federal-State Soil Conservation and Survey Division, are shown in Table 5 .

Since portions of two of these four counties in the loess bluff region are adjacent to or covered in part by the sandhills, it is necessary in Table 5 to deal only with non-sandy soils. The total area of these counties varies from about 566 square miles (Sherman and Valley) to 2,588 square miles (Custer). Hence the areas in grass are very large. The first column in Table 5 shows that about a fourth to nearly a half of these counties are still natural grassland. The large percentages recommended for a grass

TABLE 5. Percentage of uncultivated land, total non: sandy uplands in grass, and total non-sandy uplands recommended to be placed under grass. Percentages are based on the area of the county.

\begin{tabular}{c|c|c|c}
\hline \hline County & $\begin{array}{c}\text { Uncultivated } \\
\text { land (exclusive } \\
\text { of riverwash } \\
\text { and sand } \\
\text { hills). Nearly } \\
\text { all grassland }\end{array}$ & $\begin{array}{c}\text { Total non- } \\
\text { sandy uplands } \\
\text { in grass. } \\
\text { Dominant } \\
\text { slope more } \\
\text { than 10 } \\
\text { percent }\end{array}$ & $\begin{array}{c}\text { Total non- } \\
\text { sandy uplands } \\
\text { recommended } \\
\text { for grass }\end{array}$ \\
\hline Buffalo.... & 25.9 & 14.3 & 32.5 \\
Custer.... & 44.9 & 38.2 & 47.4 \\
Valley..... & 48.3 & 41.5 & 51.4 \\
Sherman... & 43.6 & 39.4 & 60.8 \\
\hline
\end{tabular}


cover indicate clearly that the sod of extensive tracts in the uplands should never have been broken. Iikewise, the 14 to 42 percent in grass where the prevailing slope is greater than 10 percent indicates clearly the nature of the topography.

\section{NATIVE VEGETATION}

The mixed prairie of the Central Nebraska Dissected Loess Plains differs from the true prairie adjoining it on the east in many ways. An outstanding difference is the presence over the entire area of short grasses, predominantly blue grama, which cover the drier portions of the uplands in more or less pure stands, and alternate with mid and tall grasses, or form an understory beneath them (Figs. 16 and 17). Buffalo grass suffered heavy losses during the great drought (1933-40) and is now absent or occurs sparingly in many ungrazed tracts. This area of mixed prairie is further characterized by considerable amounts of plains muhly (Muhlenbergia cuspidata), purple three-awn (Aristida pur-

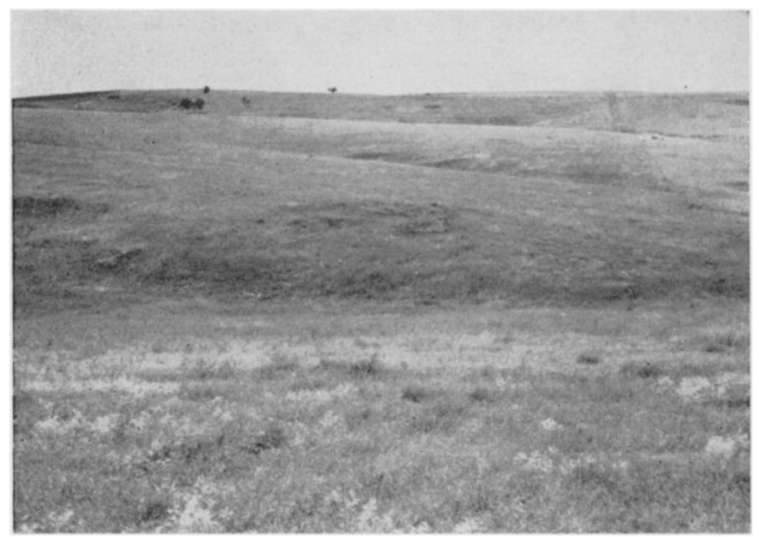

FIG. 16. A half section of ungrazed mixed prairie south of Litchfield. This unfenced prairie was adjacent to a large pasture on the right. The foreground is mostly blue grama with hairy chess. Trees in the background had been planted, but the homestead was abandoned long ago.

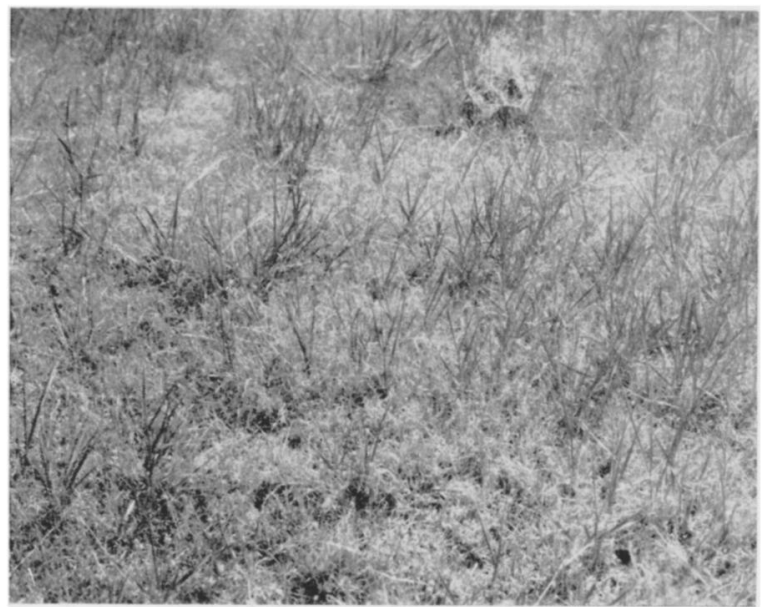

FIG. 17. Typical mixed prairie consisting of a lower layer of short grasses and an upper layer of a mid grass (western wheat grass).

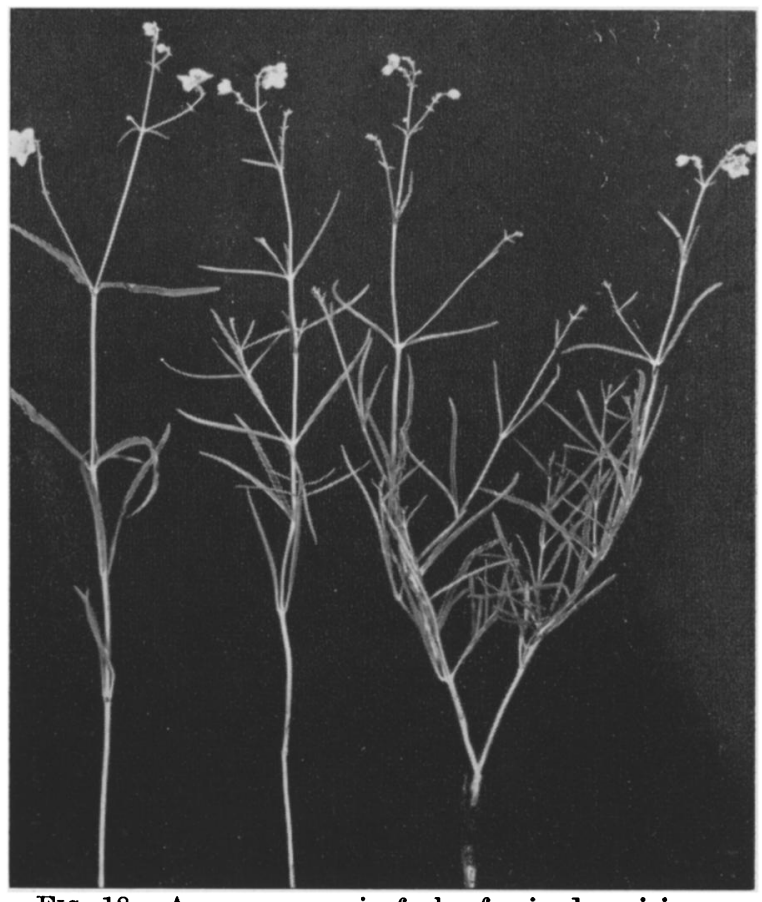

FIG. 18. A common xeric forb of mixed prairie, narrow-leaved four-o'clock (Allionia linearis).

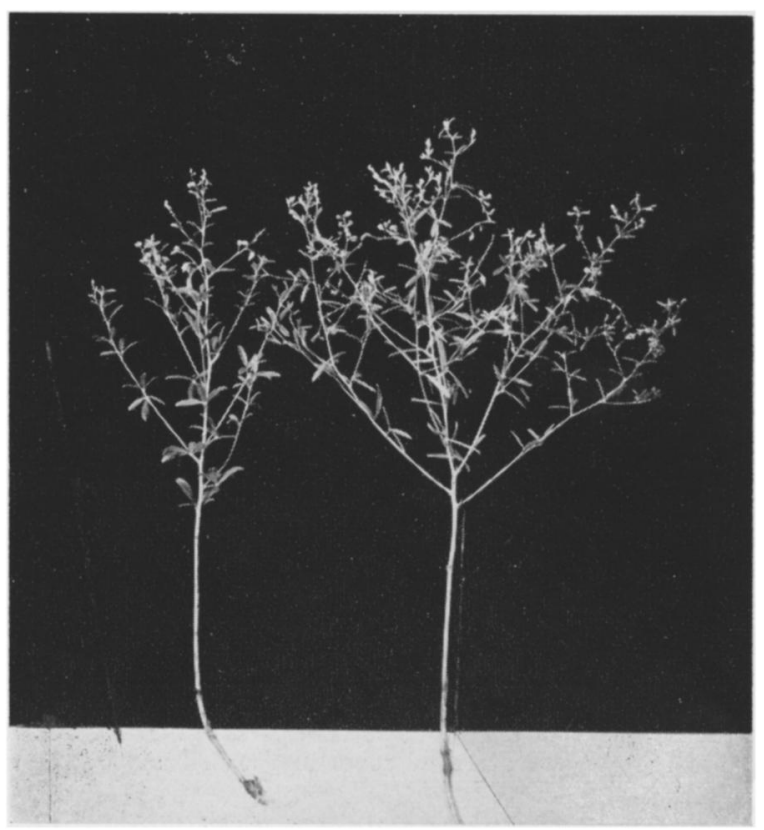

Fig. 19. Plants of few-flowered psoralea (Psoralea tenuiflora). This species is often abundant in both prairie and pasture.

purea), and red three-awn (A. longiseta), sand dropseed, and especially large amounts of western wheat grass. All of these grasses were rare in the true prairie eastward before the great drought (Weaver \& Fitzpatrick 1934). Sand dropseed became very abundant in true prairie during the drought but is now largely displaced by more mesic grasses (Weaver $\&$ Bruner 1945). The eastward invasion of western 
wheat grass has resulted in profound changes in true prairie; it is disappearing only slowly (Weaver 1942, 1948). Conversely, several species of grasses abundant eastward were not found or were rare. Among these were prairie dropseed (Sporobolus heterolepis), needle grass (Stipa spartea), and slough grass (Spartina pectinata).

This loess bluff area is also characterized by a large number of xeric western forbs which occur sparingly or not at all in the western margin of true prairie. The following are examples: Sideranthus spinulosus, Malvastrum coccineum, Gaura coccinea, Chrysopsis villosa, Cirsium ochrocentrum, Allionia linearis, Solidago mollis, Geoprumnon plattense, Astragalus lotiflorus, Neomamillaria vivipara (Nutt.) Britton \& Rose, and Thelesperma gracile (Figs. 18, 19, and 20). Conversely, numerous species common on uplands of eastern Nebraska occur here only rarely or not at all. Among these the following are examples: Helianthus rigidus, Euphorbia corollata, Liatris scariosa Willd., L. pycnostachya Michx., Coreopsis palmata, Meibomia canadensis, M. illinoensis, Baptisia bracteata, and B. lencantha. Psoralea tenuiflora has replaced $P$. floribunda.

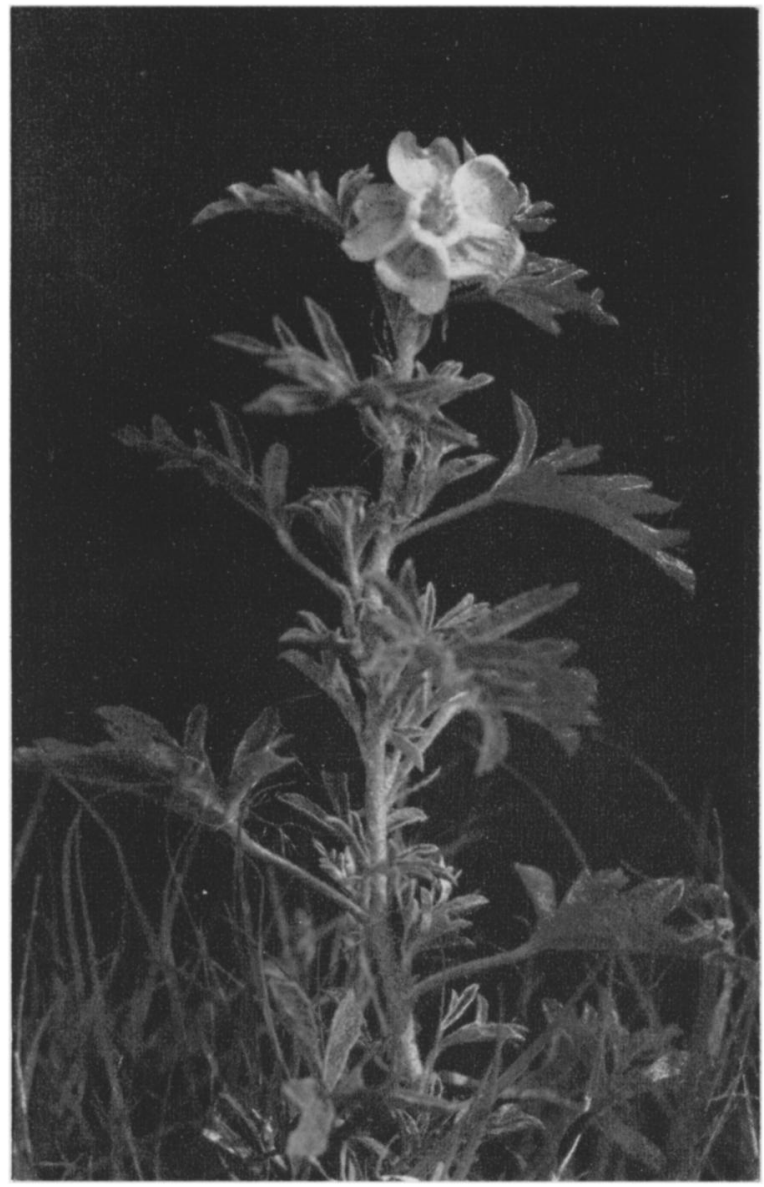

Fig. 20. Detail of red false mallow (Malvastrum coc cineum.). This is the most drought resistant forb of mixed prairie. It occurs in greatest abundance intermixed with the short grasses.

\section{COMMUNITIES OR TYPES OF PRAIRIF}

Every considerable sample of the mixed prairie included four types. These were the short-grass, mid- and tall-grass, and western wheat grass communities, and a fourth type where the preceding were more or less intermixed. The short-grass type was most extensive, at least since the great drought, hence it is described first. The former mid-grass type has become considerably modified to a mid- and tall-grass community, especially since 1933, by the great spreading of big bluestem (Andropogon furcatus) following the heavy losses of little bluestem (A. scoparius). On the whole, the mid-grass type has undoubtedly become restricted to much less than its former area. As to the extension of western wheat grass over great areas formerly occupied by other grasses, the evidence is overwhelming that this has occurred here just as it has taken place in the western portion of true prairie (Wearer \& Albertson 1943).

\section{Short-Grass Type}

The most important eharacteristic of this community was the fact that the short grasses dominated usually in almost pure stands or even where there was an intermixture of taller grasses such as sideoats grama (Bouteloua curtipendula). A second characteristic of great importance was the fact that blue grama was far more abundant than buffalo grass. The latter was often entirely lacking or, if present, it nearly always occurred as a species of less importance in virgin, ungrazed prairie. In fact, its abundance was often a sign of disturbance at some previous time and, as will be shown, its amount where it was present increased with grazing until the result was a buffalo grass range. It was more apt to be found, at least in abundance, in prairies adjacent to old buffalo grass pastures than in large areas of well managed ranges.

Causes of the present greater abundance of blue grama were twofold. This species was harmed much less by severe drought, and, because it is a little taller, it endured shading caused by rank growth of vegetation much better than buffalo grass. Such luxuriant growth of both weeds and native plants occurred during 1942-47.

In the drier portions of most prairies there usually existed a rather dense sod-mat of blue grama or of this species intermixed with or sometimes alternating with rather extensive patches of buffalo grass. These sites usually included slopes where runoff was high but they were not necessarily those most exposed to sun and wind (Fig. 21). Many north-facing slopes or those facing east and north were carpeted more or less entirely with short grasses. Conversely, areas of short grasses even on dry south and southwest slopes were often divided into belts or patches by the presence of narrow to wide bands of mid grasses on catsteps. Mid grasses also occurred just below the upper borders of ravines where there was an accumulation of runoff water.

Location and extent of the short-grass type was 


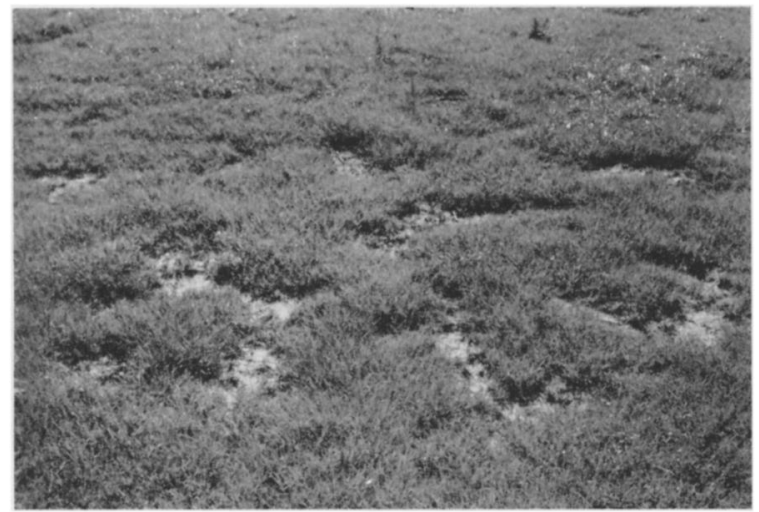

Fig. 21. Blue grama and buffalo grass on a hilltop where drought had opened the cover. The bare areas are not yet all reclaimed. Photo June, 1945.

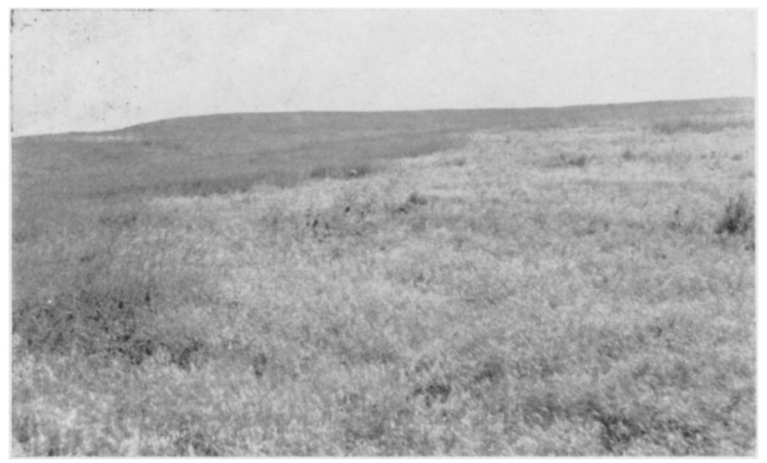

Fug. 22. Portion of an extensive east-facing slope coverel with blue grama overtopped by hairy chess. The prairie to the left consists largely of western wheat grass. Photo July, 1947.

usually set in sharp relief by the ever-present overtopping layer of the weedy annual, hairy chess (Bromus commutatus). It was a well established invader that became abundant during the years of drought. The matured stand of short grass had foliage 4-8 inches tall but it was always overtopped by the panicles of hairy ehess which dried in place and became almost white in mid and late summer (Fig. 22). Sometimes this brome alone occupied otherwise bare soil. In the alternes of mid and tall grasses (including western wheat grass) hairy chess often occurred, but even if abundant it was far less conspicuous because of its relatively lower stature. How long this brome will persist is unknown. It has greatly decreased and often entirely disappeared under the thick stands of mid grasses in true prairie.

Species of secondary importance intermixed with the short grasses included hairy grama (Bouteloua hirsuta), purple three-awn, red three-awn, plains muhly, and sand dropseed in the more xeric category. Side-oats grama, June grass (Koeleria cristata), and Scribner's panic grass (Panicum scribnerianum) formed an intermediate group, and big bluestem and nodding wild rye (Elymus canadensis) were chief among the taller grasses. An understanding of this phenomenon can be had only by considering the drought. Some of the steep ridges and driest slopes even today-after 6 or 7 years with good rainfall-are clothed chiefly with large bunches of blue grama so widely spaced that half of the soil is bare. During the 7-year drought, whole hillsides and even level hilltops were laid bare of vegetation or nearly so. It was at this time that the predrought dominant, little bluestem, largely disappeared. Much territory dominated by it and its associates was claimed during drought by short grasses, particularly blue grama, for this species was the most drought-enduring grass of all. During moist springs of certain years of drought this species flourished and spread widely. There was a gradual gain among short grasses (and also of western wheat grass) while most other species waned. Hence today many of the preceding relict grasses are intimately mixed with short grasses.

\section{Mid- and Tall-Grass Type}

On the lower slopes of the hills and in the ravines, which mostly have broad flat bottoms, there are environments favorable for the development of midand tall-grass vegetation (Fig. 23). Many ravines have banks with slopes which reach a vertical distance of 10 to 25 feet above the level bottom. These are partially protected from wind and sun and in addition they receive much runoff water from the surrounding upland. Where the eroding valleys have cut far back into the bluffs, such places may occur not far from the hilltops. Typically there is no drainage ditch to interfere with the mowing of the vegetation for hay (Figs. 24 and 25). Locally such places are known as "hay pockets" since the yield is much greater than that on the bluffs.

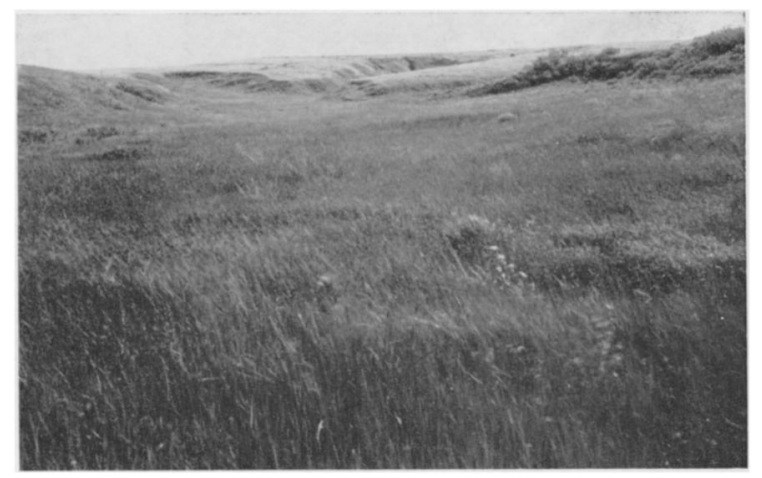

FIg. 23. Community of mid and tall grasses in a flatbottomed ravine where snow and runoff water from the slopes increased the water content of the soil. Note the bordering shrubs (right) on the north-facing slope.

Where the soil had slumped to produce eatsteps on the hillsides, vegetation was of much the same type as in the valleys and ravines (Fig. 26). Here the relict little bluestem, usually scattered but sometimes dense locally, represented the remnants of the former stands of this predrought dominant. But big bluestem was the chief dominant in all such places as it was also in streaks and patches on moist, protected hillsides.

The sod-forming big bluestem had spread widely and often thickened its stand to the exclusion of both 


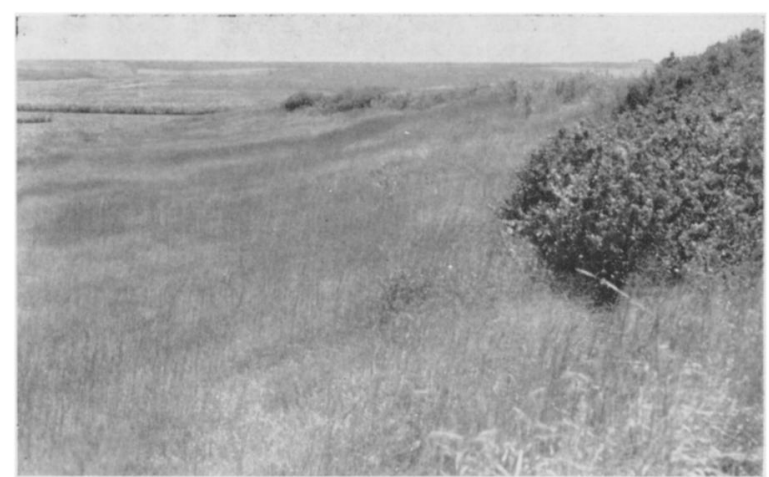

Fig. 24. Big bluestem (dark), Indian grass (Sorghastrum nutans), and mid grasses on the floor and sides of a shallow ravine near Amherst in August, 1947.

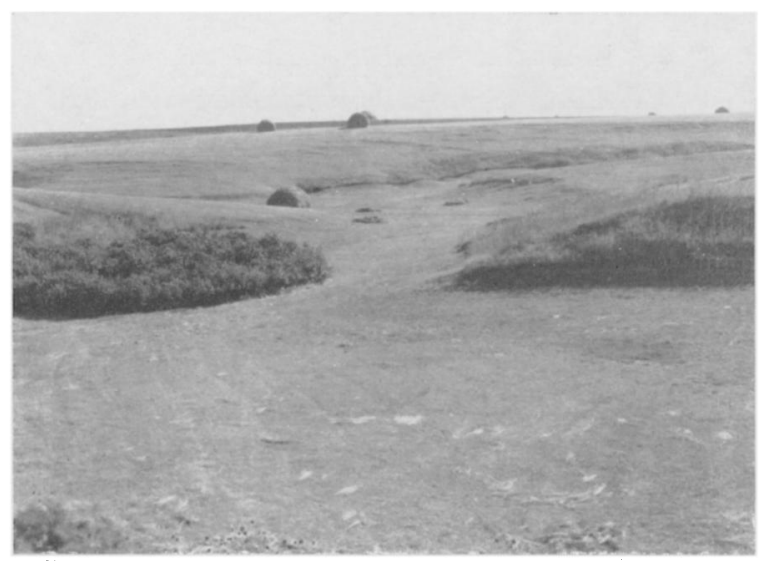

Fig. 25. A native prairie mowed for hay in August, 1947. It is about 27 miles north of Elm Creek. Prairie grasses remain undisturbed on the banks that are too steep for mowing. Some banks (left) are covered with shrubs.

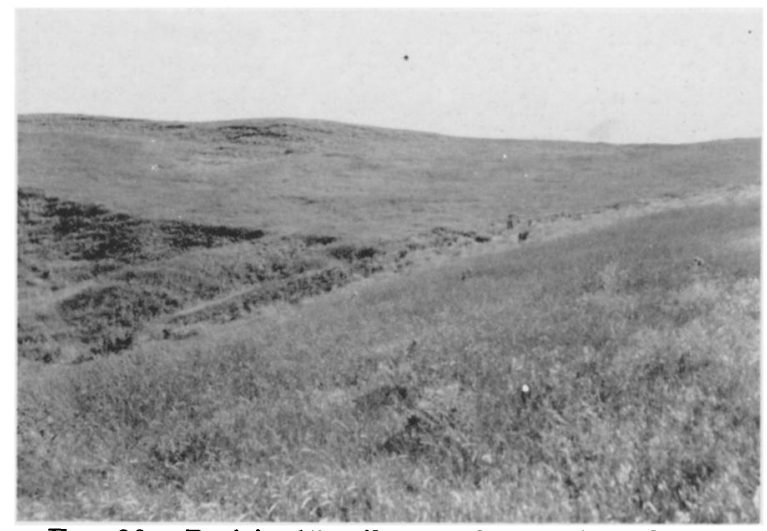

FIG. 26. Prairie 15 miles southeast of Broken Bow showing catsteps on the steep banks of a ravine (left) and on the hillside in the distance. Here the mid- and tall-grass type of prairie prevails. Relict little bluestem was common.

short and mid grasses. Nodding wild rye was common here and there in these moist areas as was also switchgrass (Panicum virgatum), especially in the valleys. A stand of switchgrass indicated the best water supply. Nodding wild rye was found in greatest abundance where disturbance had occurred, as by the deposit of soil in a ravine. Indian grass (Sorghastrum nutans) was usually not abundant and slough grass was rarely found. Several coarse carices as Carex gravida, C. brevior (Dewey) Mackenzie, and others, were often more or less plentiful. Postclimax tall grasses sometimes occurred, each in pure stands, but often they were intermixed. Kentucky bluegrass (Poa pratensis) intermingled with nearly all of them. In this type, short grasses were practically excluded.

On the sides of the ravine above the reach of the mower, the mulch of dead big bluestem was often 5 to 10 inches deep, since the prairie was rarely burned intentionally. In this debris, which was sometimes more than a foot deep, one could readily distinguish three crops of dead plants-two of decaying leaves and one of leaf mold-under the living grasses. This accumulation of material prevented the development of an understory, greatly delayed development in spring, and thinned the new stand of big bluestem or other tall grasses to about one-third the usual number of stems.

The second most abundant grass was side-oats grama. It occurred widely and often in nearly pure stands on the catsteps and banks above the steep slopes of the ravines, or in patches in the valleys (Fig. 27). Like the other mid grasses it alternated with the rankly developed tall grasses or intermingled with them. June grass, plains muhly, and tall dropseed (Sporobolus asper) were of common occurrence.

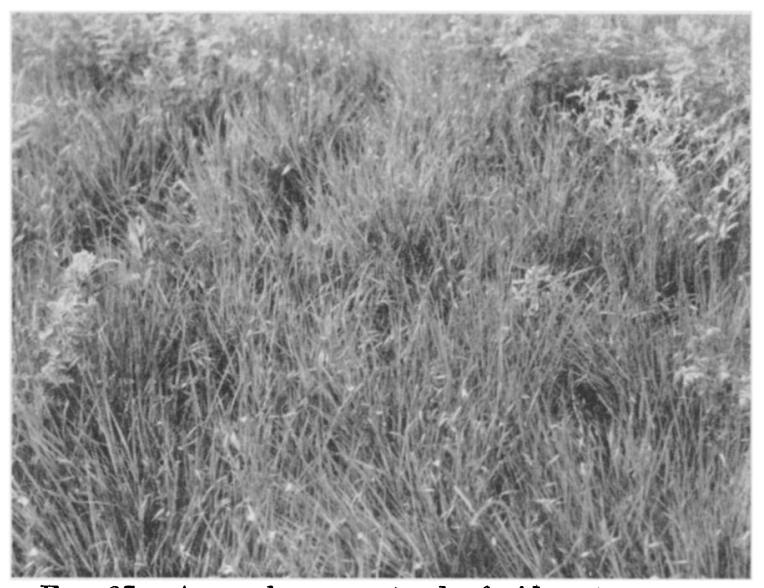

FIG. 27. A nearly pure stand of side-oats grama on a steep slope near a ravine. Small amounts of hairy chess are intermixed.

Relict needle grass was rarely found. Kentucky bluegrass was often well represented in the understory as were also Scribner's panic grass, Wilcox's panic grass (Panicum wilcoxianum), and penn sedge (Carex pennsylvanica). Bluegrass, as in true prairie, had made enormous gains during a wet cycle following the drought. It was not uncommon to find it in almost pure patches in ravines and on normally dry slopes growing side by side with blue grama. It was commonly intermixed with various mid grasses. The two smaller panic grasses often occurred in pure stands in small patches formed during drought. Patches of western wheat grass were common and 
indeed abundant where this drought-evading species had replaced the other grasses. Where the cover was open, sand dropssed was frequently found. Hairy chess occurred more or less abundantly, being thinner or absent where the shade was denser. It was thickest where damage by drought was greatest. In small patches it still constituted practically the only vegetation.

\section{Mixed Short and Taller Grasses}

In addition to the short-grass type and the much more mesic one composed of tall and mid grasses, there were transitional areas of considerable extent where species from the two types grew more or less in equal abundance, forming the characteristic layered vegetation of mixed prairie. Big bluestem with an understory of blue grama, and less often buffalo grass, was a product of the drought (Fig. 28). When the formerly abundant little bluestem largely succumbed, big bluestem, intermixed with it, often survived, partly because of its deeper root system but often because of its rhizomes. These are known with certainty to have remained dormant 5 to 7 years both in true prairie and in mixed prairie (Weaver \& Albertson 1944, Weaver \& Bruner 1945). During the least severe of the years of drought much big bluestem spread widely. This spreading was accelerated when the rains finally came and the thin stands thickened greatly. Likewise the short grasses invaded much territory formerly occupied mostly by little bluestem but also by smaller. amounts of big bluestem. This also resulted in the apparent anomaly of the short grasses forming an understory to the postclimax big bluestem in many sites.

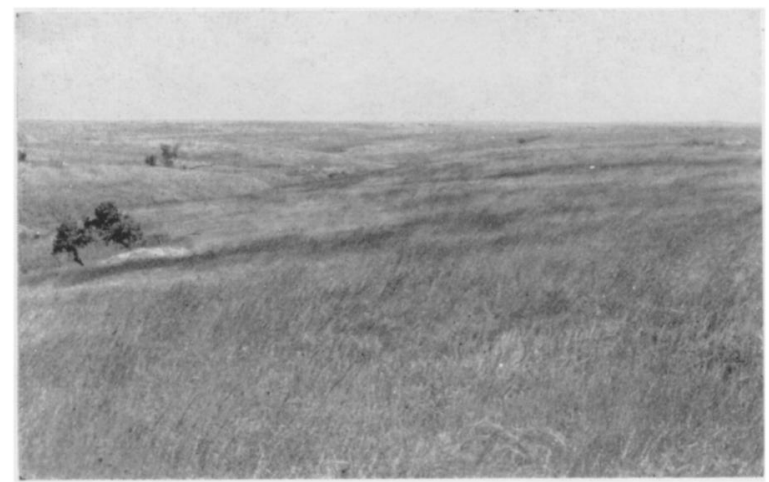

FIG. 28. A square mile of mixed prairie about 10 miles southwest of Ansley, showing belts and streaks of big bluestem (dark), frequently with an understory of blue grama. The lighter colored portions are hairy chess intermixed with short grasses and several species of mid grasses. Photo August, 1947.

Side-oats grama developed vigorously, produced abundant seed crops, and spread very widely during drought, when released from severe competition of other grasses. It was intermingled with the short grasses orer vast areas. Sand dropseed was still abundant in the driest situations along with the short grasses but it was much less abundant than side-oats grama. Some relict little bluestem, rapidly increasing in amount, was intermixed with the short grasses. Purple three-awn, plains muhly, June grass, and bluegrass taken together sometimes bulked large. Often there was about an equal mixture of mid grass overtopping the short grass.

Areas in true prairie where whole hillsides were almost bared of vegetation by drought were repopulated by half a dozen dominant species in about equal numbers. They formed a complete cover, but not enough time had elapsed for the usual prairie types to develop. This was also true in considerable portions of mixed prairie. The vegetation was simply a mixture of all the grasses that chanced to survive or migrate quickly while there was room for all. These unstable communities are best described as merely a mixture of grasses. They did not occur before the catastrophe of great drought.

\section{Western Wheat Grass Type}

The extensive spreading of western wheat grass during the period of drought has been remarkable. In true prairie eastward it made a phenomenal increase from a species of very minor importance to one of first rank. "Immediately after 1934, it became increasingly abundant in true prairies and native pastures. It has continued its spread over all types of terrain wherever bared places or open stands of other grasses had resulted from the terrible drought" (Weaver \& Albertson 1943). Western wheat grass was found in greater or lesser amounts in every prairie examined. Since dust deposits often aided considerably in its invasions, it was usually very abundant where prairie was adjacent to cultivated land. In amount it varied from almost complete replacement or overtopping of other vegetation, through extensive alternes in short grass or other prairie grasses, to patches so small or stands so thin that they had little effect upon the prairie cover as a whole. Moreover, distribution had no relation to type of soil, slope, or exposure. It was found on valley floors, on both gentle and steep slopes, and on hill crests and catsteps. Amount and extent were entirely unpredictable, but were probably related to such factors as direction and velocity of wind, bareness of slopes, and abundance of seed supply. It rarely if ever replaced established vegetation. Its distribution and abundance may best be explained by a few examples.

About 10 miles northeast of Hazard there occurs a quarter section of nearly level land except for several deep ravines which have worked half way across the tract from the east side. The unbroken eastern half, which had been clothed with a cover of mid and short grasses, had become, by July 1947, a sea of dense western wheat grass with foliage nearly 2 feet high and abundant spike-topped flower stalks 3 feet tall. Great dust storms and drought had resulted in the death of practically all of the former vegetation. The area closely resembled a field of ripening grain. It differed, however, in an almost continuous understory of hairy chess, 15 inches high, and an intermittent lower layer of Ionoxalis violacea. 
Forbs were few and entirely confined to Solidago mollis, Lygodesmia juncea, and other species of great drought resistance. Only rarely was a small "island" of blue grama seen.

A much smaller portion of the area differed only in that an understory of blue grama occurred beneath the western wheat grass. Although western wheat grass also completely clothed the banks and bottoms of some ravines, the original communities of tall grasses and mid grasses remained intact and were flourishing elsewhere. All the prairie grasses usually found in such sites were plentiful and in addition a wealth of lowland and upland forbs remained. This presented a striking contrast to the monotonous cover of western wheat grass. The only other vegetation was thickets of shrubs and vines. A similar prairie of western wheat grass is shown in Figure 29.

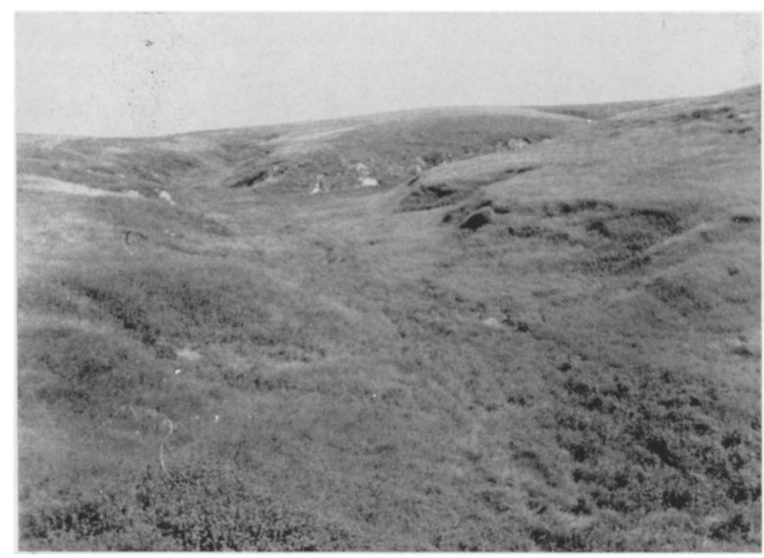

Fig. 29. Prairie 15 miles west of Loup City where the chief dominant everywhere is western wheat grass. Aside from patches of buckbrush (Symphoricarpos occidentalis), even the ravine is covered with this grass.

Another example of the invasion of western wheat grass was shown on a grand scale in a prairie approximately 15 miles southeast of Broken Bow. This whole range of 160 acres, except an east-facing slope, had been taken over by western wheat grass (Fig. 22). Drought had been prolonged and intense, for over much of this part the relict blue grama occurred only in widely spaced bunches. There was a continuous cover of hairy chess in which there were many species common under great disturbance, as six-weeks fescue (Festuca octoflora hirtella), little barley (Hordeum pusillum), horseweed (Leptilon canadense), Pursh's plantain (Plantago purshii), and sand dropseed. Drought-formed patches of penn sedge, Scribner's panic grass, and involute-leaved sedge (Carex eleocharis Bailey) were present, but no buffalo grass. The cover varied from nearly bare soil to 75 percent blue grama. Relict little bluestem occurred plentifully along the catsteps in stands 80 percent pure near the very tops of the high hills (Fig. 26). The little bluestem type must have extended far down the slopes, since the invading western wheat grass had no understory of relict blue grama. There was only a dense stand of wheat grass with an abundance of hairy chess. Forbs likewise had practically disappeared. This seemed due to the deposition of a layer of dust from fields to the south and west. Great bunches of relict blue grama crowned the tops of the hills. Here also reliet needle-and-thread (Stipa comata) grew thickly. The mid grasses on the uninvaded catsteps, wherever they occurred, grew luxuriantly and were intermixed with numerous prairie forbs.

A few miles west of Ord, a quarter section of mixed prairie was examined. It is described here because of the vivid manner in which it portrayed the mosaic of vegetation resulting from dust and drought. The topography was rough, steep hills being separated by deep ravines. Over much of the area western wheat grass had replaced most of the former vegetation. Description of the cover is that on a long hill running west of north and bounded on all sides except the north by deep ravines (Fig. 30).

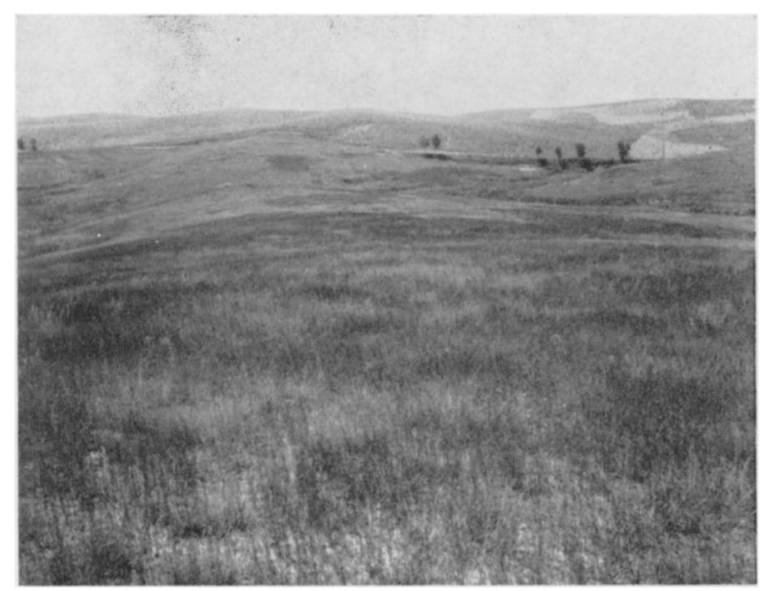

Fig. 30. View looking southeast from the top of a long hill several miles west of Ord. The deep east-west ravine separating this bluff from the one nearer the road with a single small patch of western wheat grass is obscured by the base of the hill. Note cultivated fields of maize on this rolling land. August, 1943.

The main axis was $1 / 4$ mile long. The south face was steep and much smaller than the very extensive east and west slopes.

Upon crossing the main ravine from the south one entered a continuous belt of almost pure western wheat grass on the nearly level lower part of the slope. This phenomenon of the death and replacement of big bluestem and its associates was rather common on such highly insolated areas where run-in water was normally plentiful in the lowland soil. The tall grasses had evidently not been rooted deeply enough to withstand extreme drought (Weaver \& Albertson 1943). Western wheat grass swept around the base of the hill both eastward and westward in a belt only a few yards wide. On the lower slope proper, there occurred a zone of big bluestem.

The bluestem vegetation, formerly continuous across the ravine, extended upward on south and east slopes above the western wheat grass for a few yards 
only. The foliage was 3 feet high and flower stalks were 6 feet tall. Examination made it clear that this grass had now rooted more deeply than formerly. Side-oats grama, growing with the bluestem, put forth flower stalks to the unusual height of 40 inches, thus giving evidence of the presence of abundant moisture.

Side-oats grama formed a distinct belt from a few to many rards wide on the upper banks where the more gentle slope of the hilltop gave way abruptly to a precipitous one. Here runoff was normally high and much erosion occurred. This grass either withstoor the terrible drought which swept the hill almost free of vegetation, or reseeded quickly from large relict bunches with the coming of favorable seasons. Actually both phenomena had occurred.

The long southwest slope, the hill top, and the east slope had practically lost their cover of mid and short grass during the early years of drought (1934-36). They were now a field of western wheat grass. An exception was a narrow belt of mixed big bluestem and side-oats grama fringing the east ravine. But across this ravine, western wheat grass recurred and swept over the adjacent hill and down to the next valley. Not only were all of the former grasses replaced but also all of the forbs, except a few of the most drought resistant, had succumbed.

The distribution of western wheat grass was not at all uniform in amount in different samples of prairie. Sometimes only a little was present. It often covered a single ridge or only a particular slope, or small patches only occurred in a ravine. Oftentimes a thin overstory was found or possibly a few dense patches. But not a single prairie was examined where western wheat grass was entirely absent. Streaks and patches, pure or intermixed with short grass or mid grass, were the rule where formed an upper story to the short grasses over more extensive invasion had not occurred. It probably area than any other species.

The several communities of the prairie vegetation have been described separately only for the purpose of clarity. The boundaries were often indefinite and fragments of one community frequently occurred as patches or islands in the others. The vegetation had undergone great changes due to drought and dusting and was in a stage of rapid recovery. Such stability as occurs between the longer cycles of severe drought has not yet been attained.

\section{Résumé of Grasses}

The grasses and sedges of the mixed prairie in this loess bluff region occurred in the following groups :

\begin{tabular}{lc}
\multicolumn{2}{c}{ Dominant SPECIES } \\
Short-Grass Type (Faciation) \\
Bouteloua gracilis & Buchloe dactyloides \\
Mid- and Tall-Grass & Type (Postclimax associes) \\
Andropogon furcatus & Panicum virgatum \\
Bouteloua curtipendula & Elymus canadensis \\
Agropyron smithii &
\end{tabular}

Mixcd Short and Taller Grasses ('Typical expression of association) $\begin{array}{ll}\text { Andropogon furcatus } & \text { Bouteloua gracilis } \\ \text { Bouteloua curtipendula } & \text { Buchloe dactyloide }\end{array}$ Bouteloua curtipendula Buchloe dactyloides Agropyion smithii

Western Wheat Grass Type (Consociation)

Agropyron smithii SPECIES OF SECONDARY IMPORTANCE

(Of greater abundance) (Of lesser abundance)

Muhlenbergia cuspidata Poa pratensis Loeleria cristata Sporobolus cryptandrus Panicum scribnerianum Carex pennsylvanica Sporobolus asper Anäropogon scoparius Panicum wilcoxianum A ristida purpurea A ristida longiseta Carex eleocharis Sorghastrum nutans Bouteloua hirsuta Schedonnardus paniculatus Stipa comata Stipa spartea

Hairy chess, as previously stated, was present to very abundant in every place where soil was exposed in sufficient amounts so that the seed could find lodgement and germinate, and where the seedlings were not completely suppressed by dense shade. This annual is a drought invader and not a permanent part of the vegetation. It is a seral dominant.

\section{Foris}

The great injury to grassland by drought and burial by dust was shown by the effect upon the population of forbs. Near the end of the drought the number of species generally distributed were few and most forbs had succumbed, were dormant, or were confined to the most protected sites. But during the several years following the drought nearly all reappeared from seed or dormant underground parts (Fig. 31). Their approximate importance is indicated in the following lists:

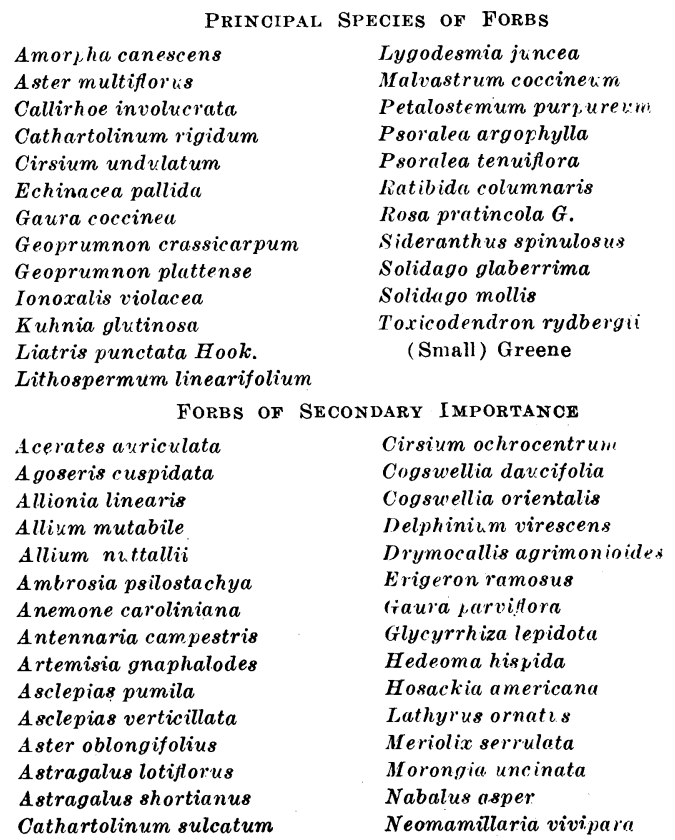


Oenothera biennis Onosmodium occidentale Opuntia humifusa Oxytropis lamberti Parosela enneandra Pentstemon albidus Petalostemum candidum Physalis heterophylla Physalis lanceolata Plantago purshi Polygala verticillata

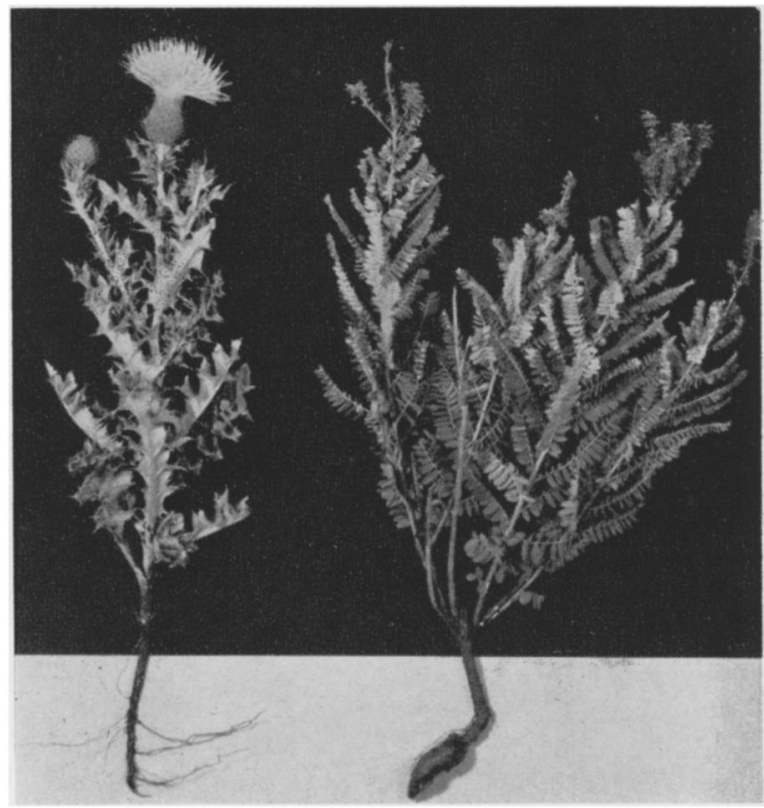

Fig. 31. Two common forbs of mixed prairie; wavyleaved thistle (Cirsium undulatum) left, and lead-plant (Amorpha canescens) right. Both spread by underground parts.

One of the most abundant, conspicuous, and widely distributed plants was the lead-plant (Amorpha canescens) (Fig. 32). Although it is a half-shrub it behaves as a forb under annual mowing. In abundance, it is an excellent indicator of grassland that has been ungrazed for a long time. It had increased greatly since the sod was opened by drought, and was often abundant in the short-grass type. Two other species which were not found so regularly but locally had increased enormously were the buffalo bean (Geoprumnon crassicarpum) and $G$. plattense. In numerous places single plants of buffalo bean were 3 to 4 feet in diameter (Fig. 33). Like aggregated mats of $G$. plattense, they grew so closely together that the soil was covered almost continuously over many square yards. Many other principal species of forbs as Callirhoe involucrata, Kuhnia glutinosa, Ratibida columnaris, Solidago glaberrima, S. mollis, and Psoralea tenuiflora formed societies of much greater density than the writers have ever before observed. This great increase in numbers of certain forbs was balanced by fewer numbers and greater localization of many others. Gaura coccinea, Sideranthus spinulosus and Lygodesmia juncea were representative of numerous other species which were

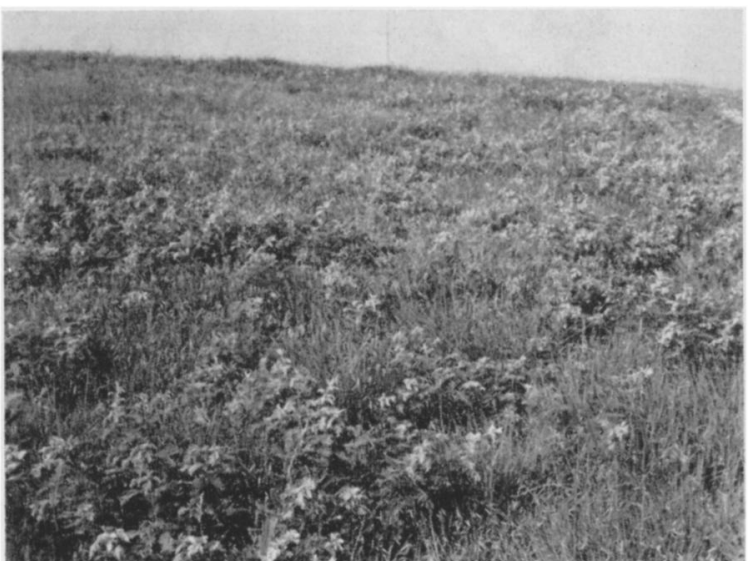

Fig. 32. Typical thick society of lead-plant in a mixed prairie area about five miles west of Loup City. Sideoats grama is the dominant; there is also much hairy chess.

found rather regularly but ordinarily in about their predrought abundance. Wherever western wheat grass occurred forbs were invariably few. This resulted from the use of water by the grass even to depths of 6 to 8 feet early in spring. The soil became dry and later awakening species often succumbed to the drought (Weaver 1942).

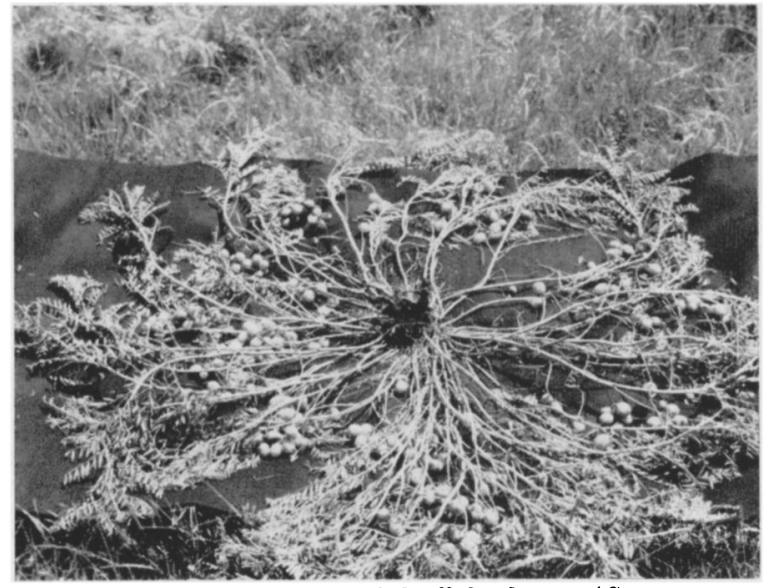

Fig. 33. Large plant of buffalo bean (Geoprumnon crassicarpum). The plant has been cut off and turned over to show the abundant fruits. The spread of this plant is about 4 feet.

\section{Shrubs}

The story of the distribution of the vegetation would be incomplete if the shrubs, vines, and small trees were overlooked. On the north-facing slopes especially, but also on other's partially protected from wind and sun, there often occurred fringing thickets of shrubbery (Fig. 23). For here, in addition to the rainfall, water runs in from the slopes above, and wind-blown snow accumulates. The shrubs were sometimes more or less intermixed with the tall grasses, but where they were well developed the grasses largely or entirely disappeared. These postclimax thickets consisted chiefly of buckbrush 
(Symphoricarpos occidentalis), choke cherry (Prunus melanocarpa), wild plum ( $P$. americana), and smooth sumac (Rhus glabra). Buckbrush often formed thickets on the valley floor as well, but its spread was usually held in check by annual mowing. Often the brush was 3 feet tall and so dense that even bluegrass was shaded out. Similar dense copses of the other species which grow much taller (10 to 15 feet) were almost without undergrowth. Other shrubs were golden currant (Ribes aureum Pursh), gooseberry (Ribes gracile Michx.), poison ivy (Toxicodendron rydbergii), and lead-plant, which reached a height of 3 to 4 feet. The prairie rose (Rosa pratincola) was represented by large bushes, and fox grape (Vitis rulpina) climbed over the shrubs. Sometimes small trees of white elm (Ulmus americana) occurred or those of boxelder (Acer negundo) and ash (Fraxinus pennsylvanica), but trees were more commonly found only along streams. Various mesic herbs as Helianthus tuberosus, Monarda mollis, and others not mentioned in the list of prairie forbs also occurred here.

\section{PASTURES}

This great tract of mixed prairie has been used chiefly for grazing. Considerable areas have retained their native cover, except that it is annually mowed for hay that is fed to livestock in winter. But by far the larger part is used for summer range, chiefly for cattle. Livestock is sustained by the range grasses from spring until late fall, and sometimes parts of the pastures are used only for winter grazing. Under continued grazing there are many changes in the composition of the vegetation even under good range management, and much degeneration of the grassland occurs under close grazing and trampling (Weaver \& Hansen 1941).

\section{EARLY SURVeY}

A survey of many ranges in the northern and western portions of the area was made in 1943, about 2 years after the great drought. The ranges varied in size from 80 acres to a square mile or more (Fig. 34). These mixed-prairie pastures consisted chiefly of blue grama although buffalo grass was found in moderate amounts, and it was abundant in old, closely grazed pastures (Fig. 35). Big bluestem was the chief tall grass; side-oats grama was of much less abundance except on the catsteps and steep banks. Western wheat grass occurred sparingly to abundantly, having populated many droughtbared or dusted areas regardless of slope or topography. In general, the ranges were not overgrazed, in fact most were moderately utilized, and some had not been pastured or at least had been grazed only intermittently since the great drought. For then herds of cattle were depleted and they had not been built up again.

The drought (and sometimes burial by dust) had left its marks of destruction almost everywhere, except perhaps on portions of well protected northfacing slopes. Excessive grazing also had sometimes played a part in weakening the grasses before

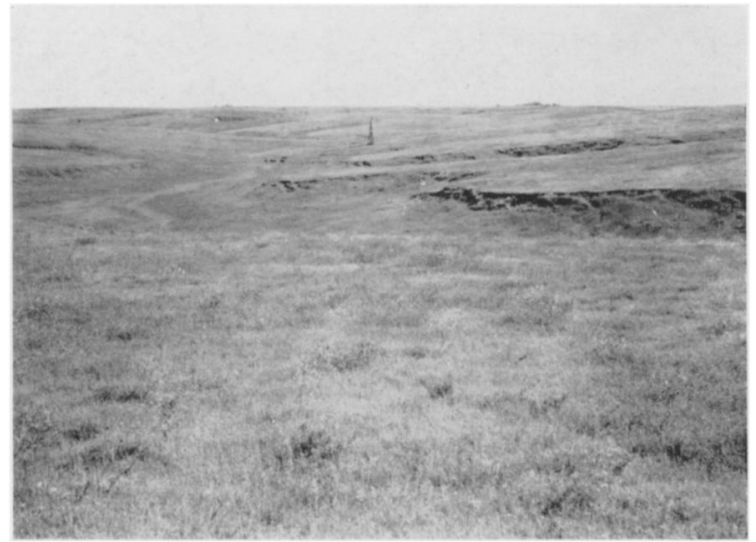

FIG. 34. Broad expanse of range land, looking north from a hilltop in the Sheen pasture near Kearney.

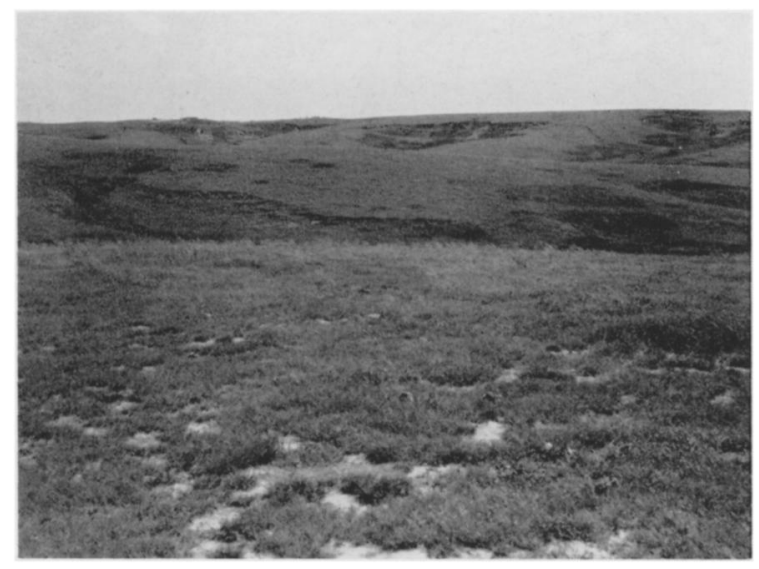

Fig. 35. Prairie reduced to short-grass pasture. Only in the ravines, which erode laterally, and up their steep sides were many relict mid grasses found.

drought occurred. Although a few greatly damaged ranges were still in the early or medial stages of a subsere, most of them were well on the way toward the reestablishment of a short-grass cover. The weedy stages had been succeeded by those of perennial grasses - often sand dropseed or western wheat grass-but mostly by blue grama.

In numerous places near the periphery of the main range area, pastures had not only been heavily grazed but also subjected to considerable dusting from cultivated fields. The hilltops and slopes had been nearly bared, except for relict bunches and patches of blue grama and remnants of buffalo grass in the most sheltered places. The buffalo grass returned quickly after 1940 and had occupied most of the area; even the hilltops and ridges were again twothirds covered. Relict plants and small patches of big bluestem, little bluestem, side-oats grama and a few other mid grasses were common on the protected banks (Fig. 36). Where the dust was deep, patches and streaks of ruderals occurred.

In most ranges the cover had been greatly disturbed by drought. Even on north-facing slopes drought or dust coverage had been so severe that considerable amounts of western wheat grass grew 


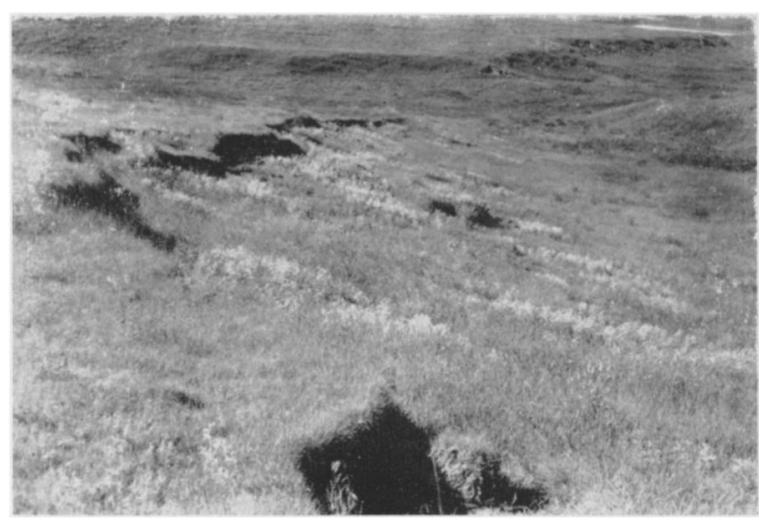

FIG. 36. Eroding soil where the hillside slopes give way to the steep banks which border the ravines. Note the good cover both in the ravine and on the hillsides. The light colored vegetation is a society of silvery psoralea (Psoralea argophylla).

in patches and alternes. Blue grama had reestablished a fairly good cover elsewhere; buffalo grass was present mostly on the level upland though only in small amounts. The basal cover of the short grasses was frequently only 50 percent. Relict sand dropseed was common, sometimes in alternes; purple three-awn occurred on bared slopes, and dried and lodged downy brome (Bromus tectorum) and hairy chess formed an excellent mulch in some local, half-bared places. There were few weeds. Only relicts of earlier subsere species remained. Lower slopes near deep ravines were well clothed with both big blustem and little bluestem below the usual distinct belt of side-oats grama on the sharp break from hill to ravine. This distribution of vegetation on hilltops, slopes, and ravines was repeated again and again in various ranges.

The ranges on the loess hills in the vicinity of Broken Bow were so similar (except those greatly overgrazed) that a single description will suffice (Fig. 37). They were dominated by blue grama; buffalo grass, where present, occurred in small amounts. The cover had been greatly depleted by drought since the normal precipitation of 23.1 inches decreased to $13.1,16.0$, and 17.9 inches in 1934, 1936, and 1939, respectively. Since there occurs here a rather large and almost continuous area of range land, dusting had been at a minimum.

Because of the rugged topography, there were many protected slopes and ravines in which the mid and tall grasses were thriving and frequently dominating to the exclusion of short grasses. These occurred even on southern exposures provided there was enough run-in water. Chief among these grasses were big bluestem, side-oats grama, little bluestem, nodding wild rye, and switchgrass. But the extent of the lowlands and ravines dominated by this tallgrass community had been greatly reduced by the drought. The less mesic portions had been repopulated by mid and short grasses. Side-oats grama, which is the most xeric of the preceding species, had usually not played its important role as in true prairie in reclaiming drought-bared soil. Where the

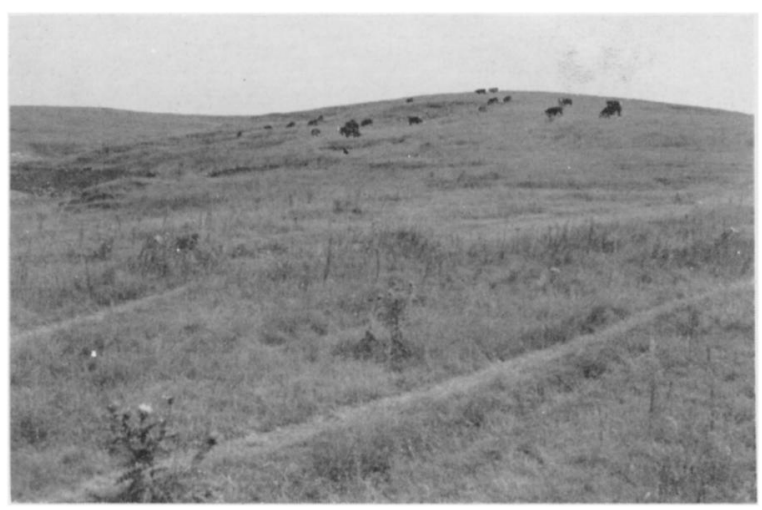

Fig. 37. A hillside on loess bluffs between Broken Bow and Lexington. This is a small part of a range several hundred acres in extent.

ravines had broad flat bottoms and were well grazed, the cover was short grass, mostly blue grama. Weeds were not abundant. In general the succession following drought was in the late stage and approaching such stability as is maintained under grazing.

Growth of seedlings and best development of blue grama by tillers had often been retarded by an accumulation of debris resulting from light stocking or complete protection. Where alternes of wheat grass occurred they were scarcely grazed or entirely neglected by stock if other forage was plentiful. Sometimes the deep debris from the growth of two or more seasons' crops had accumulated and hindered rapid succession (Fig. 38).

In these ranges, June grass, plains muhly, purple three-awn, hairy grama, and tall dropseed were all found but usually in small amounts and they were never abundant, except locally. Needle grass was rare. Plains muhly had generally increased during the drought but red three-awn and purple three-awn were now recovering from nearly complete extinction. Tumble grass (Schedonnardus paniculatus) was a common indicator of disturbance. Its dried panicles lightened the hillsides where the cover of blue grama had been well opened by drought.

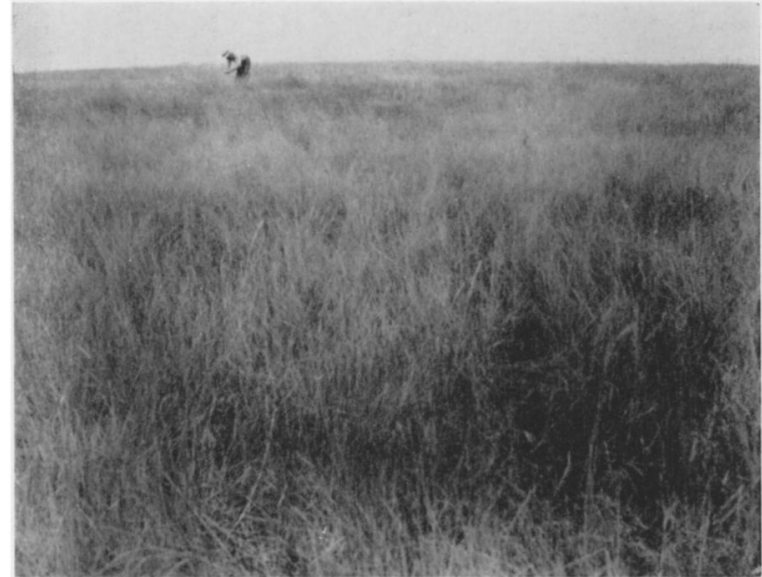

Fig. 38. A north slope covered with a dense stand of western wheat grass. Vegetation of preceding years is lodged here and forms a deep mulch. Unlike the rest of the pasture, this portion was entirely ungrazed. 
Usually the soil between the bunches of blue grama was bare and cracked during summer drought, and in only a few ranges was there the usual cover of litter. This, of course, was an after-drought effect from which the vegetation had not yet recovered.

Excellent examples were observed of ranges that had gone far toward recovery from drought but were having the annual yield removed too close to the soil. Except in ravines there were neither native forbs nor weeds, since all vegetation except the wavyleaved thistle (Cirsium undulatum) had been closely grazed (Fig. 39). Scarcely a single flower stalk of blue grama, which composed 85 percent of the grass, was found. The soil was, of course, barest on the hilltops. Here the basal cover often varied between 5 and 25 percent. Such close grazing is a dangerous prelude to deterioration or to desiccation. Grasslands that suffered most from drought were those formerly overgrazed. Just as desiccation affects vegetation first by decreasing the yield and then by reducing the basal cover, so too, close grazing is a first step in weakening underground parts, destroying seedlings, and inhibiting normal vegetative increase and the production of the necessary litter for protecting the soil (Weaver \& Darland 1947).

Several features of these ranges may be emphasized in contrasting them with similar ones in mixed prairie occurring 50 to 200 miles southward and extending from Nebraska to Central Kansas (Albertson \& Weaver 1942). A notable feature was the general thinning and opening of the cover of vegetation. Although this loess bluff area was not thoroughly studied in early drought, there is abundant evidence that while drought damage was great, it was not as serious as that in southern Nebraska and Kansas. Dusting was certainly far less, and recovery was somewhat more rapid, especially considering the small part played by buffalo grass in these steep loess hills. Under protection or moderate grazing the weed stages had disappeared.

The relatively few species of really abundant range grasses was a phenomenon eharacteristic of both

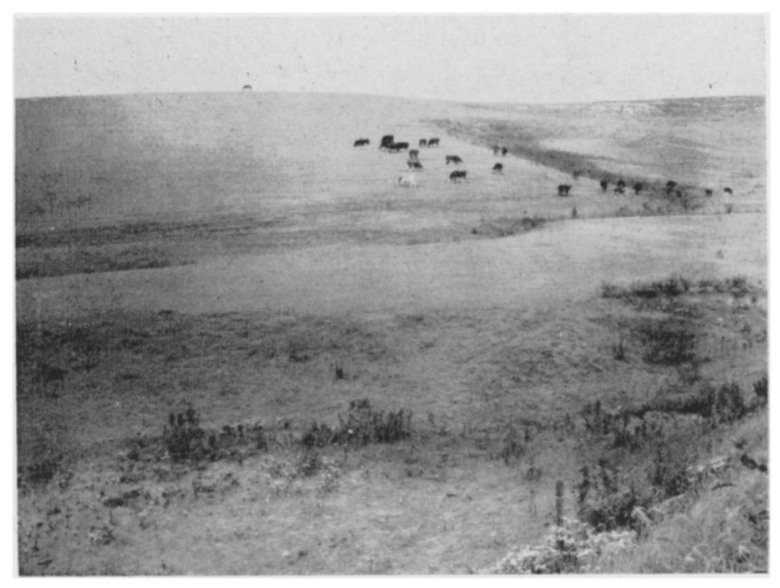

FIG. 39. Greatly overgrazed range near Ord. Almost the entire crop of forage had been harvested by the cattle and horses. The cover consists chiefly of blue grama. Photo July, 1943. areas. On uplands blue grama played the major role here; buffalo grass and blue grama were of nearly equal importance southward. In fact, except for sand dropseed, they were often the only perennial grasses (Weaver \& Albertson 1940). Because of the diversity of habitats, tall grasses (and especially big bluestem) were much more abundant here and the area dominated by postclimax species generally was much greater than that southward. Western wheat grass was also far more abundant.

Simplification of the structure of the veyetation had previously occurred as a result of long, continuous grazing. It resulted from the more or less complete removal of the mid-grass layer above the short grasses. Structure was further simplified by the almost complete removal by drought of many species of the ground layer and a wider spacing of the remaining ones. While forbs were still relatively few over the loess hills, species were far more abundant and numbers of individuals larger than southwestward. The number of species from true prairie was also much greater. All of these differences may be attributed to a combination of factors-topography, mellow and deep loess soils, and farther removal from the great central area of desiccation in the southwest.

\section{LAter Survey}

Under grazing, the tall and mid grasses are reduced in vigor much more rapidly than are the short grasses. This is largely due to the fact that more foliage is left on the shorter grasses when the range is closely grazed. Except on steep banks, the taller grasses occurred most abundantly on the level lowlands and lower slopes. Here these species, all of high palatability, were easily available to livestock and the impact of grazing was often heavy. The new growth of the bluestems and other plants was highly relished and they were soon regrazed. The livestock not only grazed in the bottoms of the ravines and in broad hay pockets often found in them, but also they were enticed by the lush forage to graze on the banks as well. Hence, even on the steep banks paths occurred which commonly ascended very gradually along the long axis of the slope. Indeed series of such parallel paths, 8 or 9 in number and one above the other, were common in older pastures where the banks of the ravines were high. By this means all of the forage on the entire slope had been reached. Even after the more or less level bottoms had degenerated into a vegetation of short grass, but not infrequently (in recent years) containing much bluegrass, the less accessible slopes often maintained much of their original cover. But in many ranges that had been heavily stocked, these banks, like the catsteps in other portions of the pasture, finally lost their tall and mid grasses because of grazing and trampling and became more or less completely clothed with blue grama, or with western wheat grass and buffalo grass (Fig. 40). The valley below was often clothed with short grass or western wheat grass except where enough eroded soil had been deposited to maintain a weedy subsere. 


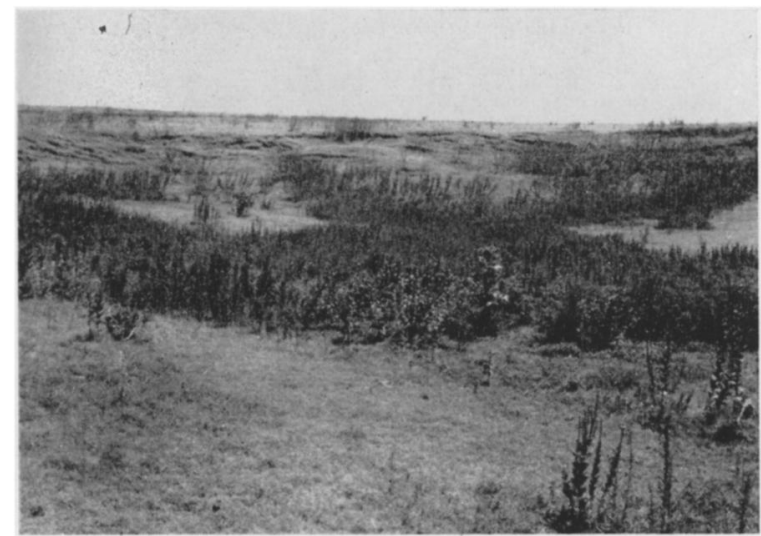

Fic. 40. View in an old buffalo grass pasture near Ravenna showing mats of buffalo grass on the rough banks of a ravine which have entirely replaced side-oats grama and other mid and tall grasses usually found in such places. Chief weeds are ironweed (Vernonia baldwinii) and hoary vervain (Verbena stricta).

On the lower slopes of hills and on the catsteps, wherever they occurred, the gradual degeneration of tall and mid grasses had been similar, although relicts often persisted a long time. Where mixed short and taller grasses grew, all but the short grasses were ultimately "grazed out."

A second area where grazing was usually heavy was on the more or less level hilltops and upper slopes. Consequently the grasses here were often less vigorous when drought eame and the losses were far greater than on midslopes where grazing had been less severe.

The general effects of drought on the range was to decrease the amount of buffalo grass much more than that of the more drought resistant blue grama. Where these two grasses occurred in mixture it was not uncommon for buffalo grass to entirely disappear from the ridges, which were then reclothed from the relict clumps of blue grama. In many pastures the blue grama had succeeded in covering only a fourth or a third of the soil of the ridges and steepest slopes. On other hilltops the interspaces had only begun to be filled with patches of buffalo grass.

Long continued heavy grazing of a mixture of short grasses was less harmful to the sod-forming buffalo grass than it was to the bunches of blue grama. Hence such ranges suffered great denudation during drought, but they also recovered more quickly after drought, the soil being rapidly reclaimed by stolons of relict plants and patches of plants of buffalo grass or by means of their seedlings. While many ranges had at least relict patches of big bluestem, side-oats grama, and little bluestem-since these taller grasses persisted a long time-in the main (except for western wheat grass) they were short grass pastures. This is revealed in Table 6 .

In Table 6 the general location of each of the 29 pastures is indicated only approximately by one of the nearest towns. The grazing intensity is that of the current year. This had nearly always been the same the preceding year. The basal area is the average of estimates over the portion of the range dominated by short grasses. This type nearly always occupied all but small portions of the range. Exceptions were areas of wheat grass, and rarely sand dropseed, on certain slopes with extensive catsteps. The percentage composition of the cover is that of the dominant species only; the small amounts of various other grasses and forbs were not considered. Annuals as little barley and hairy chess are discussed elsewhere.

Of the 29 pastures listed in Table 6, 9 were characterized by buffalo grass (with only 15 percent or less of blue grama) and 8 by blue grama (with buffalo grass 15 percent or less in abundance). But where larger percentages of the second ranking grass were present, buffalo grass exceeded blue grama in only 3 pastures, while blue grama exceeded buffalo grass in 7 . Grazing was light, moderate, or none in 18 of the pastures, 9 were overgrazed, and 2 were intermediate. The first 13 in the table were studied in 1943, and the remainder in 1946 and 1947. It should be emphasized that nearly all of the buffalo grass pastures were near the periphery of extensive grazing areas, where much of the land was farmed. The ranges were smaller and grazing nearly always more intense. This was also true in a large measure in all ranges where the percentage of buffalo grass exceeded that of blue grama.

A few facts about some of the grasses previously mentioned should be added, and the occurrence of other species pointed out. The distribution of western wheat grass was difficult to describe. It was of no importance in some pastures, in others it was scattered lightly nearly throughout; sometimes there were dense local patches only, but in still others there were extensive stands. Furthermore, while western wheat grass sometimes dominated almost to the exclusion of other grasses, more usually it formed an overstory to the short grasses; but it was also intermixed with side-oats grama, big bluestem, or sand dropseed, and less frequently with other species.

Side-oats grama, aside from western wheat grass, was probably the most widely distributed mid grass. In moderately grazed pastures it occurred thinly, or locally thickly, from hilltop to ravine bottom. When finally replaced by a dense sod of short grasses, relicts still occurred along the banks of ravines and on catsteps. Since the years of above-normal precipitation, some Kentucky bluegrass has been present in nearly every pasture. Always grazed closely, it was often found in small to extensive patches in the bottoms of ravines. Sometimes it had spread upward along ravines to hilltops, and it was also found with mid grasses on the catsteps.

The abundance of sand dropseed in the subsere during drought, where it not infrequently dominated in pure stands, has been mentioned. It was scattered here and there among other grasses but also occurred in abundance from the steepest hillerests to the denuded soil in eroding bottoms of ravines or on their banks. Bared or semibared areas, whether due to 
TABLE 6. General location, type, and grazing intensity of 29 representative pastures in the loess bluffs. Variation in the basal cover from the average of the more open to the average of the denser short-grass type is shown in percent. The estimated percentage composition provided by each of the dominants is included and the general condition in regard to weeds.

\begin{tabular}{|c|c|c|c|c|c|c|}
\hline Station & Type & $\begin{array}{c}\text { Grazing } \\
\text { intensity }\end{array}$ & $\begin{array}{c}\text { Basal cover, } \\
\text { percent }\end{array}$ & $\begin{array}{r}\text { Composition } \\
\text { grass cover, }\end{array}$ & $\begin{array}{l}\text { perennial } \\
\text { percent }\end{array}$ & Weeds \\
\hline $\begin{array}{l}\text { West of Ravenna . . . . . . } \\
\text { Northwest, Ravenna . . . } \\
\text { South of Loup City . . . . } \\
\text { West of Loup City . . . . } \\
\text { South of Broken Bow . . . }\end{array}$ & $\begin{array}{l}\text { Buffalo grass } \\
\text { Buffalo grass } \\
\text { Blue grama } \\
\text { Sand dropseed } \\
\text { Blue grama }\end{array}$ & $\begin{array}{l}\text { Moderate } \\
\text { Moderate } \\
\text { Light } \\
\text { Ungrazed } \\
\text { Moderate }\end{array}$ & $\begin{array}{l}80-98 \\
25-100 \\
50-60 \\
75-85 \\
35-40\end{array}$ & 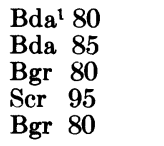 & $\begin{array}{lr}\text { Bgr } & 19 \\
\text { Bgr } & 13 \\
\text { Bda } & 5 \\
\text { Bgr } & 5 \\
\text { Asm } & 12\end{array}$ & $\begin{array}{l}\text { Few } \\
\text { Many } \\
\text { Few } \\
\text { Few } \\
\text { Few }\end{array}$ \\
\hline $\begin{array}{l}\text { Southeast, } \\
\quad \text { Broken Bow } \ldots \ldots \ldots \\
\text { East of Broken Bow } \ldots \ldots \\
\text { North of Broken Bow } \ldots \ldots \\
\text { East of } \\
\quad \text { Round Valley } \ldots \ldots \ldots \ldots \\
\text { West of Ord ............... }\end{array}$ & $\begin{array}{l}\text { Blue grama- } \\
\text { buffalo grass } \\
\text { Blue grama } \\
\text { Blue grama } \\
\text { Blue grama- } \\
\text { buffalo grass } \\
\text { Blue grama }\end{array}$ & $\begin{array}{l}\text { Overgrazed } \\
\text { Light } \\
\text { Light } \\
\text { Light } \\
\text { Overgrazed }\end{array}$ & $\begin{array}{c}5-8 \\
35-40 \\
\\
30-40 \\
\\
50-95 \\
40-50\end{array}$ & $\begin{array}{ll}\text { Bgr } & 95 \\
\text { Bgr } & 85 \\
& \\
\text { Bgr } & 90 \\
& \text { Bda } \\
\text { Bgr } & 60 \\
\text { Bgr } & 85\end{array}$ & $\begin{array}{ll}\text { Bda } & 5 \\
\text { Asm } & 8 \\
\text { Asm } & 5 \\
\text { Bda } & 35 \\
\text { Bda } & 15\end{array}$ & $\begin{array}{l}\text { Many } \\
\text { Few } \\
\text { Few } \\
\text { Few } \\
\text { Few }\end{array}$ \\
\hline 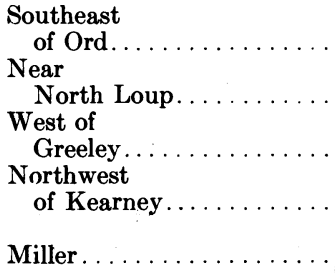 & $\begin{array}{l}\text { Wheat grass- } \\
\text { side-oats grama } \\
\text { Blue grama- } \\
\text { buffalo grass } \\
\text { Blue grama- } \\
\text { side-oats grama } \\
\text { Buffalo grass- } \\
\text { blue grama } \\
\text { Buffalo grass- } \\
\text { blue grama }\end{array}$ & $\begin{array}{l}\text { Ungrazed } \\
\text { Ungrazed } \\
\text { Overgrazed } \\
\text { Moderate } \\
\text { Moderate }\end{array}$ & $\begin{array}{r}40-60 \\
5-80 \\
80-85 \\
80-85\end{array}$ & $\begin{array}{l}\text { Asm Bcu } \\
\text { Bgr } 60 \\
\text { Bgr } 70 \\
\text { Bda } 75 \\
\text { Bda } 66\end{array}$ & $\begin{array}{l}\text { Afu } \\
\text { Bda } 20 \\
\text { Bcu } 25 \\
\text { Bgr } 25 \\
\text { Bgr } 33\end{array}$ & $\begin{array}{l}\text { Few } \\
\text { Few } \\
\text { Many } \\
\text { Many } \\
\text { Many }\end{array}$ \\
\hline 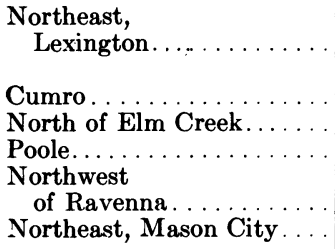 & $\begin{array}{l}\text { Blue grama- } \\
\text { buffalo grass } \\
\text { Blue grama } \\
\text { Buffalo grass } \\
\text { Buffalo grass } \\
\text { Blue grama- } \\
\text { buffalo grass } \\
\text { Blue grama }\end{array}$ & $\begin{array}{l}\text { Moderate } \\
\text { to close } \\
\text { Moderate } \\
\text { to close } \\
\text { Ungrazed } \\
\text { Moderate } \\
\\
\text { Overgrazed } \\
\text { Overgrazed }\end{array}$ & $\begin{array}{l}50-80 \\
30-75 \\
80-90 \\
80-90 \\
30-40 \\
40-80\end{array}$ & $\begin{array}{ll}\text { Bgr } 60 \\
\\
\text { Bgr } 85 \\
\text { Bda } 90 \\
\text { Bda } 90 \\
\text { Bgr } 60 \\
\text { Bgr } 60\end{array}$ & $\begin{array}{lr}\text { Bda } & 40 \\
& \\
\text { Bda } & 15 \\
\text { Bgr } & 10 \\
\text { Bgr } & 1 \\
& \\
\text { Bda } & 40 \\
\text { Bda } & 40\end{array}$ & $\begin{array}{l}\text { Few } \\
\text { Many } \\
\text { Many } \\
\text { Many } \\
\text { Many } \\
\text { Few }\end{array}$ \\
\hline 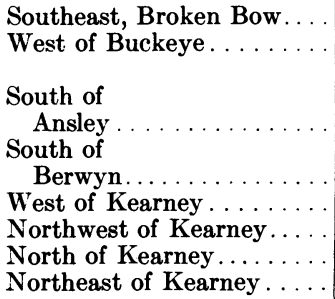 & $\begin{array}{l}\text { Buffalo grass } \\
\text { Blue grama } \\
\\
\text { Blue grama- } \\
\text { buffalo grass } \\
\text { Blue grama- } \\
\text { buffalo grass } \\
\text { Buffalo gras; } \\
\text { Buffalo grass } \\
\text { Buffalo grass } \\
\text { Buffalo grass }\end{array}$ & $\begin{array}{l}\text { Overgrazed } \\
\text { Moderate } \\
\text { Moderate } \\
\text { Moderate } \\
\text { Overgrazed } \\
\text { Moderate } \\
\text { Overgrazed } \\
\text { Overgrazed }\end{array}$ & $\begin{array}{l}60-90 \\
60-70 \\
75-80 \\
70-80 \\
50-70 \\
60-70\end{array}$ & $\begin{array}{l}\text { Bda } 85 \\
\text { Bgr } 95 \text { Bda } \\
\text { Bda } 0-80 \text { (fla } \\
\text { Bgr } 50 \\
\text { Bgr most wid } \\
\text { Bgr } 50-95 \\
\text { Bda } 80 \\
\text { Bda } 93 \\
\text { Bda } 93 \\
\text { Bda } 80\end{array}$ & $\begin{array}{ll}\text { Bgr } 10 \\
\text { (slopes) } \\
\text { t uplands) } \\
\text { Bda } & 50 \\
\text { espread } \\
\text { Bda } & 20-50 \\
\text { Bgr } & 10 \\
\text { Bgr } & 1 \\
\text { Bgr } & 5 \\
\text { Bgr } & 15\end{array}$ & $\begin{array}{l}\text { Many } \\
\text { Few } \\
\text { Few } \\
\text { Many } \\
\text { Few } \\
\text { Few } \\
\text { Many } \\
\text { Many }\end{array}$ \\
\hline
\end{tabular}

${ }^{1}$ Bda is Buchloe dactyloides; Bgr, Bouteloua gracilis; Scr, Sporobolus cryptandrus; Asm, Agropyron smithii; Bcu, Bouteloua curtipondulv; and Afu, Andropjzon furcatus.

erosion or deposit, trampling or drought, provided a suitable habitat for this species which thrives best in warm dry soils. It is not a good competitor and is easily replaced even by short grasses where they form a continuous sod. Tumblegrass is of quite similar distribution. It grows among the other grasses where the cover is thin and is sometimes the most abundant species locally in such habitats.

Plains muhly was not uncommon in ranges but was rarely found in great abundance. Penn sedge increased greatly during drought and, like involuteleaved sedge, occurred frequently and sometimes abundantly. Needle grass and needle-and-thread occurred only rarely and were never found in abun- dance. The bunch-forming hairy grama was found on dry banks and on other sites usually where the cover was open. June grass and Scribner's panic grass occurred somewhat sporadically and usually formed only a modicum of the vegetation. Species of three-awn grasses, nearly exterminated by the drought, were found only in certain parts of this great range area. They are almost worthless as forage. One was not impressed so much by the relatively small number of kinds of perennial grasses as by the extensive dominance of only a few.

WEEDY ANNUAL GRASSES

Certain weedy annual grasses were very abundant in many ranges and in spring they supplied much 
forage. The three most widely distributed and of greatest abundance were little barley, six-weeks fescue, and hairy chess. Little barley germinates in fall or very early spring and becomes green and edible before much new foliage of the short grasses appears. This diminutive grass often grew thickly in the short-grass mats, especially in older and closely grazed ranges or portions of ranges (Fig. 41). It occurred regularly even where the basal cover was very high, 80-95 percent. In open ground or in dunged places the usual height of its slender unbranched stems often doubled or tripled and reached a level of 12-16 inches. In spring, little barley alone or intermixed with the short grasses provided fairly good forage. But normally early in June and for many weeks thereafter dense yellowish patches or continuous stands of dried plants in the short grass cover gave tone to the landscape, just as the early greening of pastures was due to this species. Little barley is a native of mixed prairie and a normal component of the short-grass cover. In badly depleted ranges during drought, this weedy annual alone sometimes produced a ton or more of forage per acre (Weaver \& Albertson 1943). It was much less abundant some years after the drought and in many pastures it occurred, if at all, in insignificant amounts.

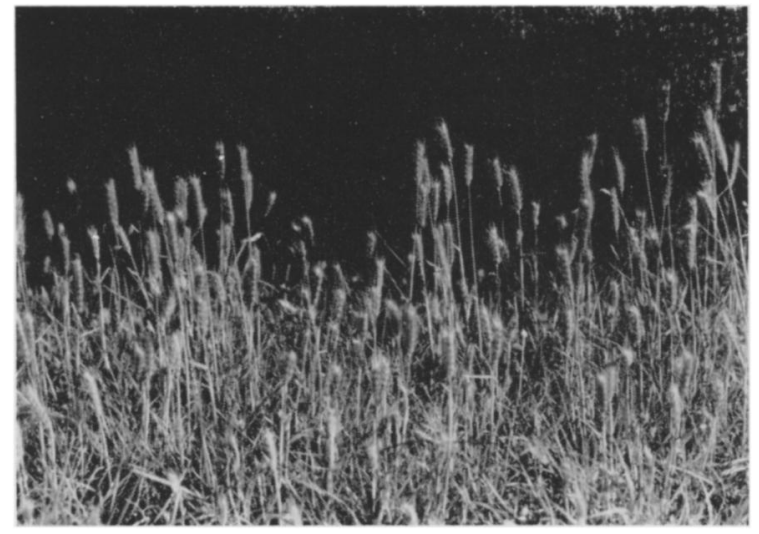

FIG. 41. Detail of little barley (Hordeum pusillum) growing in the sod of buffalo grass in the McCan experimental pasture near Kearney. Photo June 18, 1947.

The shorter and more spreading variety of sixweeks fescue (Festuca octoflora hirtella), has habits of growth very similar to those of little barley. The densely aggregated stalks of this annual frequently clothed the bare places, whether small or large, that occurred between the tufts of short grass. On hillsides and ridges where it was sometimes still found abundantly it gave the range a tinge of brownish yellow even when the short grasses remained green. This grass decreased with increasing density of the short-grass cover, and in 1947 it was found abundantly only in poorer pastures. Its forage value was low.

Hairy chess was common in nearly all ranges except where it had been grazed out in spring. In depleted lowland areas it often formed a continuous cover or an overstory to other grasses in spring, and attained a height of 1.5 to 2 feet. It also occurred, sometimes abundantly, with western wheat grass and with open stands of mid and tall grasses as well. It was most conspicuous in short-grass ranges, since the plants, which dry and bleach to a light gray in midsummer, often remained standing until fall, quite above the short grasses. This species of brome, which came in and spread widely during drought, has a high forage value in spring and early summer and the new young plants are eaten in fall.

\section{NATIVE FORBS}

Prairie plants other than grasses constitute a long list of species. Practically all are perennials, the annuals and biennials together composing only a small percentage. Many forbs decrease or mav entirely disappear under long continued grazing. But ordinarily they are sufficiently abundant to provide a valuable variety in the diet of livestock grazing native ranges, and they deserve careful consideration. Drought destroyed many of the forbs on the loess bluffs just as it affected them adversely elsewhere (Weaver \& Albertson 1940a, 1944). Many species almost entirely disappeared, others were greatly reduced in numbers and vigor. But during the several good years that have occurred since the drought the forbs have made considerable recovery. A survey was made of the forbs in 27 widely distributed pastures, which varied in size from 80 to several hundred acres; species have been listed for a group of 17 pastures according to the number in which they occurred. In another group of 10 pastures they have been listed according to their abundance. The lists might have been enlarged considerably if species in local habitats as ravines, banks, and other places especially favored in their water relations had been included. Species listed are those distributed more or less throughout the cover. Annual native forbs and introduced weeds are not included (Table 7).

Of the 29 species listed in 1943 (column A) only one occurred in all of the 12 pastures, but 15 were found in at least half of them. Species of eacti were found in only 5 pastures and they were never abundant. In fact, no forbs occurred in unusual numbers. Drought had taken its toll and recovery was just getting under way.

One of the most abundant species, the cone flower (Ratibida columnaris), almost disappeared during drought but had increased rapidly from seed, by which means it survived during the dry years. This was true also of western ragweed (Ambrosia psilostachya) except that its rhizomes aided in survival (Weaver: \& Albertson 1944). The list includes many of the 10 most drought resistant species of the central area of the mixed prairie which survived when practically all others had succumbed. The lead-plant, which has increased far beyond its normal numbers in mixed prairie, is so highly relished by livestock that it was found under grazing only as scattered relicts. In pastures generally, there are always fewer species and smaller numbers of native forbs (except- 
TABLE 7. Species of prairie forbs found most frequently in pastures. Of 12 representative ranges, numbers in column $A$ indicate in how many each species occurred in 1943. Column B is the number of pastures in another group of 5 in which these forbs occurred in 1947. Columns 1 to 10 , respectively, are the ratings for 10 other widely distributed ranges. The abundance of each species in a pasture is indicated according to a ranking on a 5-point scale ( 1 , very abundant; 2 , abundant; 3 , common; 4 , infrequent; and 5 , rare).

\begin{tabular}{|c|c|c|c|c|c|c|c|c|c|c|c|c|}
\hline Native Forbs & $A$ & B & 1 & 2 & 3 & 4 & 5 & 6 & 7 & 8 & 9 & 10 \\
\hline Ratibida columnaris .... & 12 & 4 & 3 & 3 & 2 & 3 & 4 & 4 & 4 & 4 & 3 & 4 \\
\hline Solidago mollis......... & 11 & 4 & 3 & 2 & 2 & 2 & 3 & . & 3 & 3 & 5 & 4 \\
\hline Kuhnia glutinosa........ & 10 & 4 & 3 & 3 & 4 & 4 & .. & 4 & 4 & 4 & 4 & 4 \\
\hline Liatris punctata........ & 10 & 5 & 2 & 3 & 4 & 3 & 3 & 3 & 4 & 4 & 2 & 2 \\
\hline Lygodesmia juncea..... & 10 & 5 & 3 & 2 & 3 & 3 & . & 3 & 4 & 3 & 4 & 3 \\
\hline Solidago glaberrima..... & 9 & 4 & 4 & 4 & 5 & 5 & 4 & . & 4 & 4 & 5 & 4 \\
\hline Ambrosia psilostachya... & 8 & 5 & 3 & 1 & 3 & . & 3 & . & .. & .. & 2 & 4 \\
\hline Sideranthus spinulosus. . & 8 & 4 & 2 & 3 & 1 & 2 & 3 & . & 3 & 4 & 3 & 4 \\
\hline Amor pha canescens.... & 7 & 3 & . & 5 & 5 & 4 & 4 & . & . & 3 & . & 4 \\
\hline Aster multiflorus......... & 7 & 3 & 4 & 4 & 5 & 5 & 4 & 4 & 4 & 4 & 5 & 5 \\
\hline Lithospermum linearifolium. & 7 & 3 & 3 & 4 & 4 & 5 & 5 & . & 4 & 4 & 5 & 2 \\
\hline Malvastrum coccineum..... & 7 & 4 & 3 & 3 & 1 & 1 & 2 & .. & 1 & 1 & 3 & 1 \\
\hline Artemisia gnaphalodes.... & 6 & .. & 2 & 4 & 3 & 3 & 2 & 3 & 4 & 4 & 4 & 4 \\
\hline Cirsium undulatum...... & 6 & 5 & 1 & 4 & 2 & . & 3 & 3 & 3 & 3 & 4 & 3 \\
\hline Cathartolinum rigidum... & 6 & 4 & 4 & 4 & 3 & 3 & 3 & 4 & 3 & 4 & 5 & 2 \\
\hline Allionia linearis......... & 5 & 3 & 4 & 5 & 5 & . & .. & .. & 5 & . & 5 & 4 \\
\hline Gaura coccinea......... & 5 & 5 & 3 & 3 & 3 & 4 & 4 & 4 & 4 & . & 2 & 3 \\
\hline Opuntia species........... & 5 & 4 & .. & .. & . & . & 4 & . & 3 & 5 & . & 3 \\
\hline Petalostemum purpureum.... & 5 & 2 & 4 & 4 & 4 & 3 & 3 & .. & 4 & 5 & 4 & 4 \\
\hline Vernonia baldwinii...... & 5 & 5 & 1 & 3 & .. & .. & 4 & .. & 3 & 4 & 5 & 4 \\
\hline Antennaria campestris... & 4 & 1 & . & .. & 5 & .. & 5 & $\ldots$ & 5 & 5 & .. & 5 \\
\hline Echinacea pallida...... & 4 & 3 & 3 & 4 & 4 & 4 & 4 & 3 & 4 & 4 & 5 & 4 \\
\hline Psoralea tenuiflora... & 4 & 4 & .. & . & .. & .. & 1 & 1 & 1 & 2 & . & 1 \\
\hline Psoralea argophylla... & 3 & 4 & 3 & 5 & 5 & . & 5 & 4 & 3 & .. & $\cdots$ & 3 \\
\hline Meriolix serrulata... & 3 & 2 & . & . & $\because$ & . & 4 & 4 & .. & .. & $\cdot$ & 5 \\
\hline Aster oblongifolius.... & 2 & 2 & . & 5 & 5 & . & .. & 5 & .. & .. & & 4 \\
\hline Callirhoe involucrata..... & 2 & 3 & 4 & 5 & .. & .. & . & .. & .. & . & 5 & 2 \\
\hline Cathartolinum sulcatum.... & 2 & 1 & 4 & 5 & .. & 3 & 4 & .. & 4 & $\mathbf{5}$ & . & .. \\
\hline Rosa pratincola.............. & 2 & 1 & 5 & . & 5 & 3 & 4 & 3 & 4 & 5 & .. & 4 \\
\hline
\end{tabular}

ing a few that become weeds) than in prairie. Moreover, as a rule, great decrease in amount of forbs indicated prolonged and severe grazing.

Cactus was abundant in only a very few pastures in 1946-1947 and entirely absent from many. Like the cactus, several of the forbs listed have little or no forage value. These include Cirsium undulatum, which is spiny, Lygodesmia juncea, Ambrosia psilostachya, Sideranthus spinulosus, and Vernonia baldwinii. The last shows a decided tendency to increase in low ground. The only shrub of considerable range in pastures was buckbrush. It sometimes maintained itself in low thickets along ravines and recurred on hillsides where there was an adequate supply of water. However, it was not usually a serious weed.

Other perennial forbs found in several ranges included Geoprumnon plattense, Astragalus lotiflorus, Asclepias pumila, Cirsium ochrocentrum, Solidago rigida, Pentstemon albidus, and Petalostemum candidum. In fact, relicts of nearly all of the prairie forbs were seen in various ranges.

Native annual forbs of greatest local abundance were Plantago purshii and Hedeoma hispida. Euphorbia marginata Pursh was conspicuous where abundant on low ground in late summer and fall.

The chief introduced weeds were hoary vervain
(Verbena stricta), prostrate vervain ( $V$. bracteosa), and especially horseweed (Figs. 42 and 43). The first is an indicator of a broken cover and, if abundantly and widely distributed, it indicates pasture abuse. The low growing verbena properly belongs to the subsere and it is found only where a good plant cover has not been maintained. Horseweed varied greatly in amount from year to year. When weather in spring was favorable for its germination and establishment it occurred throughout most ranges in stands of variable density. Where the cover of grasses was good and competition for water great, the plants were usually dwarfed to 8-12 inches in height, but in more open cover a stature of 2 to 3 feet was often attained. When young, this weed was consumed with the grasses, and where grazing was frequently repeated there were few of them. But elsewhere, once they were half developed they were not eaten and grew in stands so thick as greatly to hinder later grazing. In good years they were so abundant and so. widely distributed as to give the ranges a green tinge even during periods when the grasses were drying.

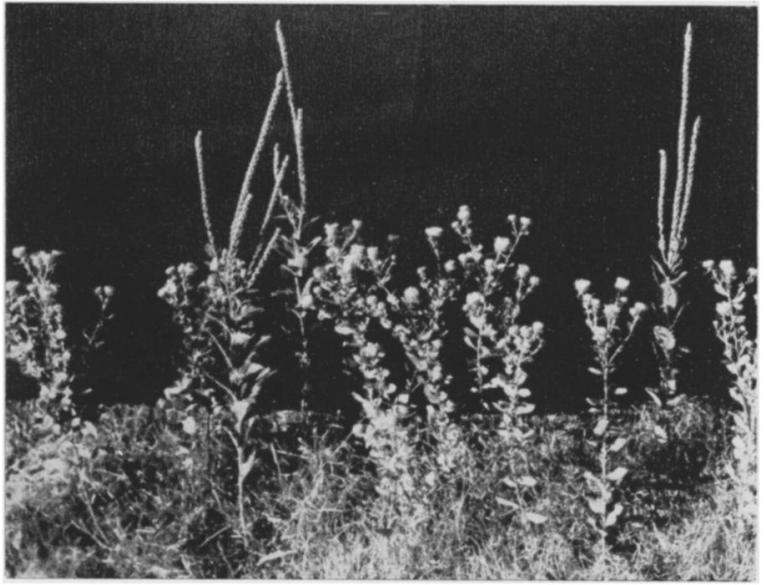

Fig. 42. Gumweed (Grindelia squarrosa) and hoary vervain in an old pasture. The vervain has a much more general distribution than the gumweed.

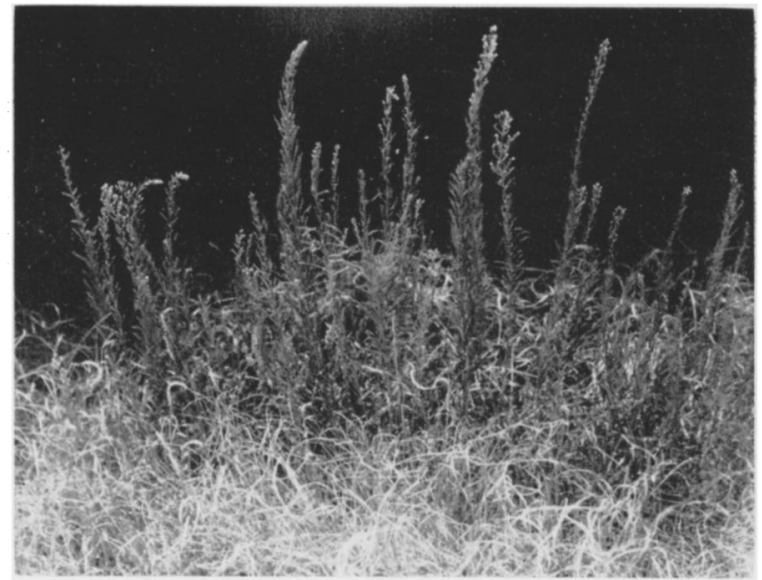

Fra. 43. Horseweed (Leptilon canadense). This is the most widely distributed and abundant of the larger, annual weedy forbs in the pastures of the loess bluff region. 


\section{SUBSERES}

Some low-grade pastures have resulted from abandoning cultivated land. These were usually on such steep slopes that the land should never have been broken. For many years annual and perennial weeds constituted the bulk of the scanty cover of vegetation. Perennial grasses enter and increase slowly (Fig. 44). A single example must suffice.

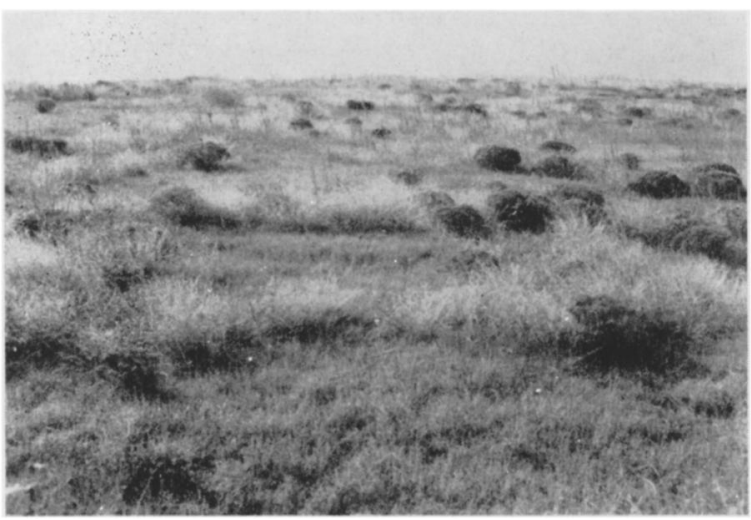

FIG. 44. A steep hillside where the prairie had been broken about 25-30 years earlier. The succession has now reached the red three-awn-buffalo grass stage. The rounded bushes are the perennial brownweed (Gutierrezia sarothrae). Many prairie forbs are present; sand dropseed (Sporobolus cryptandrus) and tumblegrass (Sche donnardus paniculatus) are common, but there is no blue grama.

A 23-year-old subsere was studied in the Sheen pasture (Fig. 45). Development toward the climax vegetation was far more advanced on the level land with Holdrege silt loam. Only 2 out of 20 of the 100 -square-foot sampling plots had a foliage cover less than 50 percent and in most the cover was 70 to 85 percent. Sand dropseed was the most abundant grass in about two-thirds of the areas sampled, and supplied 58 percent of the cover. Buffalo grass ranked first in only one-fifth. Other important grasses were western wheat grass and hairy chess.

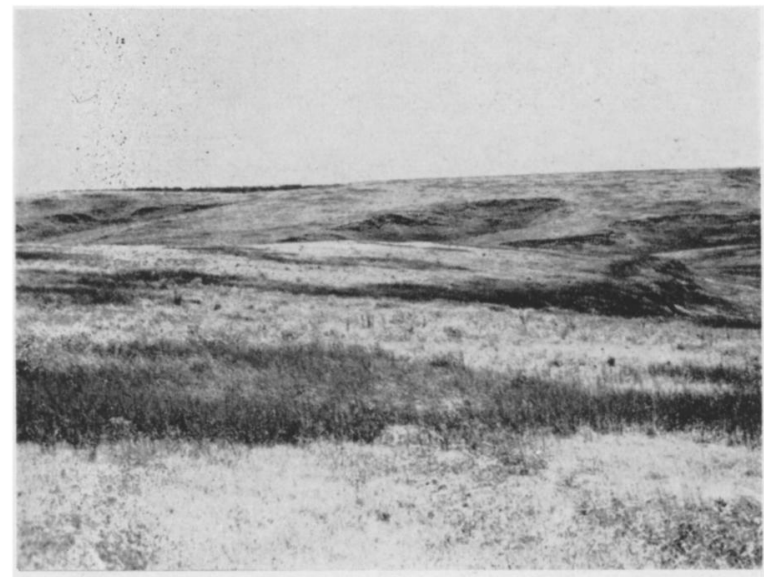

Fig. 45. View of western wheat grass (5 dark streaks in foreground) alternating with purple three-awn (Aristida purpurea) and buffalo grass (light colored). Portion of 23-year-old subsere in the Sheen experimental pasture. Photo June 18, 1947.
Little barley, three-awn grasses, and tumblegrass were common and widely distributed. Chief weedy forbs were hoary vervain, prostrate vervain, and a spurge (Chamaesyce glyptosperma).

On the slopes on the Colby silt loam soil the vegetation was much thinner. Here the foliage cover ranged from 30 to 45 percent in 9 plots, 50 to 55 in 26 , and 60 to 65 in only 13 . Only 4 of the 52 plots had a good cover, 70-80 percent. Three-awn grasses (annual and perennial) provided two-thirds of the cover in a third of the plots. Sand dropseed was sceond in abundance and quite as widely distributed. Western wheat grass and buffalo grass were next in importance. Where the topsoil had washed away, native perennial plants had great difficulty in becoming established. The scarcity of legumes in the subsere was marked.

Some success has been attained by disking low grade pastures in early spring, thus leaving the established patches of buffalo grass, and seeding to blue grama with seed of buffalo grass and side-oats grama intermixed. But much success was obtained only in good years and failures were common, since the unfavorable conditions included the lack of a sufficient dead mulch, in addition to drought and erosion. When warm-season grasses as big bluestem, little bluestem, and side-oats grama were seeded in spring following a crop of smallgrain, Sudan grass, or sweet clover, better results were obtained. This was partly due to an increased supply of nitrogen and in part to a protective dead mulch. The very drought- and cold-resistant crested wheat grass may do well if seeded late in fall so as to escape damage from grasshoppers. Like Hungarian bromegrass, it should be drilled on the contour. Usually bromegrass does less well on the hills than crested wheat grass, but good stands are fairly certain in the valleys. Despite the great difficulties of reestablishing a permanent cover, the need for such a cover is so great that extraordinary efforts should be made to reclaim abandoned fields and to restore a complete cover on depleted ranges. The need is almost desperate; the price of neglect is the loss of the soil and the disturbance or destruction of the plant cover where the eroded soil is deposited. Erosion on these bluffs is so prevalent that almost every rancher and farmer is well aware of this danger.

\section{EXPERIMENTAL PASTURES}

Two pastures were selected for a study of the monthly and annual yield and consumption of forage in the several pasture types. In addition careful account was made of the manner and places of grazing during 1945-47, inclusive. The pastures were selected near Kearney because of their convenience for study, since the second author was in residence at that eity. In the Sheen pasture consumption of forage alone was ascertained the first year, and both yield and consumption the second. Because of the great reduction in the size of the herd, study was not continued in 1947. But in the McCan pasture both yield and consumption of forage were ascertained during each of three years. 


\section{Methods}

The methods were the same as those used by Weaver and Darland (1948) in their 4-year study of native pastures near Lincoln, Nebraska. Several sampling areas of about 10 square rods each were selected in each of the several grazing types. In each sampling area, one 30-square-foot exclosure, with its grazed control of similar size, was located in early spring. It was moved to a new location in this area at the end of each of the months of the grazing season.

In selecting the original location for an exclosure, two places were chosen within 10 to 15 feet of each other in which the vegetation was as nearly alike as possible. In one, the vegetation was to be clipped after a month of protection; the other, which was subjected to grazing, was also to be clipped at the same time. A coin was tossed to determine which of the two areas was to be protected. The exclosure was then set in place and stakes were driven into the soil in each corner to keep it from being pushed aside. Since the sides of the exclosure sloped inward from the base, it was not disturbed by the livestock. The control area was also clearly marked. At the end of each month at the time of the clipping, new places for the exclosure and control were selected in the same general area. These were as nearly as possible like the former control area and were selected before elipping, since both of the former plots were now to be clipped by hand close to the ground, closer than the cattle could graze. By subtracting the dry weight of vegetation of the control from that obtained from the exclosure, the monthly consumption from the 30-square-foot area was obtained (Fig. 46) (Fuelleman \& Burlison 1939; Joint Committee 1943).

It was assumed that the average yield in any type during the first month was represented by the airdry forage under that exclosure, since all debris from the previous year was carefully separated from the new vegetation and discarded. During the second month total yield was the amount that grew on the area newly exclosed lcss the amount of new vegeta-

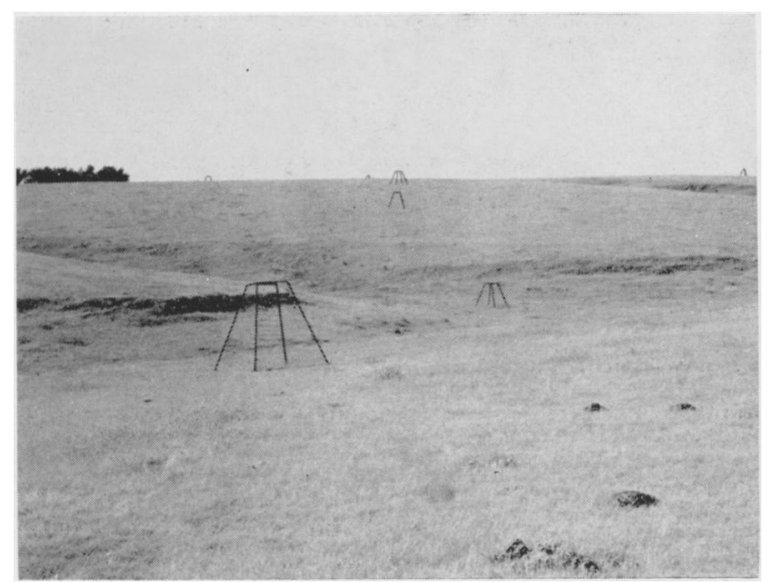

Fig. 46. View in the northern part of the MeCan experimental pasture showing several of the movable exclosures used in determining consumption and yield. The area under each is 30 square feet. tion remaining ungrazed in the control area of the preceding month. Clipping was uniform at all times, since one of the writers was in direct charge each month (Klingman, Miles, \& Mott 1943). An example of the results in 1946 from an exclosure and control in buffalo grass in the McCan pasture is shown in Table 8 . The average monthly consumption and yield as determined by the several exclosures are shown in graphs.

TABLE 8. Amount of new forage harvested from an exclosure on a nearly level hilltop and from its control each month in 1946. The air-dry weights are in grams.

\begin{tabular}{|c|c|c|c|c|c|c|}
\hline & May & June & July & August & Sept. & October \\
\hline $\begin{array}{l}\text { Exclosure.. } \\
\text { Control... }\end{array}$ & $\begin{array}{l}389.0 \\
307.5\end{array}$ & $\begin{array}{l}373.8 \\
246.3\end{array}$ & $\begin{array}{l}342.8 \\
193.3\end{array}$ & $\begin{array}{l}275.3 \\
231.3\end{array}$ & $\begin{array}{l}259.7 \\
231.7\end{array}$ & $\begin{array}{l}233.7 \\
202.0\end{array}$ \\
\hline Amt. consumed & 72.5 & 127.5 & 149.5 & 44.0 & 28.0 & 31.7 \\
\hline \multirow{2}{*}{$\begin{array}{l}\text { Exclosure } \ldots . . . \\
\text { Control of pre- } \\
\text { ceding month }\end{array}$} & 380.0 & 373.8 & 342.8 & 275.3 & 259.7 & 233.7 \\
\hline & 0.0 & 307.5 & 246.3 & 193.3 & 231.3 & 231.7 \\
\hline Amt. of yield... & 380.0 & 66.3 & 96.5 & 82.0 & 28.4 & 2.0 \\
\hline
\end{tabular}

\section{Sheen Pasture}

This pasture was on typical loess bluffs 4.5 miles west of the city of Kearney and $1 / 2$ mile north of the Kearney canal, which here is at the foot of the bluff region on the edge of the Platte River Valley. The hills are about 120 feet higher than the lowest ravines (Fig. 47). The general elevation is about 2,300 feet. The pasture consists of 160 acres of rolling, much dissected land, characteristic of the region. The slope varies in steepness from 8 to 21 percent, but some slopes below the high banks of ravines, still clothed with vegetation, are as steep as 68 percent. The soil is Colby silt loam, except about 25 acrcs of nearly level land on the west end of the pasture which is Holdrege silt loam. About 80 acres of the west part of the pasture was broken in 1925. The pasture is surrounded on all sides except the south by extensive areas of range land.

\section{GRAZING TYPES}

Vegetation in the pasture was not uniform but consisted of four communit:es or types. The buffalo grass type occurred on land with rolling topog-

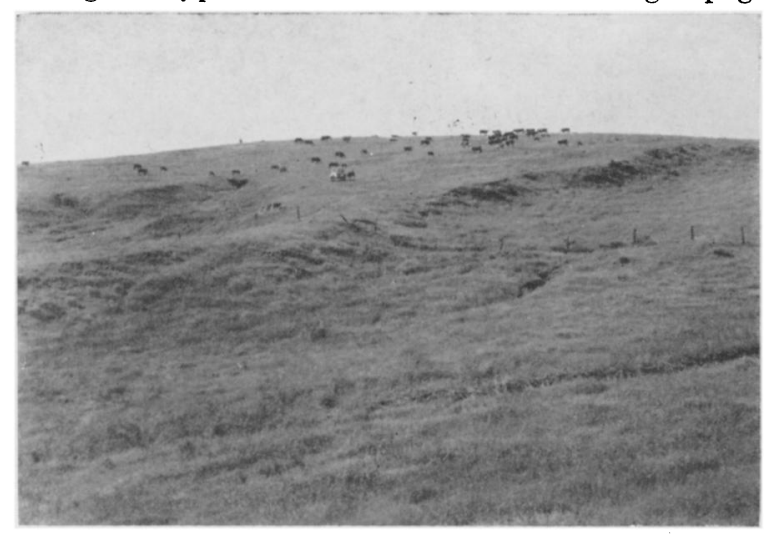

Fig. 47. View in the Sheen pasture showing the rough topography. Photo June 22, 1945. 
raphy. This included rounded hilltops and gentle to steep slopes which ended abruptly on their lower sides at the steep banks bordering the eroded valleys (Fig. 48). Here a fringe of side-oats grama, western wheat grass, and other taller grasses was found.

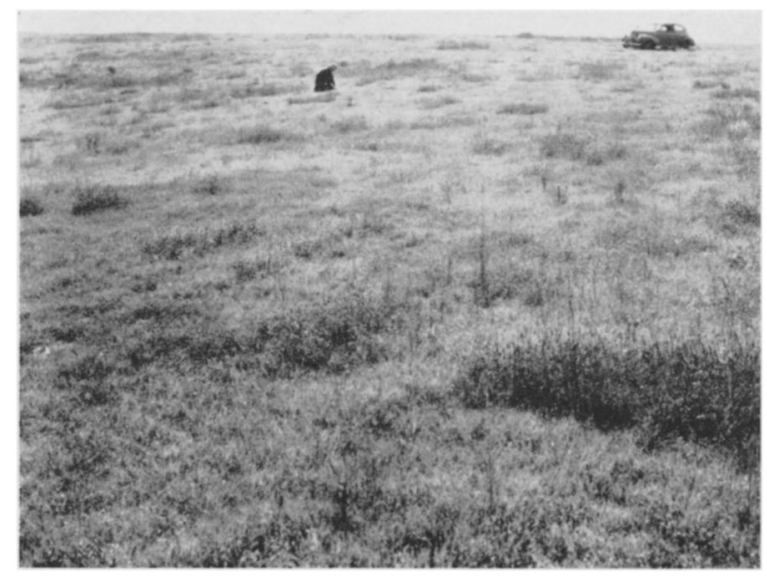

FIg. 48. Typical view on a long slope of about 10 percent in the buffalo grass type. Irregularities in the cover are due to clumps of little barley especially well developed in spots that have been fertilized. Photo June 22, 1947.

This pasture type was one of the most extensive and supplied by far the largest part of the season's forage. There was very little blue grama anywhere, seldom over 5 percent, but little barley grew thickly even in the dense short-grass sod. Small amounts of western wheat grass were common. The average basal cover was about 85 percent.

The sand dropseed-buffalo grass type covered most of the flat upland where grazing throughout many years had been most severe. Consequently it was most damaged by the prolonged drought (Weaver $\&$ Albertson 1940). It was undoubtedly at one time in the buffalo grass stage of degeneration of mixed prairie. Because of less runoff, this was probably a more productive type than the present one dominated by sand dropseed. In this community the sand dropseed formed a more or less continuous cover (Fig. 49). But in it were relict, often circular patches of buffalo grass. These had increased regularly but slowly in size since the close of the great drought and with newly established patches now occupied a fourth to a third of the soil surface. But the sod was more open than that on the hillsides. The discontinuous patches varied from a few feet to several yards in diameter, and the increase in size was at the expense of sand dropseed. There was, in general, much more open ground here than in the preceding type. Hence such forbs as western ragweed, hoary vervain, red false mallow (Malvastrum coccineum), and others occurred in greater abundance as did also several species that were not found regularly in the closed cover. Here little barley was better developed than in the buffalo grass sod and tumblegrass was more plentiful.

On the level 25 acres of the part of the pasture

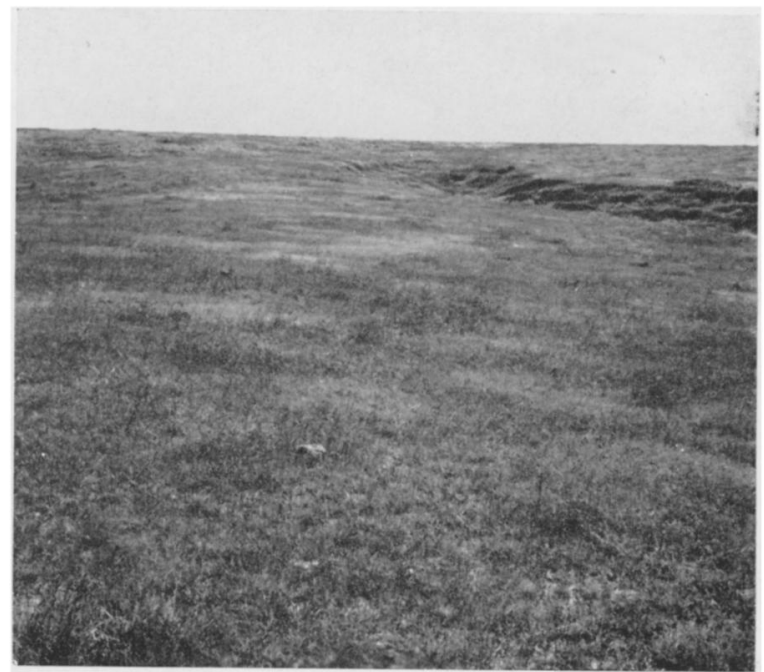

Fig. 49. General view in the sand dropseed-buffalo grass type. The light colored places are small patehes of buffalo grass. In the darker places the rather open cover is mostly sand dropseed.

once broken, the sand dropseed-buffalo grass type had developed as a distinct successional stage. Except that it was much weedier than this type on the unbroken land, the two were almost identical. Basal cover throughout the sand dropseed-buffalo grass type averaged about 70 percent. With few exceptions blue grama occurred only in small amounts and most abundantly in rough places where it had survived the drought.

A third community, the buffalo grass-bluegrass type of lowlands, received runoff water in addition to the precipitation. Moreover, snow is blown from the hills into the valleys or is lodged on the slopes and in melting adds moisture to these lowlands. This additional soil moisture was reflected not only by the presence of Kentucky bluegrass, many coarse sedges, and various species of mesic grasses, but also by the rank growth of the vegetation in early spring. The presence of buckbrush and certain other shrubs, often in considerable abundance, was further evidence of the more favorable supply of soil moisture (Fig. 50).

Although the most abundant species was buffalo grass, bluegrass was also found abundantly. Locally it occurred in nearly pure stands in the most mesic sites, but it was often intermixed with buffalo grass on these lowlands. It was the most abundant grass and often the only one growing in the thickets of buckbrush. Eventually this species was sought out, even here, and closely grazed. On the valley floor there also occurred relict plants of big bluestem, penn sedge, and Scribner's and Wilcox's panic grasses. Here also sidc-oats grama was found but more plentifully, as was also big bluestem, on the slopes. Only a trace of little bluestem remained but numerous prairie forbs occurred as relicts on the rough banks. Western wheat grass, as in the other types, occurred in small widely scattered patches. It was here that hairy chess reached its greatest density 


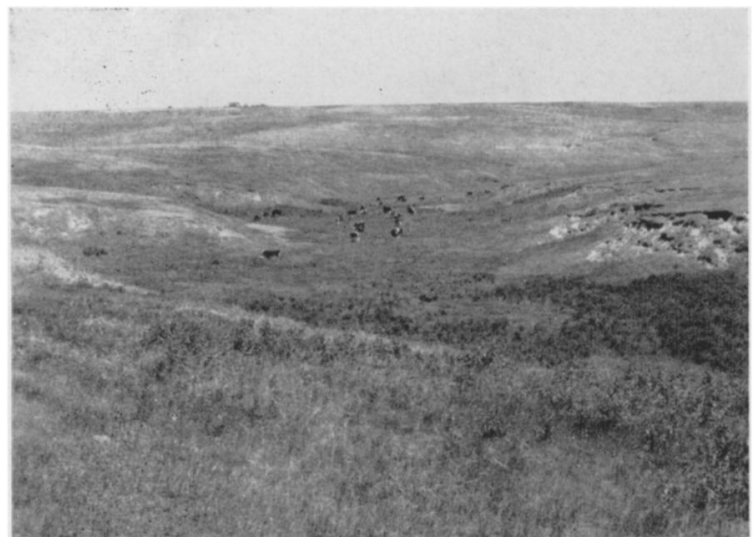

Fig. 50. Cattle grazing in the buffalo grass-bluegrass type in one of the several valleys in this pasture. This is a side canyon near the windmill and it has been grazed closely. Note the buckbrush in the valley and on the steep bank in the foreground.

of stand and greatest stature. In early spring it overtopped all the other grasses and provided much palatable forage during a period of about six weeks. Ordinarily it is not all eaten, but remains in patches or as an open network of dried, unpalatable forage which greatly hinders uniform grazing thereafter. An average basal cover of 82 percent was ascertained in this type.

The three-awn grass type covered all of the slopes on the west 80 acres except a small percentage consisting of steep banks that were left unplowed. Chief perennial grass was purple three-awn. Its bunches, however, were so widely spaced that they alone did not form a complete cover. Intermixed with them in large amounts was the annual, prairie three-awn (Aristida oligantha). This short-lived grass produced so much of the foliage cover that alive or dead it played a remarkable role in protecting the soil from erusion. Neither of these subsere grasses was grazed in any amount, if at all. Of valuable range grasses, the order of abundance was sand dropseed, buffalo grass, western wheat grass, and small amounts of side-oats grama. Sand dropseed was rather generally distributed throughout. Buffalo grass occurred only in widely spaced, small patches and did much toward stabilizing the soil which erosion had reduced to such low fertility that the grass was only half as tall here as on the level land that had maintained its topsoil. Western wheat grass occurred in streaks and patches and was widely distributed in locally open stands (Figs. 51 and 52). It was often dwarfed. The soil beneath it was usually bare. In addition there were small amounts of blue grama as isolated clumps and also tumblegrass. There was much erosion of the light colored, flour-like loess around the bunches. Many of the bunches of blue grama were elevated 5 to 6 inches above the present soil surface.

Although some prairie forbs and especially $A s$ tragalus shortianus and Malvastrum coccineum were common to abundant, in some places on the thinnest soil there were few perennials. Here there was a thin cover of hairy chess and little barley. Fre-

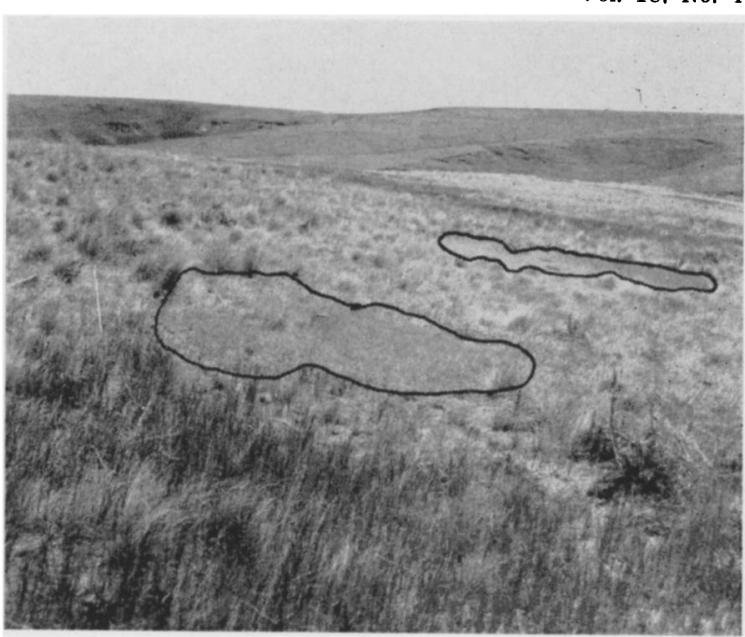

Fig. 51. View in tnree-awn grass type on a steep hillside. The encircled patches are buffalo grass, the dark one in the foreground and another in the distance are western wheat grass, but the most extensive vegetation is three-awn grass. Bunches of purple three-awn show plainly at the left beyond the western wheat grass.

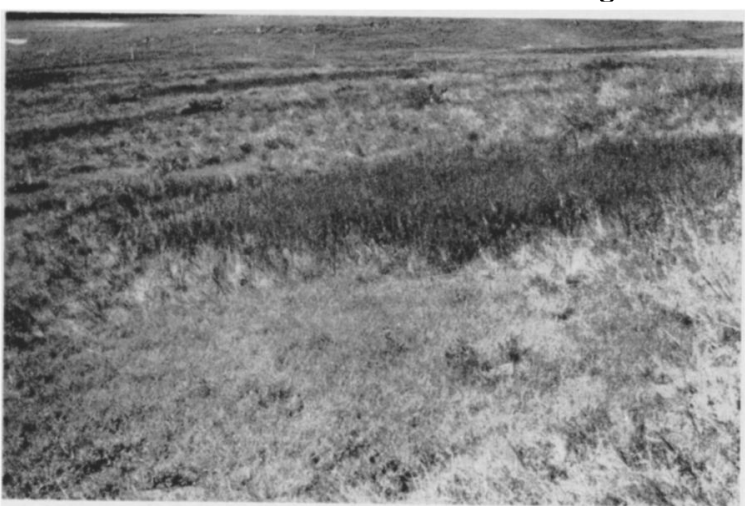

Fig. 52. Alternes of buffalo grass (foreground) and western wheat grass (dark) in the 23-year-old subsere of three-awn grasses. June, 1947.

quently weeds were abundant; wavy-leaved thistle occurred in large patches, open stands of hoary vervain were everywhere, and horseweed was plentiful. Even the annual sunflower (Helianthus annuus) was common. On steep slopes to nearly level land the soil surface was uneven and rough from erosion; on some slopes the soil was almost bare (Fig. 7). Often soil erosion was more rapid than soil formation. An average hasal cover of only 40 to 60 percent was found in the three-awn grass type.

Of approximately 70 species of forbs found in this pasture, only about 15 were common to abundant. These were among those previously listed.

\section{GRAZING IN 1945}

During a period of six weeks after May 5, when 55 head of cattle (55 animal units) were placed in the pasture, grazing was heavy in the lowland buffalo grass-bluegrass type. For not only was bluegrass the earliest perennial in beginning growth but also it was here that the winter annual, hairy chess, made its best growth and was most abundant. The 
cool, moist weather of spring and early summer promoted an excellent development of the cool-season bluegrass and winter annuals. Moreover, this type had been grazed closely the preceding year and there was no dried forage to hinder grazing. The unconsumed hairy chess of 1944 had been trampled to the ground during the fall. Although the herd ranged widely orer the uplands in search of the new crop of little barley and hairy chess, green foliage there was relatively less abundant. There were more of these weedy annual grasses in the more open cover of sand dropseed than where buffalo grass formed closed stands. Small amounts of green forage were also obtained from western wheat grass. During late May and in Jume the new crop of buffalo grass became available for use. This heavy early grazing in lowland and smaller amounts in the other types is shown by the graphs of consumption in Figure 53.

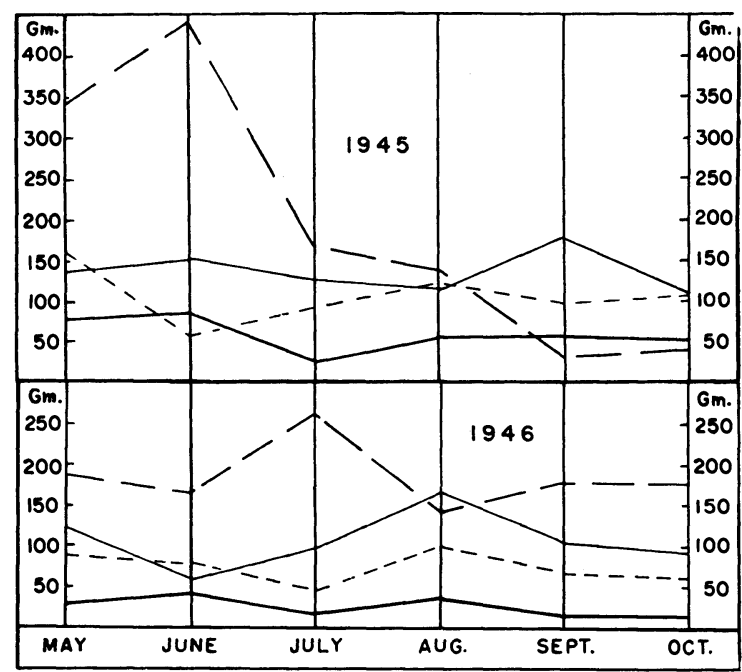

Fig. 53. Average amount of forage in grams consumed per unit area (30 square feet) in the buffalo grass-bluegrass type (heavy, long broken lines), the buffalo grass type (light continuous line), the sand dropseed-buffalo grass type (light, short broken lines), and in the three-awn grass subsere (heavy continuous line) in 1945 and 1946 .

With the ripening of hairy ehess, which overtopped all of the lowland grasses and equaled the height of western wheat grass, grazing in the lowlands became much less pronounced.

In late June and July the highly palatable sand dropseed made an excellent growth. Forage in this type was usually well developed before it was much grazed. It was consumed, along with the accompanying buffalo grass in considerable amounts in July and August and this type supplied good grazing in the fall. Except for a single period of drought in July, the vegetation grew well throughout the summer. With the decline of grazing in lowlands, consumption of buffalo grass on the uplands, where it made an excellent growth in July and until midAugust, became greater and reached a maximum during September (Fig. 53). Grazing late in fall resulted in the removal of practically all of the forage in areas of buffalo grass that had previously received little attention from the cattle. These were on the steeper slopes.

In late fall search for green forage was general, grazing was close, and there was much trampling. The dry hairy chess and various weeds, especially in the valleys, were trampled to the ground. Bluegrass beneath the buckbrush, heretofore unmolested. was now grazed closely and the buckbrush was much trampled. Consumption of forage in the three-awn grass type was uniformly low throughout the summer.

By November 5, very little edible residue was left anywhere on this range, which was greatly overgrazed despite the fact that the cattle also had access to a field of 80 acres where there was a poor stand of sweet clover. No exclosures were maintained in the buckbrush or other roughs, hence the extent of this late grazing is not shown in the graphs.

\section{GRAZING IN 1946}

Grazing began on April 28 when 32 cows and 8 six-months-old calves (about 36 animal units) were turned into the pasture. The spring was early but dry (Fig. 54). On the uplands little barley and buffalo grass were 1.5 to 3 inches tall but new stems were too scattered to provide much forage. Hence, most of the early grazing occurred in the buffalo grass-bluegrass type. Even there the dominant grasses were only an inch or two high; but a little western wheat grass and considerable amounts of hairy chess formed an overstory at 2 to $t$ inches almost throughout.

Moderate drought continued throughout May. On the dry slopes buffalo grass had made very poor growth. On the more level lands, where sand dropseed was also a dominant, the 2-inch buffalo grass was slightly exceeded in height by sand dropseed. Little barley, scattered thickly throughout, was heading at 1 to 4 inches. The scattered patches of western wheat grass had new shoots 4 to 8 inches tall, and hairy chess, averaging somewhat taller, was more widespread. Grasses in the subsere were likewise poorly developed. In fact, scarcely any new forage occurred on eroded slopes. Consequently, grazing on the upland was light, and much of the forage was obtained from the lowland (Fig. 53). Here a fairly continuous stand of buffalo grass 3 inches high, intermixed with bluegrass in the more moist places, was obscured by a 6 - to 8 -inch stand of hairy chess or, in places, by little barley.

Drought continued until late in June (Fig. 54). Both level upland and hillsides became dry. Grazing was very light on uplands and even more confined to the valleys where the grasses were still green and growing (Fig. 53). But late in June forage in the lowlands was largely exhausted, since the winter annuals had almost ceased growth. Bunches of sideoats grama and big bluestem, as well as bluegrass, although well protected by buckbrush or ironweed (Vernonia baldwinii) had been sought and closely 

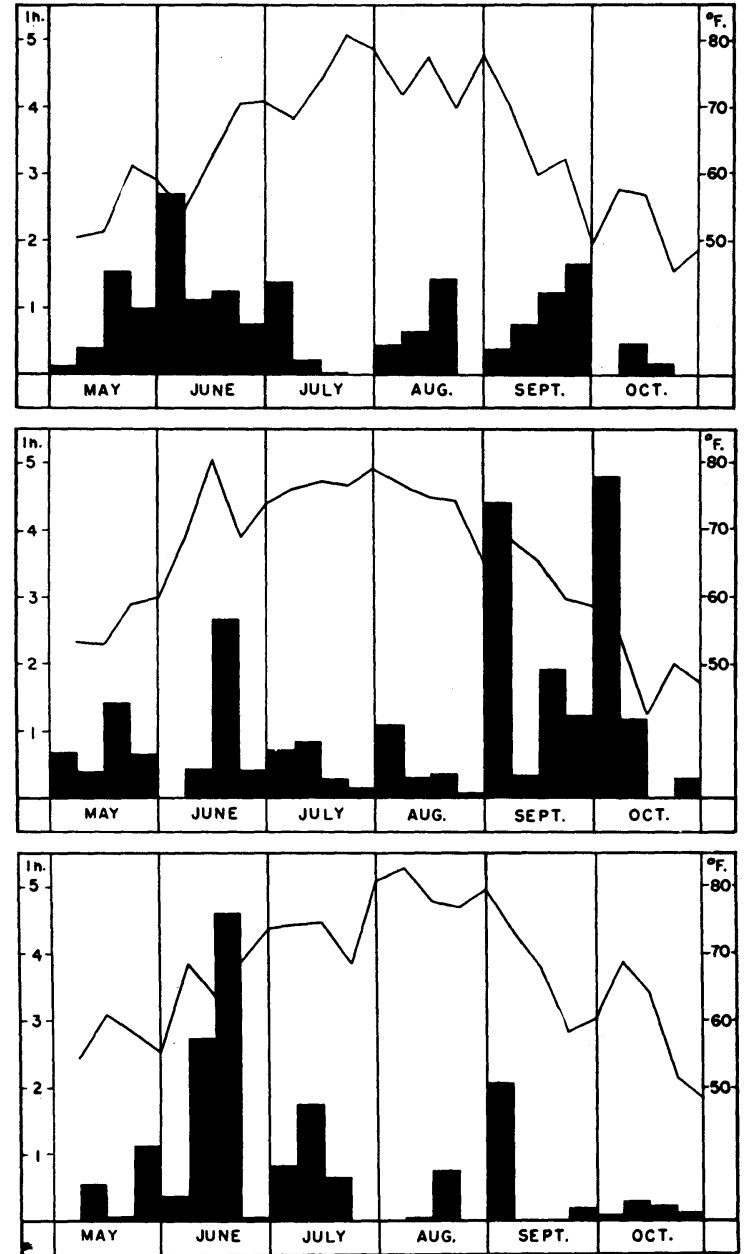

Fig. 54. Total rainfall at Kearney, Nebr., in inches (approximately) by weeks, and average weekly temperatures in degrees Fahrenheit, during the seasons of 1945 (upper), 1946, and 1947 (lower), respectively. In 1945 and 1947 the first week charted is May 5 to 11 , in 1946 , May 2 to 8.

grazed. Although the valleys were kept closely grazed, grazing in the buffalo grass type became more pronounced and was encouraged by a good growth of forage following heavy rains.

Rainfall in late June and in July was sufficient to moisten the entire surface foot of the soil. Buffalo grass dereloped rapidly and supplied much forage. Preference of the livestock for sand dropseed encouraged much grazing in the sand dropseed-buffalo grass type, but the foliage was more sparse than in pure buffalo grass. Both three-awn grasses had developed well and dominated the subsere; cattle appeared to avoid the entire area. Both bluegrass and buffalo grass were repeatedly grazed to an inch or: less in the valleys, except where they were protected by maturing western wheat grass or hairy chess. Various species of Carex and Cyperus were sought and grazed closely.
Buffalo grass made fair to good growth during August. Despite the fact that dried stems were usually intermingled with green ones because of mild drought, grazing was regular in this type, since all of the forage was of the current year's growth. Sand dropseed was eaten in preference to buffalo grass throughout the entire summer, but its foliage was sparse and the flower stalks were scattered. Hence, the sand dropseed-buffalo grass type supplied less forage per unit area. In the subsere both the threeawn grasses had increased greatly in density of stand. The plants were 4 to 12 inches high and seed was abundant. The scattered bunches of sand dropseed, patches of western wheat grass, and even buffalo grass remained almost ungrazed in this type even in late fall. The buffalo grass-bluegrass type continued to provide considerable forage, although much less than during July (Fig. 53).

Growth of buffalo grass decreased in September and there was little or no green foliage. Lower temperatures and abundant soil moisture had promoted thick stands of both hairy chess and little barley, but the plants were small and supplied only very little forage even in October. Forage on some areas was practically all consumed. Renewed growth of bluegrass, sedges, and various perennial grasses in the valleys resulted in increased forage consumption (Fig. 53). During October grazing decreased slightly on the uplands, but continued heavy grazing occurred in the valleys. The remaining protected areas were grazed and nearly all forage of the current year was consumed.

COMPARISON OF CONSUMPTION AND YIELD

Portable exclosures were placed in 8 sampling areas the first year but the number was increased to 18 the second. This permitted quantitative study in 4 or 5 sampling areas in each of the four types. Since the grass under each exclosure and its control was clipped each month, this involved the clipping of 21630 -square-foot areas in 1946. A comparison of graphs of consumption during the 2 years, shows clearly that it was usually lower in 1946 (Fig. 53). This was due in part to the reduction in number of animal units from 55 in 1945 to 36 . Consumption in the buffalo grass type was consistently lower except in August. Seasonal consumption was 1.03 tons the second year compared with 1.30 tons the first. Except for June, 1946, less forage was consumed each month in the sand dropseed-buffalo grass type also. Seasonal consumption was 1.03 and 0.71 tons during the two seasons, respectively. The decrease in consumption on the uplands in fall was due in part to preference for the green forage in the valleys, which was kept green in 1946 by much rain in autumn. In the seral type consumption was greatly reduced each month of the second summer and total consumption was 0.24 ton per acre compared with 0.57 the preceding year.

Compared with 1945, the lowlands were grazed proportionately more than the upland in 1946. This resulted partly from the drier year and partly be- 
cause of a decrease in the total demand for forage. Much less forage was produced on the lowland in 1946 because of the drier spring and consumption was correspondingly lower compared with 1945 . But thereafter grazing was consistently so much greater here that seasonal consumption of the smaller herd (1.78 tons per acre) was almost as great as that of the larger one (1.86 tons) of the preceding year.

The relation of consumption to yield in the several types in 1946 is shown in Figure 55. Where yields were highest on the upland (in the buffalo grass type), they were three times greater than consumption in May and about twice as great in June. By the end of July consumption equaled the yield, after which the cattle lived partly and later largely on forage previously produced. High production in the sand dropseed-buffalo grass type was likewise great in Mav. Here also, it was due largely to the winterannual grasses. On this dry upland, annual grasses grew poorly in June and the early yield of sand dropseed was low. But forage was produced rapidly in July following abundant rainfall. As in the preceding type, yield was consistently lower than consumption in late summer and fall. Because of the abundance of the unpalatable three-awn grasses, yield in the seral area was usually two to three times greater than the amounts of palatable grasses consumed.

The more moist lowlands, characterized by the buffalo grass-bluegrass type but including various tall and mid grasses and a heavy cover of winter annuals, produced the highest yields throughout of any type. The high yield in July is a direct reflection of good rainfall and runoff water from the slopes. Although the excess of yield over consumption was not great, it was maintained until September. Of the excellent yield (2.19 tons per acre) 1.78 tons were consumed. Only 19 percent, consisting largely of coarse stubble and uneaten residues of winter annuals, remained on the soil.

\section{McCan Pasture}

This pasture of 70 acres is one mile northwest of Kearney. It includes three large, round-topped or partially flat-topped hills. They extend in a general east-west direction with narrow intervening valleys. The hills are 40 to 50 feet above the valleys, and the slopes are only moderately steep. The slopes often give way abruptly to steep banks which border the ravines. The valleys, with a single exception, have no ditches but are well-sodded rounded depressions (Figs. 56 and 57). An abundant water supply is available at the south end of this half-mile-long pasture, a well being located in the 10 acres which is used for buildings and farmyard. There is a large pasture on the east; the west side is protected by. a road from blowing dust; there is also a road on the north side, otherwise this pasture is surrounded by cultivated fields. The soil is Holdrege silt loam and it is fairly deep. In the mature soil of level upland the lime layer occurs at a depth of 36 inches.

By the latter part (1939-1940) of the seven years

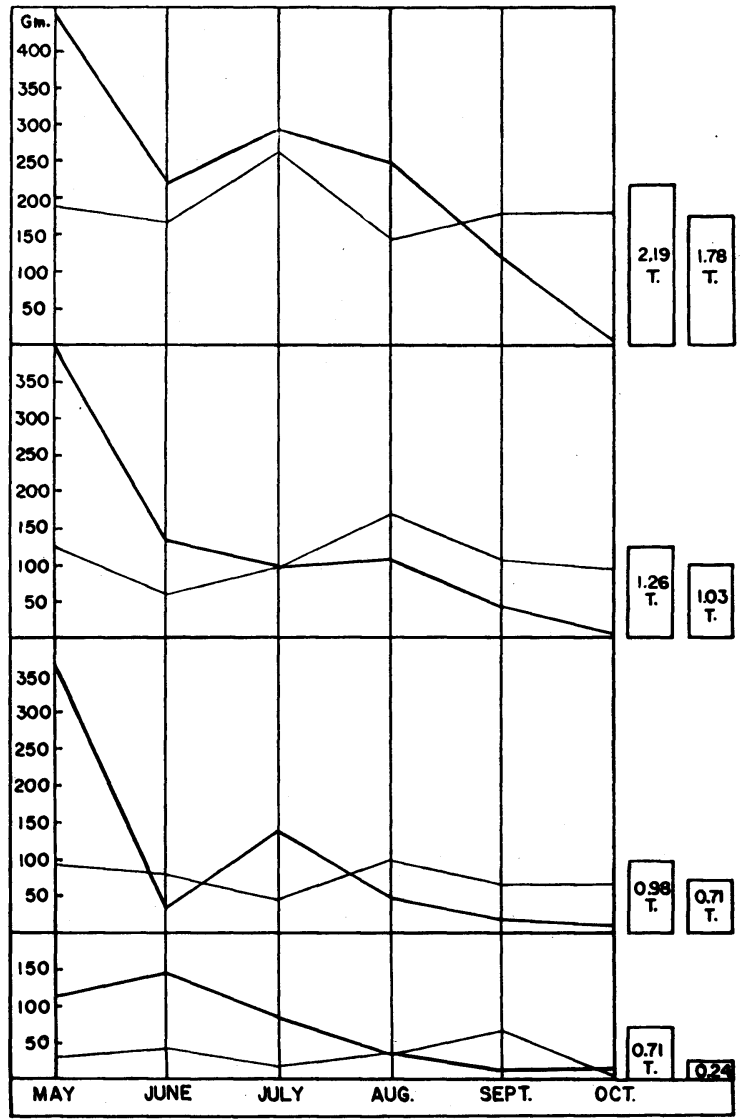

FIG. 55. Average yield (heavy lines) and average consumption (light lines) in grams per unit area in each of the four grazing types in the Sheen pasture in 1946. Seasonal yields and consumption are shown in tons per acre. From top to bottom the types are buffalo grassbluegrass, buffalo grass, sand dropseed-buffalo grass, and three-awn grass.

of drought the pasture had lost nearly all of its cover of perennial short grasses. This was an almost general phenomenon in the mixed prairie (Weaver \& Albertson 1940). It was in the first weed stage (Weaver \& Albertson 1944). Only sparse patches of short grasses remained. These were mostly buffalo grass but small amounts of blue grama also occurred. The owner feared that the pasture was ruined. He harrowed the land in order to loosen the Russian thistles (Salsola pestifer) so that they might be blown away. This flattened sunflowers, lamb's quarters, and pigweeds on the ground, which was advantageous to buffalo grass in relation to light. This grass developed rapidly with the cessation of drought. Thus, from a wilderness of weeds the succession proceeded so rapidly that in 1945 revegetation was nearing completion. This was due largely to the excellent growth and rapid spreading of buffalo grass, which has been deseribed by Weaver and Albertson (1944) as a general phenomenon of the central mixed prairies. 


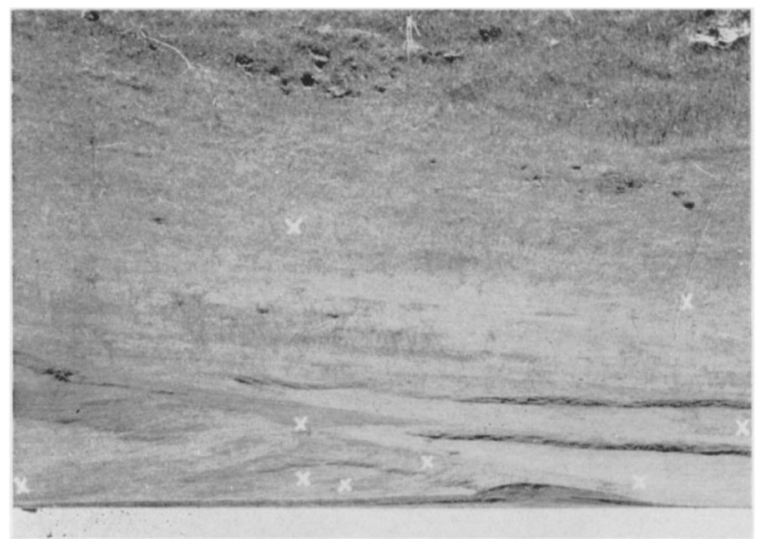

FIG. 56. General view in the southern part of the MeCan pasture showing nature of the topography and the excellent cover of buffalo grass in which there are relatively few weeds. Positions of several exclosures in 1947 are indicated by $x$.

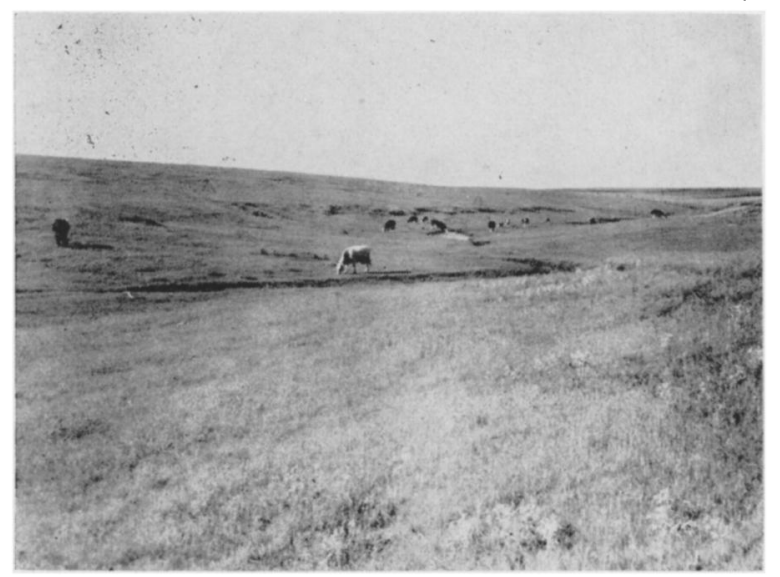

Fig. 57. Cattle grazing on the lowland of the MeCan pasture on June 19, 1947. Grazing on the uplands was not general.

By 1943 buffalo grass carpeted the valleys and sides of even the steepest slopes. Blue grama resisted extinction by drought on the drier hilltops where buffalo grass succumbed, and had healed over all but a few of the formerly extensive bared places. The last remnants of such subsere weeds as annual sunflower, lamb's quarters, and horseweed were represented by old stems only in 1945 . While the basal cover varied from 60 to 95 percent, the average percentage was about 80 . Little barley was an important component of the grassland. It formed a continuous and often thick cover except on the most grazed ridges. Often there were 200 to 250 plants per square foot. In spring it gave a yellow-green tone to the landscape, since it was practically continuous over three-fourths of the pasture despite the dense sod.

The most abundant and most widely distributed grass, except on certain ridges where blue grama grew locally in nearly pure stands, was buffalo grass. Other species, in order of their importance, were Kentucky bluegrass, found only in the valleys, west- ern wheat grass which occurred sparingly on both slopes and in valleys but constituted 5 percent or less of the cover, and big bluestem in the valleys or as remnants with side-oats grama along the banks of the lower slopes. Six-weeks fescue was scattered widely but in small amounts. Sand dropseed was widely but sparsely distributed as a relict from the early grass stage. Hairy chess and downy brome were almost rare as were also tumblegrass and hairy grama. All of these grasses, with the single exception of western wheat grass, were kept closely grazed.

Among approximately 70 native forbs only about 10 were common to abundant. These were Grindelia squarrosa, Hosackia americana, Psoralea argophylla, Ambrosia psilostachya, Gaura coccinea, Liatris punctata, Ratibida columnaris, Malvastrum coccineum, Ionoxalis violacea and Cathartolinum rigidum. Grindelia and Ambrosia were rarely eaten and the others provided only a small amount of forage. A considerable number, as Astragalus shortianus, Geoprumnon plattense, Oxytropis lamberti, Parosela enneandra, and Sideranthus spinulosus, were of local occurrence and grew mostly on the steep banks. Repeated grazing and the dense sod of buffalo grass, which covered the soil like a thick rug, suppressed the forbs.

Except for Grindelia squarrosa, Ambrosia psilostachya, and Leptilon canadense (in certain years) the pasture was remarkably free of weeds. Grindelia was sufficiently abundant only on a few slopes to interfere with grazing, and patches of Ambrosia were small. Others of much less importance were Verbena stricta and Cirsium undulatum. The soil had a continuous cover of litter a few millimeters thick, and bare ground was seldom exposed.

\section{GRAZING IN 1945}

From early spring until mid-June grazing by 13 cattle and 5 horses (18 animal units) was mostly confined to the valleys. The spring was cool and moist and little barley grew in great abundance and was highly preferred to buffalo grass. After grazing to a height of 1 to 2 inches, this weedy, winter annual recovered rapidly and was repeatedly grazed. Amounts removed were 463 grams per exclosure or $3 / 4$ ton per acre in May, and 255 grams in June. Little barley was scattered thickly over the uplands as well. In grazing here some buffalo grass was also consumed. Since little barley was 4 to 6 inches tall and the new buffalo grass only 2 inches as late as June 5, it seems certain that the bulk of the forage was little barley (Fig. 41). Forage of the previous year's growth need not be considered since it was flattened on the soil by heavy rains and wet snows of early spring, and lay below the grazing level.

After the little barley had produced its spikes (and in the previously grazed patches had ceased growth and began to dry) there was a transition in the grazing trend away from this grass and toward the rapidly developing buffalo grass. This transition period occurred late in June. Thus, from early July to the middle of August grazing was almost exclu- 
sively in places which had been closely grazed the preceding year. Here the young buffalo grass was very much liked, and it was consumed in considerable amounts. In general these places were on the hilltops and upper slopes and in the valleys, but they also occurred on lower slopes. During this period the mid-slopes or other places where previous grazing had been light (approximately half of the pasture) were scarcely grazed.

By the middle of August a third shift in grazing occurred. Available soil moisture was almost exhausted and temperatures were high (Fig. 54). Grasses in the most favored grazing areas were dry and had ceased growing. Hence, thereafter grazing was done on the mid-slopes where the vegetation was dense but still green. It was less palatable, partly because of the intermixture of the dried stems of little barley. Because of light rains in August the grass remained green for several weeks. The buffalo grass dried permanently about September 1 , but it was grazed long after it was cured (Fig. 58). Small amounts of bluegrass, various sedges, and big bluestem were also elosely grazed where they grew in the valleys. Dense stands of little barley were promoted by the fall rains but the plants failed to reach a height sufficient to supply much late grazing. On the hillsides old grazing areas were enlarged, new ones were started, and the cured buffalo grass was removed in large amounts. Cattle were taken from the pasture early in November.

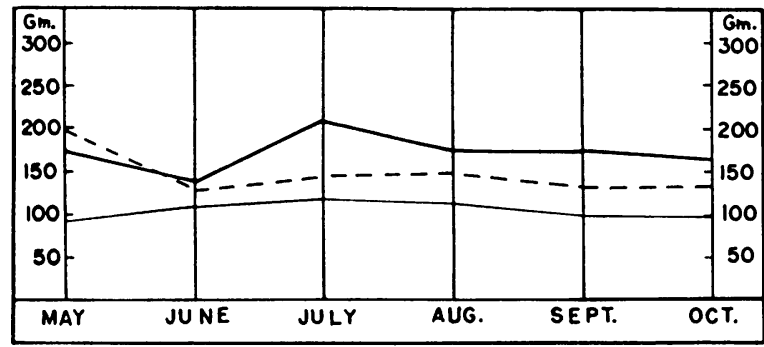

Fig. 58. Average amount of forage in grams consumed per unit area (30 square feet) in the McCan pasture each month of the growing season of 1945 (heavy line), 1946 (light broken line), and 1947 (light line). The amounts recorded for the month of May also include forage consumed earlier in spring.

At the end of the season it was clear that the southern half of the pasture near the well had been grazed about twice as heavily as the more distant northern half. On this more closely grazed part about two-thirds of the vegetation was uniformly removed to 0.5-1 inch and much of the remainder to 2 inches. Perhaps one-fourth of the area, especially on the steeper slopes, was lightly grazed to 4 inches. In contrast, in the more distant half about one-third was closely grazed but the rest was little grazed except in patches of a few square feet. Over most of this lightly grazed part new foliage was 5 to 6 inches tall but some had been removed to a height of 3 to 4 inches. There was a distinct preference for grazing in more open stands of buffalo grass rather than in places where the foliage was very heavy and densely matted.

\section{GRAZING IN 1946}

Livestock was turned into the pasture on March 25. There were 13 cattle and 5 horses as in the preceding year, but three steers were only yearlings. Hence the animal units were only about 17 . Grazing during April was a continuation of the process started in autumn of reducing the amount of forage which had accumulated in 1945. Although little barley was thickly intermixed with buffalo grass throughout the pasture, its height growth did not exceed that of the short grass. It supplied some inducement for the consumption of the cured forage but added little to its bulk.

Little barley, because of dry soil and stunted growth in May, fell far short of providing an amount of forage equal to that of the preceding year. Nor was much green forage supplied by it in the valleys, despite the fact that here it was kept continuously grazed to 1 inch. Also the considerable areas formerly held by bluegrass were now almost all occupied by buffalo grass, which becomes green much later (Fig. 59). Hence, the eattle roamed widely over the upland as well, seeking the new green foliage of little barley. It grew tallest in places ungrazed the previous year, since here snow had accumulated and the dried forage protected the soil from high evaporation. Thus, all through the month large amounts of the last year's forage were consumed.

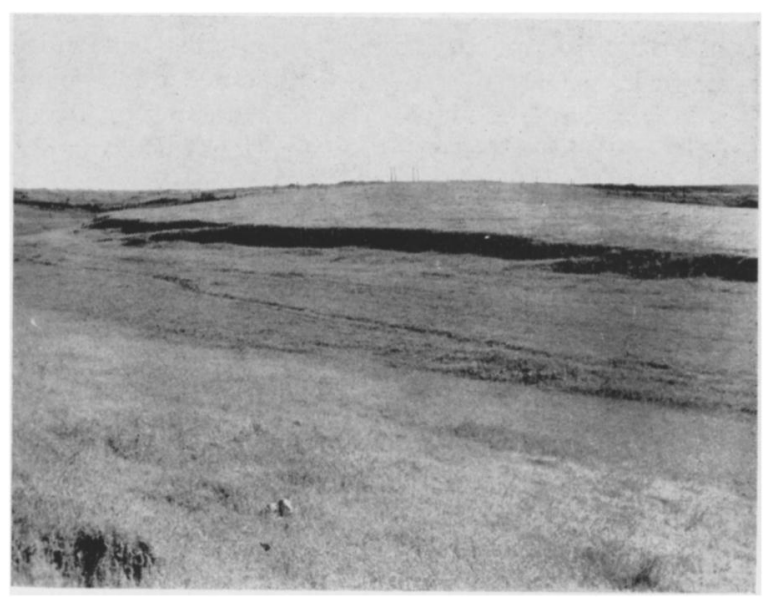

Fig. 59. Buffalo grass in a ravine. It has almost entirely replaced bluegrass. This sod, which was very dense in 1947, was maintained even a short distance from the windmill.

A similar type of grazing eontinued throughout June. Because of the drought the usually productive valleys provided comparatively little forage (Fig. 54). Moreover, the areas which had been closely grazed the preceding year, and more or less this year after the new growth gradually developed in May, were now dry and no longer grazed. This included fully half of the pasture. Hence, there was much selective grazing in areas previously ungrazed. This was not close and uniform: only the top 2 to 3 inches 
was taken. Finally the entire area with taller foliage was grazed and most of it was reduced to a height of 3 to 4 inches.

Adequate rains occurred after the middle of June. Soon new forage developed in previously grazed upland areas and especially in the valleys so that grazing of the old forage was abandoned. There was a distinct shift to the type of grazing normal for this season, which was grazing in areas previously closely grazed.

Rainfall in July was sufficient to promote a fair to good growth of the grasses, although only the surface foot of soil was moist. In the valleys grazing was usually to a height of an inch. Grazing was also general on the slopes and hilltops and usually to 1-2 inches. Exceptions to close grazing occurred occasionally, especially at the north end, where some forage was reduced to a height of only 3 to 4 inches. Buffalo grass, owing to scarcity of available water, was much less luxuriant than in 1945 . When periods of drought occurred, most of the buffalo grass became dry and dormant and hence less palatable on the general area where grazing had been close. But it remained green where protected by dry forage of the preceding year. Hence at these times there was a distinct shifting of grazing to these areas. This was especially pronounced late in August.

Rainfall during September was high and wet the soil to a depth of 2 feet. But temperatures were relatively low and the grasses grew very slowly (Fig. 54). Since there was scarcely any new forage produced the livestock gradually depleted that which remained. In October the soil moisture was replenished to a depth of 4 feet, but this scarcely affected the current year's forage production. Conversely, there was some leaching of nutrients and the value of the forage was reduced. The third of the pasture nearest the well was uniformly and closely grazed to 1 or even 0.5 inch. Similar conditions, except for a few small patches which were grazed high, maintained orer the central part of the pasture. Even in the northern portion the extensive areas formerly grazed but little had been gradually reduced to a height of 2 inches, and even where the most debris remained in 1945 the grasses were grazed to a height of 3 to 4 inches. Formerly closely grazed places were kept in that condition. Thus, the entire pasture was grazed closely, or only a small portion moderately. In October, it seemed clear that practically all of the forage produced during the year had been consumed.

\section{GRAZING IN 1947}

Grazing began on April 28. The herd consisted of 12 animal units, 3 of which were horses. Since the grass had nearly all been eaten the preceding year and little new growth had occurred, there was scarcely enough forage to satisfy the animals. They ranged widely seeking out the dunged areas where the buffalo grass and little barley were somewhat taller. Although the subsoil was moist to a depth of about 4 feet, regetation developed slowly because of dry surface soil and continued unseasonably cold weather. Buffalo grass had not renewed growth and little barley was only about an inch high. Vegetation in the valleys, usually lush at this season, was even less developed than that on the slopes. The small amount of bluegrass that remained was stunted by drought. Milch cows received a grain supplement until the pasture improved (Fig. 58).

By May 15 the pasture was green everywhere. Although buffalo grass developed slowly, little barley grew thickly throughout and was 4 to 6 inches tall as were also many forbs. Forage in the valleys was growing rapidly and here the grass was kept closely grazed. This forage was preferred to any on the upland except that in the small, bright green, fertilized spots which were also kept closely grazed. During June general grazing continued in the lowlands but only selective grazing elsewhere. There was an abundance of forage in the valleys. The small remaining areas of bluegrass were kept closely grazed. On the upland the spikes of the thick, continuous stand of little barley were ripening at heights of 4 to 7 inches, and quite above the 2 - to 4 -inch buffalo grass, which grew rapidly only late in June, following heavy rainfall (Fig. 54). The livestock appeared well fed and spent much time at rest, which was quite in contrast to their continuous search for forage earlier in the season.

In July the spikes of little barley shattered. There was a luxuriant growth of buffalo grass usually 4 to 5 inches tall; forbs too were well developed despite their retarded growth in spring. The grazing pattern changed only slightly from that of June. The livestock had been unable to keep the lowlands uniformly grazed and they now spent some time on the slopes, especially the lower ones. The green, fertilized spots throughout the pasture were kept grazed to 1-1.5 inches, and there was a little light general grazing. Total consumption of forage was highest during July (Fig. 58).

By August 1 all of the little barley was dead and the heads were shattered. Six-weeks fescue was also disintegrating. The livestock found the luxuriant buffalo grass on uplands quite as attractive as vegetation in the valleys, where only recently grazed patches were utilized and the more rank growth was avoided. The livestock spent comparatively little time in grazing, so abundant was the forage, and seldom reached the more distant side of the pasture, where only the fertilized spots were kept grazed. Despite the fact that lower slopes near the paths were the most favored grazing places, only half of the grass on the lowlands was closely grazed.

Growth of vegetation decreased late in August, which was hot and dry, and later almost ceased. The livestock was no longer able to graze new forage in previously grazed places but was forced to feed on the mature forage in the ungrazed areas. This change in the grazing pattern was similar to that of the previous year and occurred at about the same time.

During September and October grazing consisted 
almost entirely of consuming the forage which had been produced in summer. Subsoil moisture and a heavy rain in September kept the short grass in fairly good condition. It was green at the base. It was less succulent than when growing but palatable and nutritious.

The third of the pasture nearest the well was grazed to 1-3 inches. The central third was grazed only moderately; extensive areas occurred where the grass was 3 to 4 inches tall. Forage in the northern part of the pasture was abundant. Much of it was ungrazed and a height of 4 to 5 inches was common. In only relatively few places was the grass reduced to a height of an inch.

Summarizing, during the good year for growth, 1945 , the pasture at the north end was somewhat undergrazed. In the dry year which followed, practically all of the forage produced was consumed. But with a reduction of the herd in 1947 from 18 to 12 animal units, and a good growing season (except for July drought) the pasture as a whole was undergrazed. With greatly varying seasons and minor cycles of wet and dry years, the proper adjustment of the size of the herd to a given range is indeed a difficult problem.

\section{COMPARISON OF CONSUMPTION AND YIELD}

In 1945 portable exclosures were used in 8 sampling areas in various sites in the 70 -acre pasture. The number was increased to 18 in 1947. Monthly consumption during the three grazing seasons is shown in Figure 58. The graph for 1946 is remarkably similar to that of the preceding year. Both are quite regular throughout the grazing season. The fact that the horses and nearly all of the cattle were mature animals may account for this regularity. With growing stock there is usually a distinct upturn in quantity of forage consumption in September. With buffalo grass, however, there is little decrease in its nutritive value upon curing, a fact which may account for the uniform trend of the graph. Differences in amounts of forage consumed during the two years may be due to several factors. First is the decrease in the number of animal units from 18 to 17. Secondly, forage in general was less succulent during the drier year of 1946. Moreover, the amount available was much less than in 1945 .

With a further reduction in 1947 to only 12 animal units, the graph of forage consumption was continuously lowest (Fig. 58). The very moderate consumption of forage in early spring is clearly a result of its scarcity. Seasonal trend is practically the same as in preceding years.

Monthly and annual yields and consumption are shown in Figure 60. Even casual examination shows that the yield was highest in 1945 and lowest in 1946; the third year yield was intermediate. The greatest difference occurred in May and June. This was due in part to a later and drier season in 1946 , but especially to the excellent growth of little barley in 1945 and 1947. The high yields in May, 400 grams or more, followed by rapid decrease in June and still more in July, is the same for both 1945 and 1947. A slight increase in August followed by very low yields in September and October (75 grams or less) is also common to both years. But during the cold dry spring in 1946, yield in May was low (less than 200 grams). Otherwise, except for the absence of an increased yield in August, the trend of the graph is similar to that of the preceding and the following year. Yields greatly exceeded consumption in May, except in 1946 when they were about equal. It was always greater in June and, with one exception, continuously as great or greater than consumption until September. Thereafter much of the forage consumed was that produced earlier in the year.

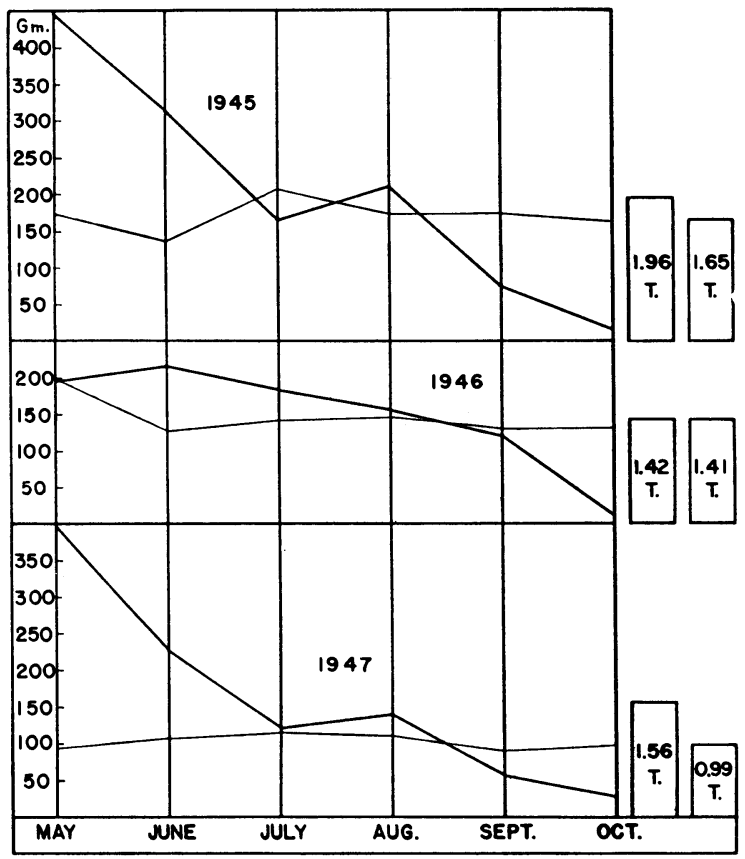

FIG. 60. Average yield (heavy lines) and average consumption (light lines) in grams per unit area each month of the growing season of 1945, 1946, and 1947 . Seasonal yield and consumption are shown in tons per acre.

Seasonal yield was highest the first year, 1.96 tons per acre. The amount consumed was 1.65 tons or 84 percent of the yield. Since the south half of the pasture nearest the well was grazed very closely late in autumn, this left uneaten about 30 percent of the forage in the more distant part. Yield was so greatly reduced in the drier year, 1946, that of the 1.42 tons per acre practically all (99 percent) was consumed. This was shown by the close and even grazing everywhere in October. Of the intermediate yield, 1.56 tons per acre in 1947, the reduced herd consumed only 0.99 ton or 63 percent.

That the pasture was adequately sampled may be seen by comparing the results from the original exclosures in 1947 with a similar group of 9 new ex- 
closures used here for the first time. They were placed in 9 new sampling areas as similar as possible to those sampled by the first group in 1947 but 40 to 100 yards distant. The data obtained from the two groups are shown in Table 9.

TABLE 9. Average monthly and total consumption and average monthly and total yield in grams from two similar sets of sampling areas in 1947 .

\begin{tabular}{l|r|r|r|r|r|r|r|r}
\hline \hline Exclosures & May & June & July & Aug. & Sept. & Oct. & Total \\
\hline & Consumption \\
First group....... & 819 & 916 & 1,061 & 1,029 & 893 & 878 & 5,596 \\
Second group...... & 853 & 988 & 1,050 & 968 & 884 & 893 & 5.636 \\
Yield \\
First group........ & 3,463 & 2,223 & 985 & 1,181 & 407 & 391 & 8,650 \\
Second group...... & 3,718 & 1,898 & 1,191 & 1,378 & 655 & 98 & 8,941 \\
\hline
\end{tabular}

From the preceding data it may be concluded that the pasture was understocked the last year. About 15 animal units or 5 acres per animal unit seems to be a proper rate of stocking this excellent buffalo grass pasture provided a more equal distribution of grazing could be had. This might be attained by fencing to keep the cattle in the far end of the pasture in the morning, and the placing of salt just south of the fence where both salt and water could be had in the afternoon. Further studies now well under way will greatly increase our knowledge of this great pasture region.

The writers wish to express their gratitude to Dr. R. W. Darland who accompanied them on many field trips and assisted in other ways.

\section{SUMMARY}

A portion of the Dissected Loess Plains of central Nebraska, several thousand square miles in area, occupies a region directly southeast of the Sandhills and north of the Platte River. It extends over four large counties and includes the territory between Broken Bow and Ord on the north and Lexington, Kearney, and Grand Island on the south.

The area is developed principally on mantle rock materials of Pleistocene age. During middle and later Pleistocene time the interfluve areas received relatively thick mantles of wind-blown dust known as loess. Much of this was blown up from alluvial flats along the through valleys of the region. The Sandhills released much Tertiary and Pleistocene loess-forming material which contributed directly or indirectly to the Loveland and Peorian deposits. The aggregate thickness of the loess mantle approaches 150 feet or more in places.

Headwater erosion into the loess plain has rapidly developed the characteristic canyon topography of the region. Once the sod and thin soil cap of the upland plain is removed by undercutting, the relatively coarse silts of the loess erode rapidly.

Before the Peorian loess was deposited on it, a dark soil with a clayey subsoil was developed at the top of the Loveland loess. Water easily enters and penetrates downward through the Peorian loess often to 30 or 40 feet. At the contact with Loveland loess its further penetration is greatly restricted. Hence, the ground water movement is directed laterally toward the valley or canyon sides where water is discharged as springs and causes the overlying Peorian loess to slip or slide valleyward. Catsteps are thus developed. These are a typical feature of the side slopes of the uplands.

Average elevation of the upland plain is about 2,200 feet above sea level. Over the greater part of the area it has been thoroughly dissected. The bluffs and hills are often 100 to 150 feet higher than the valleys between them. Comparatively level areas are not extensive. Nearly all the area is well drained by streams and rivers-North, Middle, and South Loup Rivers, and Wood River-southeastward into the Platte River. Runoff is usually excessive and erosion is severe.

The climate is characterized by moderately long, cold winters and a fairly long growing season with hot summers. Annual precipitation averages about 23 inches, evaporation is high, wind movement is fairly constant and often high, and mid and late summer droughts are frequent.

The soils are constantly rejuvenated, chiefly by deposition of wind-blown dust. Well developed soils of the uplands are predominately those of the Holdrege series. The friable, dark-grayish brown silt loam is about 12 inches deep. It is underlaid by a silty clay loam subsoil to a depth of 3 or more feet. The lime layer characteristic of Chernozems occurs often between depths of 3 and 6 feet. The soil is approximately neutral in reaction.

The light-colored Colby soils, the second chief type, may be regarded as immature. Colby silt loam varies from dark grayish brown to ash-gray. The A horizon is only 4 to 12 inches deep. The subsoil or B horizon composes a part of the second foot. In many places the surface layers have been entirely removed by erosion, exposing the light, yellowishgray parent loess.

Both soils are very fine textured. The degree of aggregation (14 to 24 percent) is very low. Organic matter is about 4 to 5 percent in the surface foot, and nitrogen 0.110 to 0.194 percent. Because of these characteristics, the soils are easily eroded and the maintenance of a cover of vegetation is important.

The grasses and forbs develop well-branched, deeply penetrating root systems. Buffalo grass penetrates to 4-6 feet, western wheat grass to 8-10 feet, and various perennial forbs to 15 feet or more in the mellow, moist loess.

Although the land was homesteaded about 1870, a third to a half of it is still under native grass. It is recommended by the U. S. Soil Conservation Service that the steeper uplands should always be protected by a cover of grass.

There were four communities or types of grassland in the mixed prairie association of these loes: hills. In the short-grass type or faciation blue grama (Bouteloua gracilis) was far more abundant than buffalo grass (Buchloe dactyloides). Buffalo grass 
was often entirely absent in virgin ungrazed prairie.

Short grasses dominated in the drier portions of most prairies, usually in almost pure stands or even where there was an intermixture of taller grasses. These sites included various slopes but especially those where runoff was high. In some places blue grama was intermixed or alternated with rather extensive patches of buffalo grass. In other places, even on dry slopes, the short grasses gave way to mid grasses. The type was characterized by an overstory of hairy chess (Bromus commutatus), an invader during drought.

The mid- and tall-grass type occurred typically on the lower slopes of hills and in ravines partially protected from wind and sun and where runoff water from the slopes supplemented rainfall. Where the soil had slumped to produce catsteps on the hillsides, vegetation was of much the same type. Chief species of this postclimax associes were big bluestem (Andropogon furcatus), side-oats grama (Bouteloua curtipendula), western wheat grass (Agropyron smithii), switchgrass (Panicum virgatum), and nodding wild rye (Elymus canadensis).

The typical expression of the association was shown in the mixed short- and taller-grass type. This community occurred in transitional areas of considerable extent where species from the two preceding types grew more or less in equal abundance forming the characteristic layered vegetation of mixed prairie. Here big bluestem largely replaced little bluestem (Andropogon scoparius) which had mostly succumbed to drought. Side-oats grama and western wheat grass were often abundant. Secondary species of greatest abundance, which also occurred in preceding types, were Muhlenbergia cuspidata, Poa pratensis, Koeleria cristata, Sporobolus cryptandrus, and Panicum scribnerianum.

The western wheat grass type was present locally in many different prairies. It often covered a single ridge or valley or a particular slope. But often it dominated very extensive areas or entire prairies almost to the exclusion of other grasses. Western wheat grass spread widely when the soil was partly bared by drought. Sometimes it had an understory of blue grama, or more frequently one of hairy chess. But it usually occurred in pure stands, forming an extensive consociation. Its boundaries were mostly more distinct than those of the three preceding types which were often indefinite, and fragments of one community frequently occurred as patches or islands in the others.

About 24 principal species of forbs occurred in the several communities. Amorpha canescens, a halfshrub, was most abundant, conspicuous, and widely distributed. About 50 other forbs were of secondary importance. Drought had taken its toll and recovery was incomplete. Certain shrubs formed thickets bordering ravines.

The grassland has been used chiefly for grazing, largely for summer range, especially for cattle. Con- sequently the vegetation has undergone various changes, somewhat in proportion to the intensity of grazing. The ranges varied in size from 80 acres to a square mile or more.

The vegetation consisted chiefly of blue grama, although buffalo grass was found in moderate amounts and in old, closely grazed pastures abundantly. These occurred mostly where crop production was the chief industry. Such pastures were usually smaller and often overstocked.

Big bluestem was the chief tall pasture grass; sideoats grama was less abundant except on eatsteps and steep banks. Western wheat grass occurred sparingly to abundantly. These and other taller grasses were regularly found in places favored by receiving runoff water. In general, the cover had been greatly disturbed by drought or dust coverage. Often sand dropseed (Sporobolus cryptandrus) was common, purple three-awn (Aristida purpurea) occurred on bared slopes, and hairy chess was abundant.

Under grazing, the tall and mid grasses were reduced in vigor much more rapidly than were the short grasses which had more foliage close to the soil. Grazing and drought had more or less completely removed the mid-grass layer and many species of the ground layer. The remaining species were now more widely spaced.

After long periods of close grazing and trampling, the taller grasses in the ravines, on their steep banks, and even on the catsteps, were replaced by blue grama and buffalo grass. Long continued heavy grazing was less harmful to the sod-forming buffalo grass than it was to the bunches of blue grama. Buffalo grass also recovered and spread more rapidly over ridges and bared slopes than did blue grama.

Of 29 ranges carefully examined 9 were characterized by buffalo grass and 8 by blue grama, 15 percent or less being composed of the other short grass, which ranked second. But where larger percentages of the second ranking grass were present, buffalo grass exceeded blue grama in only 3 ranges, while blue grama exceeded buffalo grass in 7 .

Grazing was light, moderate, or none in 18 pastures; only 9 were overgrazed. The average basal cover usually ranged between 30 to 60 percent in the poorer parts of the range and 40 to 90 in the better portions.

The most abundant weedy annual grasses were little barley (Hordeum pusillum), six-weeks fescue (Festuca octoflora hirtella), and hairy chess. Where abundant, little barley furnished much forage in spring. Hairy chess, common in nearly all ranges, has a high forage value in spring and early summer.

About 30 species of native forbs were found to occur widely and often abundantly. They provided a valuable variety in the diet of livestock grazing native ranges.

Chief introduced weeds were hoary vervain ( Verbena stricta), prostrate vervain ( $\nabla$. bracteosa), and horseweed (Leptilon candense). Horseweed was 
eaten when young but often grew so thickly that later it hindered uniform grazing.

Two pastures near Kearney were selected for a study of the monthly and annual yield and consumption of forage. The seasonal grazing patterns varied mostly with the type of vegetation available to the livestock, its period of development, and, consequently its palatability. They also varied with the grazing pressure.

Monthly consumption of forage was ascertained in 3 or 4 sampling areas in each grazing type. This was accomplished by elipping the forage close to the soil at the end of each month in 30-square-foot portable exclosures and in adjacent grazed areas of a similar size. The air-dry weight of the first lot of forage minus that which was uneaten in the adjacent area equaled the amount consumed. New locations were used each month.

Yield was ascertained each month by subtracting from the dry-weight of the forage in an exclosure at the end of the month the dry-weight of the approximate amount that occurred there at the beginning of the month.

During 1945, a year favorable for growth, 55 animal units of cattle consumed 1.86 tons of forage per acre in the buffalo grass-bluegrass type on the lowlands. Annual consumption in the buffalo grass type on the hillsides was 1.30 tons. In the more open sand dropseed-buffalo grass type on hilltops only 1.03 tons of forage were consumed, and in the seral type dominated by three-awn grasses only 0.57 ton of forage was eaten. This pasture was 160 acres in extent, but almost half of it was a 23-year-old subsere following breaking.

During the drier year which followed, a reduced herd of 36 animal units consumed 1.78 tons of a 2.19 tons yield on the lowlands. In the buffalo grass type, yield was 1.26 tons and consumption 1.03. The sand dropseed-buffalo grass type yielded 0.98 ton; 0.71 ton was consumed. In the subsere, yield and consumption were 0.71 and 0.24 ton, respectively.

The second pasture consisted of 70 acres of excellent, almost pure buffalo grass. Grazing patterns during the three years 1945 to 1947 inclusive, varied with lateness of spring and especially with precipitation. Yield, as in the preceding pasture, exceeded consumption in spring and early summer, but it was usually exceeded by consumption after August. Here 18 sampling areas were used.

The first year 18 animal units consumed 1.65 tons of forage per acre of the 1.96 tons yield. The next year, which was less favorable for growth, 17 animal units consumed 99 percent of the 1.42 tons yield per acre. The third year, which was more favorable for growth, 12 animal units consumed 0.99 ton per acre of the 1.56 tons yield.

Thus, under good management, a stocking rate of about 15 animal units or approximately 5 acres per animal unit seems to be a proper one in this excellent buffalo grass pasture which is typical of many others throughout these loess hills.

\section{LITERATURE CITED}

Albertson, F. W. 1937. Ecology of mixed prairie in west central Kansas. Ecol. Monog. 7 : 481-547.

Albertson, F. W., \& J. E. Weaver. 1942. History of the native vegetation of western Kansas during seven years of continuous drought. Ecol. Monog. 12: 23-51.

Bertramson, B. R., \& H. F. Rhoades. 1938. The effects of cropping and manure applications on some physical properties of a heavy soil in eastern Nebraska. Soil Sci. Soc. Amer. Proc. 3: 32-36.

Bouyoucos, G. J. 1936. Directions for making mechanical analyses of soils by the hydrometer method. Soil Sci. 42 : 225-228.

Condra, G. E., E. C. Reed, \& E. D. Gordon. 1947. Correlation of the Pleistocene deposits of Nebraska. Neb. Geol. Surv. Bul. 15. Univ. Neb. Conserv. \& Surv. Div.

Fuelleman, R. F., \& W. L. Burlison. 1939. Pasture yields and consumption under grazing conditions. Jour. Amer. Soc. Agron. 31 : 399-412.

Hayes, F. A., et al. 1926. Soil survey of Custer county, Nebraska. U. S. Dept. Agr., Bur. Chem. and Soils.

Hayes, F. A., et al. 1928. Soil survey of Buffalo county, Nebraska. U. S. Dept. Agr., Bur. Chem. and Soils.

Joint Com., Am. Soc. Agron., Am. Dairy Sci. Assoc., \& Am. Soc. Animal Production. 1943. Preliminary report on pasture investigations and technique. Jour. Dairy Sci. 26: 353-369.

Klingman, D. L., S. R. Miles, \& G. O. Mott. 1943. The ang method for determining consumption and yielil of pasture herbage. Jour. Amer. Soc. Agron. 35: 739746.

Lugn, A. L. 1935. The Pleistocene geology of Nebraska. Neb. Geol. Surv. Bul. 10 (2nd Ser.).

Shively, S. B., \& J. E. Weaver. 1939. Amount of underground plant materials in different grassland climates. Univ. Neb. Conserv. and Surv. Div. Bul. 21.

Smith, H. W., \& M. D. Weldon. 1940. A comparison of some methods for the determination of soil organic matter. Soil Sei. Soc. Amer. Proc. 5: 177-182.

Thorp, J. 1948. Soil development under natural grass Year Book of Agr., U. S. Dept. Agr.

Tolstead, W. L. 1942. Vegetation of the northern part of Cherry county, Nebraska. Ecol. Monog. 12 : 255-292.

Weaver, J. E. 1919. The ecological relations of roots. Carn. Inst. Wash. Pub. 286.

1942. Competition of western wheat grass with relict vegetation of prairie. Am. Jour. Bot. 29: 366-372. 1948. Unpublished manuscript.

Weaver, J. E., \& F. W. Albertson. 1940. Deterioration of midwestern ranges. Ecology 21: 216-236.

1940a. Deterioration of grassland from stability to denudation with decrease in soil moisture. Bot. Gaz. 101 : 598-624.

1943. Resurvey of grasses, forbs, and underground plant parts at the end of the great drought. Ecol. IIonog. 13: 63-117.

1944. Nature and degree of recovery of grassland from the great drought of 1933 to 1940 . Ecol. Monog. 14: $393-479$. 
Weaver, J. E., \& W. E. Bruner. 1945. A seven-year quantitative study of succession in grassland. Ecol. Monog. 15: 297-319.

Weaver, J. E., \& R. W. Darland. 1947. A method of measuring vigor of range grasses. Ecology 28: 146162.

1948. Changes in vegetation and production of forage resulting from grazing lowland prairie. Ecology 29: 1-29.
Weaver, J. E., \& T. J. Fitzpatrick. 1934. The Prairie. Ecol. Monog. 4 : 109-294.

Weaver, J. E., \& W. W. Hansen. 1939. Increase of Sporobolus cryptandrus in pastures of eastern $\mathrm{Ne}$ braska. Ecology 20: 374-381.

1941. Native midwestern pastures; their origin, composition, and degeneration. Univ. Neb. Conserv. and Surv. Div. Bul. 22 